\title{
Rosicrucianism Praised: The Early Response
}

The Rosicrucian manifestos were clearly mission statements, promising the reform of divine and worldly matters, and their readers were invited to join the Rosicrucian cause. But the texts did not outline a precise programme of how the world and the divine should be transformed or how people could contribute to the improvement of all aspects of life. The absence of such a programme might have contributed to the texts' appeal, as it gave readers the opportunity to develop and express their own interpretations. The manifestos' unorthodox message and optimistic tone, fuelled by the use of well-known apocalyptic themes, stirred up a very strong response in the years immediately after their publication. ${ }^{1}$ As was observed by Andreae, hundreds of authors responded to these provocative texts, proclaimed themselves to be Rosicrucian prophets, emphatically defended the Rosicrucian cause, or hoped passionately one day soon to become members of the Rosicrucian brotherhood. With such a flood of written responses-over 400 within the first decade after the publication of the manifestos - this episode can aptly be characterised as the "Rosicrucian furore."

But why exactly did these texts cause such an uproar? What ideas aroused the interest of their readers, and which themes were featured in the earliest replies to them? More specifically, to what extent did the ideas associated with the announced general reformation play a role in the initial Rosicrucian turmoil? As the earliest reactions differed substantially from each other, there is no simple and straightforward answer to these questions. Some authors made it their mission to describe to their readers the Rosicrucian fraternity, its location, and its structure. A case in point is Raphael Eglin (1559-1622), theologian, alchemist, and student of the Italian philosopher Giordano Bruno (1548-1600). Eglin worked at the court of Moritz in Kassel, where the manifestos had been published, and is thought to have been the author of a poem entitled Assertion of the Fraternity (1614). ${ }^{2}$ He posed as a brother of the Rosicrucians, but kept his name secret, signing the text only with the initials B.M.I. ${ }^{3}$ In response to widely

1 For an overview, see: Gilly, Cimelia Rhodostaurotica.

2 Strieder (1783) presents Eglin as the publisher of the Assertio: Strieder, Grundlage zu einer Hessischen Gelehrten und Schriftsteller, vol. 3, 316.

3 On Eglin as the poem's probable author, see: Gilly, Cimelia Rhodostaurotica, 89. On Eglin, see: 
expressed doubts about the fraternity, he affirmed its existence, alluded to the brethren's secret arts and studies, and described their habitat as a monastery hidden in a wooded area in central Germany. ${ }^{4}$

Faced with the danger of prosecution and the risk of losing their professions, many Rosicrucian enthusiasts concealed their true identity. A few years later, in 1618, Eglin's poem was followed by another pseudonymous text, published under the name of Anastasius Philaretus Cosmopolita. This letter can now be traced back to Joachim Morsius (1593-1643). ${ }^{5}$ The short text was meant to describe how Morsius himself became acquainted with the Rosicrucians, and how their manifestos had brought him "from wandering shrouded in darkness on my narrow ways" to the path of truth. ${ }^{6}$ Morsius was related to the well-known Rosicrucian adept Adam Haslmayr (1562-ca. 1631), because he was the author of the Nuncius Olympicus (Heavenly Herald, 1626). This text was a catalogue of 228 writings from a "secret library," which we now know was Haslmayr's, and which included 16o works written by Haslmayr himself.7

Equally inspired by the Rosicrucian message was the engraver Michel le Blon (1587-1657), who was born in Germany of Dutch parents and who lived in the Netherlands during his adult life. There he met the painter Torrentius, whom we briefly encountered in Chapter One and who was suspected of belonging to the Rosicrucian brotherhood. So impressed was Le Blon by the manifestos' description of the Rosicrucian fraternity that he immediately wrote a reply to these laudable writings and instantly sought to join the brotherhood. ${ }^{8}$

These replies, like many others, show how enthralled many early modern readers were by this secret fraternity and what it represented, but they did not discuss the contents of the manifestos. The enthusiasm of these proponents was shared by others who, by contrast, aimed to explain the Rosicrucian philosophy and the fraternity's objectives. This was the case for Morsius' colleague

Moran, "Alchemy, Prophecy, and the Rosicrucians. Raphael Eglinus and Mystical Currents of the Early 17th Century"; Hotson, Johann Heinrich Alsted, 59-65, 98-103.

4 B.M.I. [Eglin?], Assertio fraternitatis, $2^{\mathrm{r}}-4^{\mathrm{v}}$.

5 On Morsius, see: Schneider, Joachim Morsius und sein Kreis; Schick, Das ältere Rosenkreuzertum, 189-192; Gilly, "Iter Rosicrucianum," 65, 73-75; Hotson, Johann Heinrich Alsted, 102, 119$120,144,155$.

6 Anastasius Philareti Cosmopolitae, Epistola sapientissimae F.R.C. remissa, A2-A3: "Unicum hocce tantum restat, uti quo queam ab erroneis tenebricosis meis semitis abduci, inquit lucidissimam veritatis regiam viam reduci [...]."

7 For the text, see: Gilly, Adam Haslmayr, 241-29o. See further: ibid., 23-25, 239; idem, "Iter Rosicrucianum," 73-75; Åkerman, "The Rosicrucians," 2; eadem, "Paracelsianism in Sweden," 428.

8 Michel le Blon, Antwort oder Sendbrief; Gilly, Cimelia Rhodostaurotica, 91. On Torrentius, see below, section $5 \cdot 3$. 
Haslmayr, as well as for Michael Maier (1568-1622), the pseudonymous Julianus de Campis, Daniel Mögling (1596-1635), and several anonymous authors. Unlike many others, these authors offered an interpretation of the message, mission, and philosophy of the brethren. While several of these key figures have been discussed by the Rosicrucian scholarship, others have only briefly been touched upon, and their responses to the manifestos are yet to receive careful and detailed analysis. ${ }^{9}$ Whereas historiography on the early optimistic response has largely attempted to sketch the Rosicrucian furore, ${ }^{10}$ this chapter takes again a different approach: it will not discuss the early response in general terms or in the context of authorship, but it will analyse the response from the specific perspective of the theme of a general reformation. In so doing, it aims to address and explain the main appeal of the manifestos in the early seventeenth century.

Each of the key figures discussed in this chapter was well-known in the years after the first publication of the manifestos. Haslmayr's Answer was published together with several editions of the Fama, and his name appeared on the title page of later editions of this manifesto. Maier was a renowned alchemist who worked as court physician to Rudolph II in Prague and who defended the Rosicrucians on several occasions. Julianus de Campis attracted attention because also his reply was published in an edition of the manifestos. ${ }^{11}$ And Mögling, finally, was acquainted with well-established figures such as Johannes Kepler and the engraver Matthaeus Merian the Elder (1593-1650),

9 Gilly, for example, discusses Haslmayr at great length, but especially focuses on his context and includes many of his manuscript texts. We will instead analyse in detail his published response to the manifestos: Gilly, Adam Haslmayr. Julianus is only touched upon in: Schick, Das ältere Rosenkreuzertum, 238-245; Peuckert, Das Rosenkreuz, 5, 115, 124, 148, 157; Gilly, "Las novas." Mögling, his life, and his ideas have been discussed at greater length in general terms, but his texts in defence of the manifestos still require in-depth discussions; see especially: Van Dülmen, "Daniel Mögling”; Neumann, “Olim, da die Rosen Creutzerey noch florirt." The anonymous authors have only briefly been referred to twice: Schick, Das ältere Rosenkreuzertum, 168-169; Peuckert, Das Rosenkreuz, 100-101, 103, 110. Maier has been studied extensively, but here we will focus on his ideas of reform in relation to the Rosicrucian manifestos, specifically. On Maier, see especially: Tilton, The Quest for the Phoenix; Nummedal (ed.), Furnace and Fugue.

10 See, for example: Peuckert, Die Rosenkreuzer; idem, Das Rosenkreutz; Schick, Das ältere Rosenkreuzertum; Van Dülmen, "Daniel Mögling. 'Pansoph und Rosenkreuzer'”; Yates, The Rosicrucian Enlightenment; De Jong, "The Chymical Wedding”; Edighoffer, Les Rose-Croix; McIntosh, The Rosicrucians; Åkerman, Rose Cross over the Baltic; eadem, "The Rosicrucians and the Great Conjuntions"; Gilly, Johann Valentin Andreae; idem, "Iter Rosicrucianum"; idem, "Campanella and the Rosicrucians"; Snoek, De Rozenkruisers.

11 Julianus de Campis, Sendbrieff oder Bericht, appended to: Fama Fraternitatis (Frankfurt am Main, 1615). 
and his works circulated widely in early modern German regions. ${ }^{12}$ The images included in his texts still grace the covers of some recently published books. A similar fate befell the four anonymous replies that were published together with the German edition of the Confessio: thanks to the prominent place of publication they reached a wide audience, not least because the earlier edition of the Fama had made people aware of and sensitive to the Rosicrucian cause. Some of the above-mentioned authors also moved in circles close to the presumed authors of the manifestos: Haslmayr, the first responder to the Fama, must have known of Andreae through Figulus, while Julianus and Mögling lived in Tübingen and were acquainted with Hess and Andreae. ${ }^{13}$

But the responses, even of those who addressed the brethren's intentions and contributions, were anything but homogeneous. The Rosicrucian message was explained through, integrated into, and sometimes adapted to each author's own theological and philosophical worldview, and this gave rise to a variety of unique, innovative, and occasionally enigmatic interpretations of the Rosicrucian cause. In some replies, the Rosicrucian manifestos were explicitly associated with Paracelsus and Paracelsianism. Paracelsus even came to be seen as the father of the so-called "Theophrastia Sancta," a label referring to a religious interpretation of the writings of Theophrastus Paracelsus. ${ }^{14}$ Other authors put the emphasis on the apocalyptic nature of the manifestos or emphasised their alchemical connotations. Again others read the manifestos as messengers provoking religious, academic, philosophical, and scientific transformations. Finally, some authors were particularly inspired by the religious implications of the manifestos, and linked the Rosicrucian texts to theosophy. This chapter will analyse and discuss the responses of these authors to the Rosicrucian manifestos in order to establish how they interpreted the Rosicrucian message and what part the call for a general reformation played in their respective replies.

\subsection{Avoiding Tribulations: The First Response to the Fama}

The first response to the Fama Fraternitatis came from the hand of the Paracelsian adept Adam Haslmayr, whose Answer to the Laudable Brotherhood of the Theosophers of Rosencreutz was printed as early as 1612, two years before the

\footnotetext{
12 Van Dülmen, "Daniel Mögling," 44; Neumann, "Olim, da die Rosen Creutzerey noch florirt," 105 .

13 On Julianus' identity, see below, section 4.4.

14 On the "Theophrastia Sancta," see below, pp. 239-240.
} 


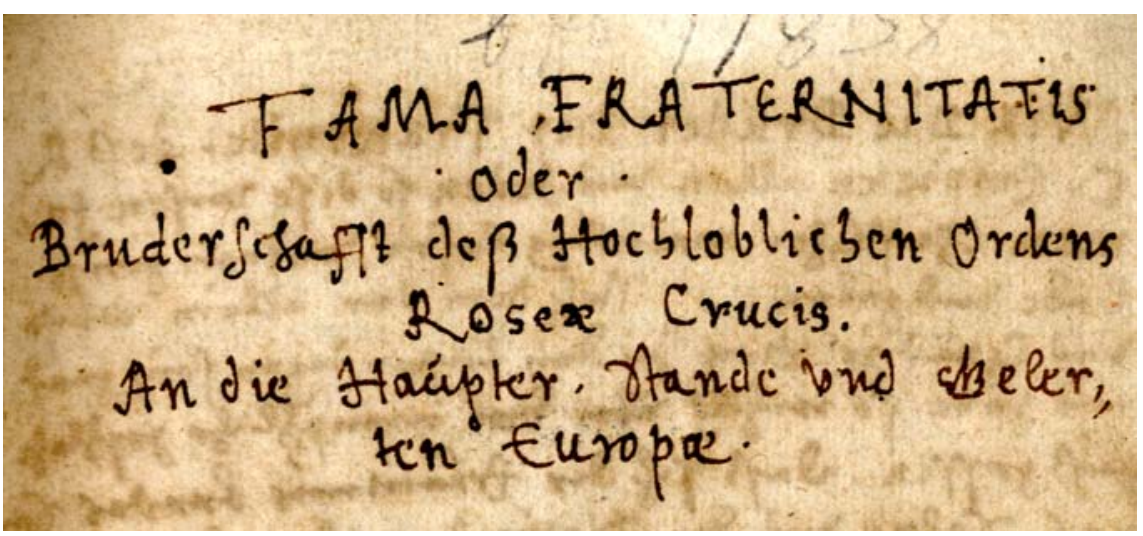

FIGURE 8 Fama fraternitatis, manuscript version from Besold's library, Universitätsbibliothek Salzburg

publication of the Fama itself. ${ }^{15}$ It was republished together with the first edition of the Fama in 1614, and in following years with several editions and translations of the Fama and Confessio. In the title of his text, Haslmayr referred to the "theosophers of Rosencreutz." Of the surviving manuscript versions of the Fama written before Haslmayr's Answer, only the edition kept in Salzburg refers to Rosencreutz by his full name. One of the London manuscripts (MS 310 ) refers only to "R.C." throughout the text, while the other manuscript in London (MS 150) and the manuscript in Wolfenbüttel were written after $1612 .{ }^{16}$ Published versions of the Fama and the Confessio, with titles giving Rosencreutz's name, were naturally not yet in circulation. This means that when Haslmayr wrote his Answer, the name "Rosencreutz" had not been publicly communicated in the surviving documents except for the Salzburg version, which came from Besold's library. This suggests that Haslmayr had access to either Besold's version of the Fama, from which unfortunately several folios are missing, or to a now missing manuscript version related to it. ${ }^{17}$

15 Adam Haslmayr, Antwort An die lobwürdige Brüderschafft der Theosophen von RosenCreutz N.N. On Adam Haslmayr, see: Senn, "Adam Haslmayr-Musiker, Philosoph, und 'Ketzer'"; Gilly, Adam Haslmayr; idem, Cimelia Rhodostaurotica, 29-41; idem, "'Theophrastia Sancta"; Murase, "Paracelsismus und Chiliasmus," 215-227. Senn's analysis is at times corrected by Gilly. Here, the facsimile edition of the Antwort in Gilly's Adam Haslmayr will be used.

16 Cf. Gilly, Cimelia Rhodostaurotica, 27-28.

17 Fama Fraternitatis, Herzog August Bibliothek (Wolfenbüttel), Cod. Guelf. 39.7 Aug 20 fols. $365^{\mathrm{r}}-374^{\mathrm{r}}$; Universitätsbibliothek Salzburg, MS M I 463, fols. $1^{\mathrm{r}}-13^{\mathrm{r}}$; Wellcome Library, MS 15 o fols. $129^{\mathrm{r}}-139^{\mathrm{r}}$; Wellcome Library, MS 310 fols. $245^{\mathrm{r}}-264^{\mathrm{v}}$. On the early circulation of the Confessio, see below, p. 248 . 
In order to situate this author in the early diffusion of the Rosicrucian ideas, we need to know something about his life. Haslmayr was born in the South Tyrolean city of Bolzano (in modern-day Italy) on $3^{1}$ October $1562 .{ }^{18}$ From 1588 onwards, he worked as a teacher of Latin. ${ }^{19}$ Around the same time, he received a copy of the Paracelsian Philosophia Sagax (or Great Astronomy) from a friend named Lorenz Lutz, but the beginning of his documented interest in Paracelsianism dates from $1594 .{ }^{20}$ He became closely related to the alchemist and Paracelsian physician Karl Widemann (1555-1637), who copied Paracelsian, Weigelian, and magical manuscripts, ${ }^{21}$ and with whom Haslmayr shared a house for a couple of years. While living in the Tyrolean city of Schwaz, he was surrounded by alchemists and Paracelsian physicians. There he met Benedictus Figulus (Benedict Töpfer, 1567-after 1619) in 1607, who was presumably responsible for the early distribution of the Fama, and with whom Haslmayr co-authored several writings. ${ }^{22}$

Widemann had invited Prince August von Anhalt-Plötzkau (1575-1653), who was equally inspired by Paracelsian and mystical writings, to publish works by Paracelsus and the medieval mystics Johannes Tauler and Meister Eckhart (126o-1328), as well as "theological manuscripts [...] against the errors and mistakes of the papists, Lutherans, and Calvinists" - a request that August declined, considering the enterprise too dangerous. ${ }^{23}$ In 1611, Widemann introduced Haslmayr by letter to Prince August, after which the three men studied heterodox texts together. They started searching for the Rosicrucians in the same year, and are thought to have run a secret printing press in which they

18 In his Adam Haslmayr, Gilly suggests that Haslmayr was born around 1560, but he revised this in his Cimelia Rhodostaurotica, where he dates Haslmayr's birth to $3_{1}$ October 1562; see: Gilly, Adam Haslmayr, 32; idem, Cimelia Rhodostaurotica, 3 .

19 Gilly, Adam Haslmayr, 32-33.

20 Idem, Cimelia Rhodostaurotica, 30. According to Widemann, Lutz had been personally acquainted with Paracelsus: "Lorentz Lutz, burger von Baden im Algeu dt 1/4 Meil von Meron im Etschland. Obiit. Diser hat Theophrastum selber khenndt”: Widemann, Sylva scientiarum, Hannover, Niedersächsische Ländesbibliothek, MS IV, 341, fols. 314-316, cited in: Gilly, Johann Valentin Andreae, 48.

21 Idem, Adam Haslmayr, 106-107.

22 Idem, Cimelia Rhodostaurotica, 38.

23 "Manuscripta Theologica [...] wider die Irrtumb und fähler der Papisten, Luttrischen, Calvinischen [...]," cited in: Gilly, Adam Haslmayr, 110. The terms "mystic" and "mystical" refer to a tradition which is characterised by a study of God, a quest for unity with the divine, and in general by the purification and perfection of the individual human being through non-physical means. On mysticism, see also: Rousse-Lacordaire, "Mysticism," in: Hanegraaff (ed.), Dictionary of Gnosis and Western Esotericism, 818-820. 
printed Paracelsian and Weigelian texts. ${ }^{24}$ Irrespective of whether or not printed books actually did fly off their presumed press, they considered it their task to disseminate the ideas contained in these elusive writings and to spread their message of promise and hope. They mixed Paracelsianism with mystical thought and, later, with Rosicrucianism, and their ideas found their way through subterraneous mazes to readers across Germany. ${ }^{25}$

Haslmayr wrote prolifically on Paracelsian, mystical, and heterodox concepts, and between 1605 and 1630 his output amounted to almost 200 texts. ${ }^{26}$ His fervour to make his ideas public, as well as the unfortunate fate that befell him as a result, is apparent from several events in his life. Convinced by his Paracelsian and Rosicrucian ideas and eager to communicate them, he sent several Paracelsian writings as well as letters in which he preached about the Rosicrucians to Maximilian III (1558-1618), who at the time was governor of Tyrol (1602-1612) and later Archduke of Austria (1612-1618). Haslmayr either expected the governor to be interested in Paracelsian and Rosicrucian ideas, or else he wanted to persuade Maximilian to adopt the mantle of ruler over the End Times. His appeals, however urgent they may have been, fell on deaf ears. On several occasions, the governor had Haslmayr searched and investigated for his heterodox views: first in 1603, after he had sent letters containing Paracelsian notions to Maximilian, and again in 1612 after Haslmayr had sent a series of letters about the Rosicrucians. ${ }^{27}$

The final episode was preceded by direct and indirect attacks from one of Haslmayr's opponents, the Jesuit protector Hippolytus Guarinoni (1571-1654), a Galenic physician who originally came from Tyrol but was educated by the Jesuits in Prague. Guarinoni criticised Paracelsian doctors, including Haslmayr, and was determined to discredit him in the eyes of the authorities. In this, he proved to be successful. Haslmayr replied to Guarinoni in his Apology of 1611, which was dedicated to Maximilian III. Haslmayr had always spoken highly of the governor in his letters, and seems to have had complete confidence in the latter's intentions and possible Rosicrucian dispositions. He was in for a disappointment. In January 1612, Guarinoni warned the government about Haslmayr, after which, on 8 February 1612, an investigation was conducted

24 August confessed to owning this press in a letter to Widemann; see: Widemann, Sylva scientiarum, Niedersächsische Landesbibliothek Hannover, MS IV 341, fol. 544, cited in Gilly, "Iter Rosicrucianum," 76. On the early contacts between Widemann, August von Anhalt, and Haslmayr and their search for the Rosicrucians, see: Gilly, Adam Haslmayr, 118-145; idem, "Theophrastia Sancta."

25 Gilly, "Theophrastia Sancta," 18o.

26 Ibid., 168.

27 Gilly, Adam Haslmayr, 35, 47-56. 
against him, and a letter was sent by the government to the local authorities in Schwaz that ordered his books to be investigated and suspicious texts to be confiscated. ${ }^{28}$

Haslmayr, apparently unperturbed by these warning signs, delivered his Modest Advisory Letter of Insignificant Origin to the court chancellor on 21 August 1612. He must have been unaware of the secret arrest warrant of 1 August 1612 as a response to his letters, in which Maximilian named Haslmayr's "evil heretical opinions," "damaging views," and his "poisonous evil writings" as reasons for his conviction. ${ }^{29}$ In his Advisory Letter, Haslmayr communicated his expectation that the Rosicrucians could be found in Montpellier, andinspired as he was by such promising men-he hoped for Maximilian's financial support to search for the brethren. His appeals were not well received. Upon delivering the text, Haslmayr was arrested and imprisoned. Although Maximilian released him for a short period, when the letter did eventually reach the governor in December 1612, the heterodox thinker was sent, not to Montpellier, but instead to enforced labour on the galleys departing from Genoa. There, Haslmayr worked as a slave until mid-1617, when he was released at the age of $55 \cdot{ }^{30} \mathrm{His}$ time on the galleys was miserable, but even while chained he occasionally had access to ink and paper. He concluded a letter sent to Widemann with the words: "in the year IVDICIVM [1613], given on the New Year on the S. George galley in Genoa, written in a rush on my knees, filled with grief." 31

That these were terrible times for this aspiring Rosicrucian is clear from his Description of the Terrifying Life, a text written in 1622 that also deals extensively

28 "Derenthalben so ist in der Fürstl. Durchlaucht Erzherzog Maximiliani [...] unseres gnedigsten Herrn, namen unser bevelch an Euch, das Ir nit allein alspaldt und ohne einstellen, obgedachten Haßlmayr und Götschl (da anderst der Infection halber khain gefahr darbey zubesorgen) in Iren Wonnungen im gehaimb und unvermerckht uberfallet, Ire Püecher mit fleis durchsehet, und da Ir bey einem oder dem anderen, was verdächtigs befunden, alßdan dise zestund an zu Euwern hennden nemet, in ain Peützel einschläget, und uns volgendts solliche unverzegenlich hieher zu unnsern der Regierung hennden uberschickhet, sonder auch Ires thuens, lassens, und verhaltens, da Irs zuvor nit wissens hettet, mit fleis erkhündiget [...]. Datum den 8. Tag Februarii Anno 1612," cited in Gilly, Adam Haslmayr, 45 .

29 Gilly, Adam Haslmayr, 6o: "bese khetzerische Opinionen," "schedliche Meinungen," "gifftige böse Schrifften."

30 Gilly, Adam Haslmayr, 55-58; idem, Cimelia Rhodostaurotica, 33 .

31 Gilly, Adam Haslmayr, 58: "anno IVDICIVM / geben zum Neüen Jahr auff S. Georgen Galern zue Genua inn eill auff den knien voll Trüebsall geschrieben." IVDicivm is the year of judgement according to Haslmayr, and refers to the year MDCVVIII = 1613; see below, p. 224 . 
with Paracelsus' Philosophia Sagax. ${ }^{32}$ When he first arrived in Genoa, Haslmayr recalls, his clothes were taken away from him, his beard and hair were shaved, and he was chained to the galleys. ${ }^{33} \mathrm{He}$ rowed the ships to numerous places and, when recounting his horrors, explained that "what kind of restless, wild, improper, desperate, sodomic life has been led on the galleys, especially by the Welsh [French and Italian] prisoners, is therefore not to be described for chaste ears." ${ }^{34}$ Even though his hopes for the archduke's support had vanished, Haslmayr did not abstain from writing further theosophical and Paracelsian texts and promoting the Rosicrucians. ${ }^{35}$

Haslmayr's Answer, which had not been confiscated by the authorities and was therefore apparently not the reason for his imprisonment, provides much insight into the earliest phase of the Rosicrucian furore as the first response to the manifestos. ${ }^{36}$ August von Anhalt, who had received Haslmayr's Answer, may have been responsible for its publication, as the text was presumably issued from his secret press. ${ }^{37}$ Only one copy of the original publication survived until 2004, when the library in Weimar caught fire and Haslmayr's Answer was lost in the flames. Fortunately, Carlos Gilly had previously included a facsimile edition of the text in his Adam Haslmayr.

\section{Apocalyptic Changes}

The Fama had been circulating in manuscript form as early as 1610, the year in which Haslmayr first read the manifesto in his home region, Tyrol. So enthralled was he by its contents that no sooner had he finished studying the manifesto than he began to work on his particularly cryptic Answer to its authors. Haslmayr, a deeply religious person, studded his reply with references to religious episodes and biblical passages, and staged it in the context of apocalyptic events announced in Scripture. Although he was a Paracelsian physician, he

32 Haslmayr, Beschreibung des erschrecklichen Lebens, Niedersächsisches Staatsarchiv Wolfenbüttel, 1 Alt 22 , nr. 226 , fols. $227^{\mathrm{r}}-23^{\mathrm{r}}$. Many parts of the text are illegible due to water damage.

33 Ibid.

34 Ibid.: "Was aber für ein Ruehloß, whuestes, ungeheurigs, verzweifeltes, Sodomitisches Leben auf den Galern, von den Welschen Gefangnen sonderlich, ist gefhiert worden, ist daher wegen der keuschen ohren nicht zu schreiben," cited in: Gilly, Cimelia Rhodostaurotica, 34 .

35 Unfortunately, most of these writings are currently lost.

36 At an earlier stage of Gilly's career, in his chapter on the "Theophrastia Sancta," he explained that Haslmayr's Antwort was what led him to the galleys, but in later works he shows instead that his many letters to Maximilian provoked the suspicion of the authorities; see: Gilly, Adam Haslmayr, 40-6o; idem, Cimelia Rhodostaurotica, 33-34. 
was not primarily responding to the brethren's medicine or the Paracelsian natural-philosophical references contained in the Fama. Instead, he took the manifesto as a warning about the world's imminent end. While the Fama was optimistic in nature, Haslmayr's Answer was decidedly pessimistic. He was convinced that his days were the last before the world's end, and he made it his task to forewarn his readers and to suggest they take the Rosicrucian messages to heart: "Therefore we now also do not have any certain minutes left, when God will come with punishment, unforeseen as over Sodom."38 Just as in Sodom, corruption and wickedness were abounding - and the expectation was that God would soon intervene and give vent to His wrath.

To announce the imminence of the Last Judgement, he used two anagrams, IVDICVM and IVDICIVM. These anagrams signal his dismay over present times, because they "demonstrate thus that we will not have anyone who will assist us, on whom we may be able to rely."39 Disheartened as he was over the condition of the world, Haslmayr believed the final times to be characterised by abysmal hardship. IVDICVM, or iudicum, is Latin for "of the judges," but Haslmayr also saw it as a number symbol from the Roman year numbering MDCVVII, a variant of MDCXII, and thus the year 1612. IVDICIVM, by contrast, is Latin for "Judgement," which can be understood as an anagrammatic representation of MDCVVIII (M DCXIII), 1613. In Haslmayr's sentence, "IVDICVM" and "IVDICIVM" thus refer also to 1612 and 1613 , respectively, and indicate the years when the judges will come and the Judgement would be pronounced. In the Answer appended to the Dutch translation of the Fama (Jan Berner, 1615), the words "IVDICVM" and "IVDICIVM" were directly translated to "judges" and "judgement" with, as superscripts, the numbers "1612" and "1613," respectively.40 Later, in his letter to Widemann from the galleys, Haslmayr would indeed explicitly refer to "the year IVDICIVM," which was the year 1613 .

His rewriting of these Roman year numbers was no doubt done intentionally, as he expected the "Judge" to come and "impose destruction in this year 1612," and that the Final Judgement would follow shortly afterwards $(1613) \cdot{ }^{41}$

38 Haslmayr, Antwort, Aiiir: "Daher haben wir nun auch kein sichere Minuten mehr/ wann Gott kommen werde mit straff/ wie uber Sodoma unversehens." For the destruction of Sodom and Gomorrah, see: Genesis 10:19; 13:10, 14; 18-19.

39 Haslmayr, Antwort, Bv: "IVDICVM und IVDICIVM zeygen uns dermassen/ das wir keinen werden haben der uns beystehnt wirt/ auff den wir uns verlassen möchten."

$40 \quad$ Fama Fraternitatis, oft Ontdeckinge van de Broederschap des loflijcken Ordens des RoosenCruyces, $\mathrm{D}_{7}^{\mathrm{r}}$.

41 Haslmayr, Antwort, Bv: "In dem sich diß 1612 Jar/ der Richter undergang erhebt/ zum anfang der schmerzen [...]." 
Given that his Answer was written in 1612, the year of the final tribulations, the sense of urgency and distress is understandable. For Haslmayr, because there was neither time nor hope left for earthly improvement, the general reformation as envisioned and called for in the manifestos could not take place. He seems to have understood the Fama exclusively as a message about the imminent end rather than as an admonition to transform the world. In this regard, he found himself in the vicinity of both Luther's and Paracelsus' religious writings, hoping for imminent liberation from worldly misery.

But not all elements of the general reformation were lost in the Answer, and most of them played a prominent role in Haslmayr's alternative reading of the Fama. In his Answer, he specifically referred to the pseudo-Paracelsian lion prophecy. The prophecy itself had been drafted around 1600 and had influenced the Rosicrucian authors, but it was not published until the 1620s. By the time of Haslmayr's response, the Confessio, which included references to the lion, had not yet been published, which made Haslmayr the first to publicly refer to the Midnight Lion as announced in the pseudo-Paracelsian prophecy. ${ }^{42} \mathrm{He}$ described the lion as a saviour who could rescue the people from the destruction caused by the "enemy of Christ." Haslmayr explains that the latter, the Antichrist, in keeping with the Apocalypse, will come "with his Babylonian cavalry and courtiers," and "bring great ruin." ${ }^{33}$ The Confessio was later to identify the Antichrist with the pope, but Haslmayr, a Catholic, when writing his Answer was still hoping to win the Catholic governor Maximilian over to his cause. He presumably did not want to offend his governor with attacks on the Supreme Pontiff. For him, the "false Christ" was simply the biblical apocalyptic figure of the Endchrist, without any confessional connotations. During these Last Days, the false Christ "will show himself as if he had won, and as if life has ended with us," that is, as if the world was to end under his rule. But God will intervene, Haslmayr believed, as He "will mortally destroy and exterminate" the false Christ through "the small flock." ${ }^{4}$ With the latter term, Haslmayr

42 On this prophecy and its manuscript versions and published editions, see: Pfister and Schmidt-Tieme, "Der Löwe aus Mitternacht." See also above, section 1.1. Haslmayr included this prophecy in: Widemann, Sylva scientiarum, Hannover, Niedersächsische Ländesbibliothek, MS IV, 341, fol. 689. On Haslmayr as the first to refer to the prophecy, see Gilly, Adam Haslmayr, 85 .

43 Haslmayr, Antwort, Aiiiv-Aiiiir : "Auff solches wirdt der Feindt Christi (das ist der hoffertig falsche Christ/ sampt seiner Babilonischen Reutterey und hoffhaltung) sich mechtig empor erzeygen/ unnd groß verderben bringen."

44 Ibid., Aiiiv-Aiiiir: “[...] unnd [er] wirdt sich sehen lassen/ samb hab er gewunnen/ unnd mit uns das Leben auß sey/ so wirdt ihn aber Gott in seinem grösten Glück/ durch das 
was referring to the Rosicrucians, whom he believed were God's helpers during these Final Days. ${ }^{45}$ For Haslmayr, God was not only to be feared for his possible punishment, but He was also understood as the final liberator.

Here, Haslmayr was not simply borrowing from the traditional understanding of the End Times, according to which the Antichrist will be defeated by divine intervention, because he attributed to the Rosicrucians this central historical task: they will ultimately be the agents defeating the enemy. But they will be "preceded by the Midnight Lion," who will "rush up to the cruel enemy" first. ${ }^{46}$ Haslmayr clearly identified the lion with the personage from the Paracelsian prophecy, but for him this preliminary hero would come in the end to prepare for God's, or rather the brethren's, destruction of the Antichrist. The lion was not understood as a Last World Emperor, and he was therefore different from the Rosicrucian lion for the future age who was to defeat the Antichrist and rule over a future realm.

Although the lion had been announced in earlier prophecies, and the pseudo-Paracelsian prophecy circulated widely in manuscript form, no early modern ruler had yet claimed or taken up its role. Only during the Thirty Years' War would rulers be identified, or identify themselves, as the lion of the prophecy. It was often used for Protestant political propaganda, first in relation to Frederick $v$ of the Palatinate (1596-1632), but later, after Frederick's demise at the Battle of the White Mountain in 1620, in support of Gustav Adolf of Sweden (1594-1632), who was supposed to save Europe from the invasion of the Catholic Habsburgs. In 1630 and 1631 alone, the prophecy was reprinted over twenty times. Gustav Adolf readily took on this role, and ordered medals to be produced depicting himself on one side and the Midnight Lion on the other. ${ }^{47}$

Years earlier, in 1612, Haslmayr had already witnessed the increasing religious tensions that ultimately led to this calamitous war. He implored the notably Reformed August von Anhalt to take the role of Midnight Lion upon himself. August, after all, had long demonstrated his desire to disseminate the true teaching. Given the lack of another suitable candidate, Haslmayr deemed the Prince the right person for the task. August however declined, believing that such a position would inevitably involve the use of violence. ${ }^{48}$ The fact that

kleine Heuflein/ (welchen der Löw von Mitternacht vorgehn wirdt/ den grausamen Feindt zustürzen) sterblich verdilgen/ und außrotten/ doch sollen viel an seinen Namen glauben/ Haec ille."

Ibid., Aiiii".

46 Ibid., Aiiii ${ }^{\mathrm{v}}$-Aiiiir; see n. 44.

47 Sudhoff, Versuch einer Kritik, 322, 330, 338-354; Åkerman, Rose Cross, 162-163. Cf. Hotson, Paradise Postponed, 61.

48 Gilly, Adam Haslmayr, 89-9o. 
Haslmayr believed the Reformed August and not the Catholic Maximilian to be the right person for the task is striking, and gives the impression that, for Haslmayr, the lion would be called upon to play a supra-confessional role during the End Times.

This alludes to another element that was used by the authors of the manifestos in their call for a general reformation, but that was ably adjusted by Haslmayr: apocalyptic revelations. Haslmayr's lion was not only the attacker of the Antichrist but also an apocalyptic figure in the strict sense of the word, as he would disclose divine mysteries during the Final Times. The pseudoParacelsian lion prophecy had not only referred to the figure of the lion, but also to three treasures that were hidden throughout Europe. These treasures were later to be mentioned also in the Confessio as foundational treasures for the lion's new realm. Haslmayr explained that Paracelsus had "hid away his treasures" to protect them from greedy and bloodthirsty people, ${ }^{49}$ but that they were to be rediscovered. Once more he expressed his belief that in the year of writing his Answer the world would undergo radical transformations, because the "three treasures shall be found shortly after the death of the last Austrian Emperor Rudolph." ${ }^{50}$ This is a reference to Rudolph II (1552-1612), Holy Roman Emperor from 1576 until 1612, who died in January of the year that Haslmayr wrote his Answer.

Rudolph II, at whose court Haslmayr's close friend Widemann had stayed, supported scholars working on magical and occult sciences. ${ }^{51}$ The apocalyptic sense is evident: the death of this guardian of the arts and sciences constituted for Haslmayr an important episode of the End Times. Thanks to the rediscovery of the three treasures, the Rosicrucians were to "illuminate the way for the Midnight Lion, who is rich in Christian teaching, in the light of Christ and the sanctuary of nature, so that the impure, imperfect, and diabolical [teachings] of the pagan masters will be entirely revealed and rebutted."52 This new

49 Haslmayr, Antwort, Aiiiir: "daher auch gemelter Theophrastus seine Thesauros, den Geltgeyzigen unnd Blutgirigen Volck verborgen/ biß auff die Zeyt/ da die kommen sollen/ die das Gelt nicht achten." Cf. ibid., Aiiiv.

50 Ibid., Aiiiiv: "Unnd die obgemelte Prophetia Theophrasti auch meldet/ wie das seine 3. Schätz bald nach abgang deß lesten Osterreichischen Keysers Rudolphi/ sollen gefunden werden/ die dörfftigen dardurch zu erhalten."

51 Cf. Evans, Rudolph II and his World.

$5^{2}$ Haslmayr, Antwort, Bv -Biir: "so kompt [...] dem Leoni von Mitternacht/ der voller Christlicher Lehr ist/ vorzu leuchten/ im Liecht Christi/ und der Natur Heyligthumb auff das das impurum, imperfectum, diabolicum der Heydnischen Meyster ganz reueliert und confundiert werde (1Cor. 1)." 1 Corinthians 1:19-23: "For it is written, I will destroy the wisdom of the wise, and will bring to nothing the understanding of the prudent. Where is the wise? 
Christian ruler should overrule the pagan masters in the end and replace their studies with Christian secrets and natural treasures, making these treasures apocalyptically relevant. The lion, as in the manifestos, had both a political significance (in the person of August von Anhalt) as well as a spiritual, or philosophical, role.

As the harbinger of wisdom, the lion was similar to the prophet Elijah. It was a common belief, based on passages such as Daniel 12, Acts 2, and Joel 2:28-29, that in the Final Times God's mysteries and wisdom would be revealed by Elijah. Haslmayr, unlike the Fama, borrowed from the early Paracelsians and awaited Elijah's early modern derivative, the apocalyptic, alchemical, and medical figure Elias Artista. ${ }^{53}$ The brethren, according to him, revealed their secrets on the eve of Elias' arrival: "So we sense and conclude, that you are now the ones chosen by God, who will amplify the eternal Theophrastian and divine truth, miraculously preserved until now, possibly to heed the times of the foretold Elias Artista. ${ }^{54}$ By referring to Elias Artista, Haslmayr showed his proximity to early Paracelsians and their call for medical and alchemical change.

The pagan masters cited in the quote above hint at another element of the Rosicrucian general reformation that was appropriated by Haslmayr to his own apocalyptic scheme. According to him, hidden wisdom will resurface at the expense of established learning, because together with the three treasures will lie "the true liberal and unheard-of books on the arts, hitherto unthought of by the children of man." ${ }^{55}$ His reference was to the liberal arts of the universities, but the true liberal arts to be discovered were not practised by academic scholars. Haslmayr readily agreed with the Paracelsian rejection of "pagan" knowledge, with the novatores of the early modern period, and with many others supporting the Rosicrucians who believed that university teaching and practices were to be replaced. He exclaimed: "But how desperate and unfortunate is the hour in which the happiness is denied to us, and in which we are bid by

Where is the scribe? Where is the disputer of this world? Hath not God made foolish the wisdom of this world? For after that in the wisdom of God the world by wisdom knew not God, it pleased God by the foolishness of preaching to save them that believe. For the Jews require a sign, and the Greek seek after wisdom: But we preach of Christ crucified, unto the Jews a stumblingblock, and unto the Greeks foolishness."

53 On Elijah and Elias Artista, see above, p. $123 \mathrm{ff}$.

54 Haslmayr, Antwort, Aiiiv: "So spüren und schlissen wir/ das ihr die jenigen nun von Gott erkoren seyt/ die die ewige Theophrastiam unnd Göttliche warheit erweitern solten/ wunderbarlicher weiß biß hieher reseruiert, villeicht auff die zeyten deß geprophetierten Eliae Artistae zu achten."

55 Ibid., Aiiiiv: "[...] bey welchen Thesauris auch die wahren freyen unerhörten kunsten Bücher ligen/ deren die Menschen Kinder noch nie gedacht haben." 
the books of the pagans to place the eternal wisdom abandoned in the middle and to love the darkness." ${ }^{56}$ The book of the pagans were the scholastic writings, which were still widely read at the universities, but which did "not lead to Christ." ${ }^{\prime 5}$ Again borrowing from the Fama, Haslmayr dismissed the teachings of Aristotle and Galen, and criticised

[the] asinine world-wise Christians of the universities, [who] believe that there can neither be found a better philosophy than Aristotle's, nor a more certain medicine than that of Galen or Avicenna, [who] have reinforced the teaching of false idols and have denounced the doctrine of eternal wisdom. ${ }^{58}$

Haslmayr rejected the "idolatrous pagan writings" of the scholastic masters of university, by which he referred to their idolizing of Aristotle and Galen. ${ }^{59}$ Not God or Christ, but pagan masters were heralded as Gods by academic scholars. In response, God and His "priests of the Rose Cross" should come so that the world will see that "all [the world's] wisdom so far has been nothing to God

$5^{6} \quad$ Ibid., Aiiiiv: "O wie verzweyfelt unnd unglückseelig ist die stund aber/ darinn uns das gluck wirdt verhindert/ darinn uns die ewige weißheit zwischen Stül unnd Benck nider zu setzen/ unnd die Finsternuß zu lieben gebetten wirdt/ durch der Heyden Bücher."

Ibid., Br: "[...] auff das die Christenheit sehe/ das man der vergebnen Welt weißheit der Heyden/ unnd ihren Meyster/ die nicht nach Christum gehet Col. 2. Ganz und gar durchauß nicht bedörfft hette." By the word "pagan," Haslmayr did not solely refer to pagan wisdom, but also, in a more traditional interpretation of pagans, to immoral acts of pagans such as "destruction of the empire, invasions of tribes, oppression of the poor, pomp and pageantry of the princes, hoarding of possessions," see ibid., Br. Cf. also: ibid., Aiiiiv .

$5^{8}$ Ibid., Biir: “[...] das ist von euch Thorechtigen Weltweysen Christen der hohen Schulen geredt/ die ihr vermeint es konne kein bessere Philosophia gefunden werden/ als Aristotelis also auch kein gwissere Medicin/ als Galeni oder Auicenae die Lehr der Abgötter habt ihr fulciert/ unnd die Lehr Sapientiae aeternae [...] habt ihr verketzert."

59 Ibid., Biir: "Und der Abgöttischen Heyden Schrifften/ von ihren vergeblichen Summo bono, unnd falschen Philosophia, falschen Medicina, falschen Sacrificien, dem Vulturno, zugericht/ noch dißen H. Sentenz: Et non erunt in memoria priora quoniam odibilia opera Domino faciebant, per medicamina \& sacrificia iniusta Electi mei non laborabunt frustra ibi. Esaiae 65." The latter part refers to Wisdom 12; see: Wisdom 12:3-4 (New American Bible): "For truly, the ancient inhabitants of your holy land, whom you hated for deeds most odious - works of sorcery and impious sacrifices." Cf Isaiah 65:22-23 (KJV, as usual): "They shall not build, and another inhabit; they shall not plant, and another eat: for as the days of a tree are the days of my people, and mine elect shall long enjoy the work of their hands. They shall not labour in vain, nor bring forth for trouble; for they are the seed of the blessed of the Lord, and their offspring with them." Volturno is a God of rivers, and it is also a river in Italy. 
but foolishness." ${ }^{60}$ The Rosicrucian brethren were understood to be priests and mediators between God and the world. They performed the sacred rites that were not to take place in any religious or academic institution, but which were necessary in the divine plan of the development of history. Again, not only the lion but also, and more importantly, God's ministers, the Rosicrucians, have a special task during the Final Days: they had a religious and philosophical role to play, as they would both defeat the enemy of Christ and debunk pagan knowledge.

Haslmayr acknowledged the Fama's rejection of academic scholars, but he did not advocate for a reform in academia and the arts. He described an educational programme that should have been implemented at the schools: "[W]e all should have educated our schools and students only from the Creator of the new Creature and from the Reviver Jesus Christ, Son of God, sent by the celestial Father into this world."61 His claims were written in the past perfect tense, drawing attention once more to the lack of time for a thorough transformation of education and knowledge. The world could not be reformed anymore, but one could learn divine secrets from the Rosicrucians and thereby follow the true path of Christ.

Although they had identified themselves as physicians and had promoted reform, Haslmayr believed that the brethren's contributions during the Last Days were neither medical nor reformative, but strictly apocalyptic: more so than the lion and Elias Artista, they were supposed to overcome contemporary folly by the disclosure of God's wonders:

So come, you small flock of Christ, linger no longer, it will soon be night, the bright day is drawing to its close, the seducers of the people of the darkness are there. So God with His wonders [is] with you and through you, as with His Moses, Joshua, Samson, Daniel, Job, David, and the apostles; who will be against you? ${ }^{62}$

6o Haslmayr, Antwort, Biiv: "drauff nun der Allmächtige Gott kompt (mit seinen Priestern von R.C.) auff das die Welt sehe/ das all ihr Weyßheit bißher nichts vor Gott sey gwest/ als ein Thorheit $[\ldots]$."

61 Ibid., Biir: "[...] das wir alle allein ex nouae Creaturae Creatore \& Regeneratore Iesu Christo Dei Filio, a Patre superno misso in hunc mundum; [...] unsere Schulen unnd Schuler sollen educiert haben."

62 Ibid., Aiiiiv: "So komme doch du kleines heuflein Christi. Saume dich nit länger/ es will gar Nacht werden/ der helle Tag hat sich geneyget/ die verführer deß Volck der Finsternussen seind duck [sic]. So Gott mit seinen Magnalien mit unnd durch euch/ wie mit seinen Mose/ Josua/ Samson/ Daniels/ Job/ David/ Apostolis/ wer will wider euch sein?" 
The world, in Haslmayr's view, was approaching the final hour of daylight, but apart from the small group of enlightened Rosicrucians it was yet shrouded in darkness. The brethren, in imitation of biblical and apocalyptic figures, were to bring light into this period of final darkness, which means that humanity's hope was directly linked to the brotherhood's appearance on the world stage. It was in this context that he wrote that "we judge from your joyful statements which leap into our hearts, that we may also justly rejoice in a happy time."63 The happy time is not the result of a reformation, and is presumably not a reference to the New Jerusalem of after the Last Judgement. Instead, it referred to the final revelations and outpourings of wisdom brought to the world by the Rosicrucians. The brethren, whose Fama had not yet been published, were to "come with the pacific word, with the simplicity and majesty of the celestial wise men" so that Christ would pass a favourable Judgement. ${ }^{64}$ Evidently, if Christ's Judgement depended on the good works performed by the people, their salvation did not depend on sola fide, the Lutheran doctrine according to which salvation could be granted through faith alone. Thus, when Haslmayr warned his readers that God could soon unleash his wrath, he admonished them to change their behaviour, to become good Christians in imitation of the Rosicrucians - presumably to secure admittance for themselves into the New Jerusalem.

As God's messengers and the revealers of wisdom during the Last Days, Haslmayr took the Rosicrucians for men walking in the footsteps of Christ. He implored the Rosicrucians to "hide no longer, o you warning brothers and undeceiving Jesuiters." 65 With the term "Jesuiters," he was not referring to the order founded by Ignatius of Loyala (1491-1556), but to the people wandering on the path ("iter") of Jesus. The Rosicrucians were the epitome of "Jesu-iters" thus defined. ${ }^{66}$ In this sense, the brethren were like the magi, "while the light

63 Ibid., Aiiv: "So befinden wir/ auß ewren/ in unsern Herzen springenden/ freudenreichen Editionen, das wir uns billich einer glückseligen zeit auch rühmen mogen." Compare the following passage from the Fama, 91-92: "Nachdem der allein wyse und gnädige Gott in den letzten Tagen sein Gnad und Güte so reichlich über das Menschliche Geschlecht außgossen, daß sich die Erkantnuß/ beydes seines Sohns und der Natur/ je mehr und mehr erweitert/ und wihr uns billich einer glücklichen zeit rühmen mögen [...]."

64 Haslmayr, Antwort, Bv: "In dem sich diß 1612 Jar/ der Richter undergang erhebt/ zum anfang der schmerzen/ so kompt mit den pacifico verbo/ Sophorum caelestium simplicitate \& maiestate $[\ldots]$."

65 Ibid., Aiiir: "So verbergt euch nicht lenger/O ihr wahrnenden Brüder/ und unbetrieglichen Jesuiter."

66 This relates to the Rosicrucian phrase: "Jesu mihi omnia," "Jesus is everything to me." See also the preface to the Confessio in the German edition of the Confessio (Gdańsk, 1615), in 
of God has also appeared to you, just as the star led the magi to come to God, to teach the erring world the true way of the eternal philosophy, such as the knowledge of the Messiah, and the light of nature." ${ }^{\prime 67}$ The Rosicrucians were God's messengers, because He had chosen them to speak His Word, in imitation of Christ. The eternal knowledge they were to reveal was both divine and natural: knowledge of the Messiah Christ, and knowledge of God's creation, for which Haslmayr employed the term "light of nature," a term used variably by philosophers throughout history, but particularly also by Paracelsians. ${ }^{68}$ In parallel with this twofold knowledge, the method for its acquisition was also twofold: new things were to come to light not only by divine illumination, but also as a result of human investigations and discoveries in the natural world.

\section{Paracelsus and the Study of the Natural Realm}

Haslmayr, who now drew explicitly on the Fama and implicitly on the general reformation that it propagated, placed further emphasis on the study of the natural world. He wrote that

at the time of the empire of the Holy Spirit or of the freedom of the Gospel, of which you report, in which are indicated and found not only half of the unknown and hidden world, but many wondrous and previously unknown works and creatures of nature, of herbs, animals and noble stones or metals. ${ }^{69}$

Haslmayr's reference to the reign of the Holy Spirit seems reminiscent of the age of the Holy Spirit described by Joachim of Fiore and mentioned by Julius Sperber and Tobias Hess, but Haslmayr did not expect a third earthly age but hoped that in the remaining time, however brief, humans might be enlightened

which the anonymous author refers to Haslmayr's Antwort and explains that true Jesuits walk in Christ. On this preface, see below, section 4.2.

67 Haslmayr, Antwort, Aiiir: "Weil euch das Liecht Gottes/ wie den Magis der stern vorgeleucht zu Gott zukommen/ auch vorleuchtend erschinen ist/ die verwierte Welt zu Lehren den wahren weg der ewigen Philosophei/ als der Erkantnuß Messiae, und der Natur Liecht [...]."

68 On the light of nature, see above, pp. 143-144.

69 Haslmayr, Antwort, Aiiir: “[...] bey der zeit deß Imperii Spiritus Sancti, oder Libertatis Evangelii; von der ihr meldet/ darinn nicht allein der halbe theil der unbekanten unnd verborgnen Welt/ sonder viel wunderliche/ unnd zuuor nie gesehne werck unnd gschöpff der Natur/ von Kreutten Thier/ unnd edlen Steinen oder Metallen angezeigt unnd gefunden werden." Cf. Fama, 91-92: “[...] daher dann nicht allein das halbe theil der unbekandten und verborgenen Welt erfunden, viel wunderliche und zuvor nie geschehne Werk und Geschopff der Natur uns zuführen [...]." 
through the brethren's studies of the world. With such hopes, Haslmayr's views share some similarities with those of John of Rupescissa, Arnald of Villanova, and Roger Bacon, who also expected progress of science for the benefit of the fight against the Christian enemy, that is, for apocalyptic reasons. ${ }^{70}$ Likewise for Haslmayr, knowledge of natural secrets would prepare for the Last Judgement. The discoveries related to the mineral, vegetable, and animal worlds, presumably found in the Americas, were, in his view, part of a final outpouring of knowledge.

This increase of knowledge owing to the brethren's study of creation was in accordance with the divine plan, because - so Haslmayr argued while paraphrasing the Fama - God desired that we "shall shine light and splendour in His Son, so that the knowledge of both His Son and of nature will expand itself more and more, as you [Rosicrucians] wish and declare."71 The brief period of illumination was accompanied by a sense of epistemic progress, in which there was a specific role for human agency. While human beings were unprepared to fight the Antichrist or disclose divine secrets-those tasks being left to divine intervention and God's priests, the Rosicrucians - they could still all engage in the study of the natural world and help bring to light what had remained hidden. Haslmayr's optimism in this regard was closer to the Rosicrucian Fama than his otherwise bleak view of history: what was to be revealed and man's role within it were very similar to what was foretold in the Fama, but on the questions of when and why such revelations were to take place Haslmayr nurtured less optimistic expectations.

The natural secrets, Haslmayr continued, had been investigated by the Rosicrucians' Rotae (wheels). The Rotae were mentioned in the Fama several times, but their meaning is obscure. At one point, they seem to represent wheels of time's keeping, encompassing everything from God's "Fiat" until his "Pereat"; ${ }^{72}$ elsewhere the "Rotae of the world" refer to the most artistic book kept in the

70 On this, see above, section 1.3.

71 Haslmayr, Antwort, Aiiv: "Weil dann der Allmechtige getrewe Gott [...] will das wir [...] in seines Sohns/ liecht und glanz sollen scheinen/ also das sich die erkandtnuß/ beydes/ seines Sohns und der Natur/ je mehr und mehr/ als ihr begert und meldet/ erweiteren möge." Cf. Fama, 91-92.

72 Fama, 105: "Ob wihr wohl freywillig bekennen/daß sich die Welt innerhalb hundert Jahren treflich gebessert/ seynd wihr doch vergewissigt/ daß unsere axiomata unbeweglichen werden bleiben, biß an den Jüngsten Tag/ und nichts wird die Welt auch in ihrem höchsten und letzten Alter zusehen bekommen/ dann unsere Rotae nehmen ihren anfang von dem Tag/ da Gott sprach: Fiat, und enden sich wann er sprechen wird Pereat." Cf. ibid., 11o, 121. 
Rosicrucian library $7^{73}$ and after describing their rediscovery of Rosencreutz's vault, the brethren explain that the Rotae instructed them to disclose several of their books, including the "M. Hoch.," which possibly refers to the Chemical Wedding. ${ }^{74}$ For Haslmayr, the wheels seem to refer to a certain key which opens the door to knowledge of every aspect of the world. They may have been derived from the medieval author Ramon Lull (ca. 1232-ca. 1315), under whose name writings were published that promoted alchemical medicine. ${ }^{75}$ Lull placed nine letters on concentric circles, so-called wheels, which could be rotated so as to form new combinations, and which reflected and explained the universe. These letters represented the nine dignities of God. As the wheels represented the universe, God was believed to be able to ascend and descend through all levels and thus through the universe. ${ }^{76}$ Similarly, Haslmayr argued that the Rosicrucian Rotae could be used to study and understand the world:

So now we do not doubt at all that your Rotae of the world will now have espied and investigated such treasures well, among your other holy natural sciences and arts, to be brought to the light of day now by this time, alongside your rich, Christian, free, and formidable gifts. ${ }^{77}$

The brethren could use their Rotae to investigate the treasures and to comprehend the secrets of the universe. Here again their task was apocalyptic, namely to prepare for the end. Although not drawing on Genesis and thus on Mosaic physics strictu sensu, ${ }^{78}$ Haslmayr adapted the manifestos to a framework akin to an apocalyptic, pious philosophy.

Interestingly, the reason for studying the natural world was also missionary. Because the Word could be heard only by believers, it was to be complemented by a study of the world, so that "also the pagans may kindle the light from us, believers in Christ, so that one may recognise what is faithful and what is

\footnotetext{
73 Ibid., 110.

74 Fama, 121.

75 On this, see Chapter 2, n. 116.

76 Yates, The Occult Philosophy, 13-14. On Lull's art, see: Bonner, The Art and Logic of Ramon Lull.

77 Haslmayr, Antwort, Br: "So zweyflen wir nun mit nichten/ ewre Rotae mundi werden under andern ewren H. Natürlichen scientzen und Künsten/ solche Thesauros nun wol ersehen und erforscht haben/ neben ewren Reichen Christlichen freyen gwaltigen/ Donis nun bey der zeyt ans Tagliecht zugeben."

78 On Mosaic physics, see: Blair, "Mosaic Physics."
} 
unfaithful, what Christian or pagan."79 For the conversion of Jews and pagans, "highly illuminated minds," previously mentioned in the Fama, should stand up, "after the Ascension of Christ, to show the Jews and pagans the eternal light through the teaching of Christ and the work of wisdom, like Paul and the Cabalists or Aniads ${ }^{80}$ [educated] the lights of the pagans and the confused Christians." ${ }^{81}$ The only possible reform was that of the Jews and pagans, but this does not suggest any worldly reformation: it was a common belief among Protestants and Catholics alike that during the Last Days Jews could be converted to the Christian faith. ${ }^{82}$ For this reason, Haslmayr begged the Rosicrucians one final time: "Come, $\mathrm{O}$ you sober and pure priests anointed by the eternal wisdom, and flourishing with wonders, come, come, come in the name of the triune divinity, Amen." 83

One of the illuminated minds announced in the Fama, Haslmayr recalled, had been "Theophrastus Paracelsus, the magician," who will break through the darkness and dense fog which conceal the light. ${ }^{84}$ Paracelsus' principal relevance for Haslmayr was neither of a medical nature nor did he refer to the famous physician particularly for his natural philosophy, as the authors of the Fama had done. Instead, Paracelsus was seen as a harbinger of divine wisdom, so that also the relevance of Paracelsus was shaped according to an apocalyptic context. The Rosicrucians were seen as walking in the footsteps not only of Christian Rosencreutz, but also of Paracelsus:

Like the German Theophrastus and your venerable father Christian von RosenCreutz, [who is] also of noble German blood, now you from the school of God and the eternal philosophy [are] offering to teach us, and [you are] also coming in public to delight us with a sound mind. ${ }^{85}$

79 Haslmayr, Antwort, Aiiv: “[...] und auch die Heyden das Liecht anzünden mögen von uns Christgläubigen/ damit man erkenne/ was gläubig oder ungläubig sey/ was Christ oder Heyd sey?"

8o Aniads might refer to Virgil's Aeneid, which tells the story of Aeneas, or alternatively to Aniadum, which in Paracelsian terminology refers to a celestial body that is received from the Holy Spirit. For the latter interpretation, see: Tilton, "Rosicrucian Manifestos," 135.

81 Haslmayr, Antwort, Aiiir: "[...] darzu dann hocherleuchte Ingenia auffstehn müssen/ nach der Himmelfahrt Christi/ den Juden und Heyden das ewige Liecht zu zeigen durch Christi Lehr und Weißheits Arbeit/ als Paulus und die Cabalisten oder Aniadi, unnd Liechter der Heyden/ und der verwierten Christen."

82 Hotson, Johann Heinrich Alsted, 218-222.

83 Haslmayr, Antwort, Bv: "Darumb so kompt ihr/ O ihr nüchtern und reinen Priester von der ewigen weißheit gesalbet/ unnd mit miraculen Florierend, kompt/ kompt/ kompt/ im Namen der drey eynigen Gottheit/ Amen."

84 Ibid., Aiiiv:: "Theophrastus Paracelsus magus." Cf. Fama, 91-92.

85 Haslmayr, Antwort, Aiiv: "So befinden wir [...] das wir uns billich einer glückseligen zeit 
Haslmayr's aim was to reveal the eternal and Paracelsian wisdom that was now brought to light by the Rosicrucians in "this final world." ${ }^{86}$ In his Answer, the link to Paracelsus was even more explicit than it had been in the Fama. As a self-professed Paracelsian physician, Haslmayr was obviously inspired by the works of this sixteenth-century medical reformer. Already in his opening sentence, he identified his thought with that of the "rejected Theophrastian school," acknowledging the historical situation in which Paracelsus and his followers were ridiculed and dismissed by traditional Galenic physicians. ${ }^{87}$

The identification of divine wisdom with Paracelsianism had become increasingly popular in the years prior to 1610, when Paracelsus' genuine and spurious works were published in several German and Latin editions. Like other Paracelsians before him, ${ }^{88}$ Haslmayr contended that "the doctrine of Theophrastus, which is just and without blemish, must flourish in eternity with the wise men of God (Sap. 4 and 6). And no human being in the entire ridiculing world, nor the devils of the Gates of Hell will be able to overpower it." 89

The relevance of this doctrine was apocalyptic, but its contents were related to divine prophecy, alchemy, and medicine. In this, Haslmayr had recourse to several Paracelsian and pseudo-Paracelsian works. Although Huser, in his editions of Paracelsus' works at the end of the sixteenth century, had at times suggested that some works were spurious, at this time there was no clear dis-

auch rühmen mögen/ an Theophrasto Germano und ewren Ven. Patrem Christ. Von RosenCreutz/ auch Teutschen edlen Geblüts/ nun euch auß der Schul Gottes und ewigen Philosophei uns zu lehren/anerbietende/ auch geoffenbart kommende/ uns sana mente zu erfrewen."

86 Ibid., Bv: "Lasset uns der H. Gütter der Herrligkeit deß allerhöchsten Gottes/ und seiner Euangelischen Libertet, durch Theophrastum, und euch diser letzten Welt fürgeschriben/ nicht weiters beraubet/ noch so ganz verborgen sein."

87 Ibid., Aiir: "Wir geringfügige von der Theophrastischen verworffnen schul/ und Tyrolischen Mineral Gebürg/ wüntschen/ von dem allein weisen/ allein Gnedigen/ barmherzigen Gott Schöpffer aller Magnalien/ neben unserem armen Gebett/ Christbrüderlichen gruß und liebe/ alle zeit von grundt unsers Herzens zuvor. Unser einfeltige antwort/ euch sonders erleuchten Apostolischen Männern Gottes/auff ewr so mildreiche anerbittung an die Heupter/Stande/ Gelehrten/ unnd auch gemeinden und ungelehrten Europae, seind wir als bald entschlossen gwest zu geben/ als uns nemblich Anno 1610. Erstlich hierinn in diß Landt Tyrol/ ewer schreiben Fama Fraternitatis R.c. schrifftlich zukommen/ weilen wirs getruckt/ noch nie beßhero ansichtig mögen werden/Drauß wir die grosse Trew/ Lieb unnd milte Barmherzigkeit Gottes/ auch zu disen lesten zeiten/ so reichlich sich durch ewre Theophrastiam und gottes geschenck/ herfürgebene/ vernemen [...]."

88 Cf. above, Chapter 2.

89 Haslmayr, Antwort, Biiv: "[...] das Theophrasti Doctrin, gerecht und ohne macel, floriern muß/ in ewigkeit mit den wysen Gottes. Sap. 4.6. und kein Mensch der ganzen Spöttischen Welt/ noch auch die Teuffel der Höllischen Pforten/ werdens mögen ubergwältigen." 
tinction between Paracelsus and pseudo-Paracelsus. Haslmayr expected the brethren to help in the Final Days on earth by making Paracelsian philosophy public. He asked the Rosicrucians to

come with the theological necrocomia, the nectromancy of the blessed, come with the philosophical sacred magic of Bethlehem and the astronomy of grace, with an angel of the good council [Christ] and with the sacred evestrum of the sign star, come with the primordial medicine, and archidoxical ${ }^{90}$ mysteries and prescribed Cabalistic Christian liberal arts, and with wonders of the eternal uncontaminated Wisdom of Sophia and of the undefiled Theophrastian pure way of God. ${ }^{91}$

"Theological necrocomia" refers to divine prophetic signs in the firmament. The term originated in Paracelsus' Book on Images and his Great Astronomy (or Philosophia sagax), which was read by Haslmayr as early as $1588 .{ }^{92}$ It was discussed in pseudo-Paracelsian writings such as the Liber Azoth, and the term was explained by Gerard Dorn as follows: "Necrocomia are wonderful forebodings, announcements of some future thing by signs fallen from the air above the earth, such as crosses in earlier times and many other things." ${ }^{93}$ For Haslmayr, these forebodings have religious and historical significance.

The closely related term nectromantia should not be confused with necromancy, as it refers not to communication with the dead but to the art of revealing secrets. That term also originated in Paracelsus' Great Astronomy, where it is defined as the study of the disclosure of secrets which are kept

$90 \quad$ The printed version reads "arahidoxischen," but the term should be "archidoxischen," possibly referring to the pseudo-Paracelsian Archidoxis magica: I, 14; 437-498, which concerns magical signs.

91 Haslmayr, Antwort, $\mathrm{B}^{\mathrm{v}}$-Bir: “[...] kompt mit der Theologischen Necrovvenia und Beatorum Nectromantia, kompt mit der Philosophischen Bethlemitica sancta Magia und Astronomia gratiae, Angelo boni Consilij, unnd Euestro sancto Stellae signatae, kompt mit den Necrolischen Medicament/ unnd Arahidoxischen misterijs, und verordenten Cabalistischen Christfreyen Künsten/ und Magnalien Sophiae aeternae incontaminatae, \& intactae Theophrastiae purae Dei Viae." "Necrovvenia" should be "Necrocomia." On the meaning of "necrolisch," see: pseudo-Paracelsus, Liber Azoth, I, 14; $55^{2}$.

92 Paracelsus, Liber de Imaginibus, I, 13; 359-386. On Haslmayr having read the Great Astronomy, see above, p. 220.

93 Paracelsus, Astronomia Magna, I, 12; 275-406; Pseudo-Paracelsus, Liber Azoth, I, 14; 547595, esp. 549 f.; Dorn, Dictionarum theophrasti paracelsi, 70: "Necrocomia, sunt prodigiosa praesagia, rei cuiuspiam futurae praenuntia per signa ex aëre super terram decidentia, ut cruces olim ac alia multa." 


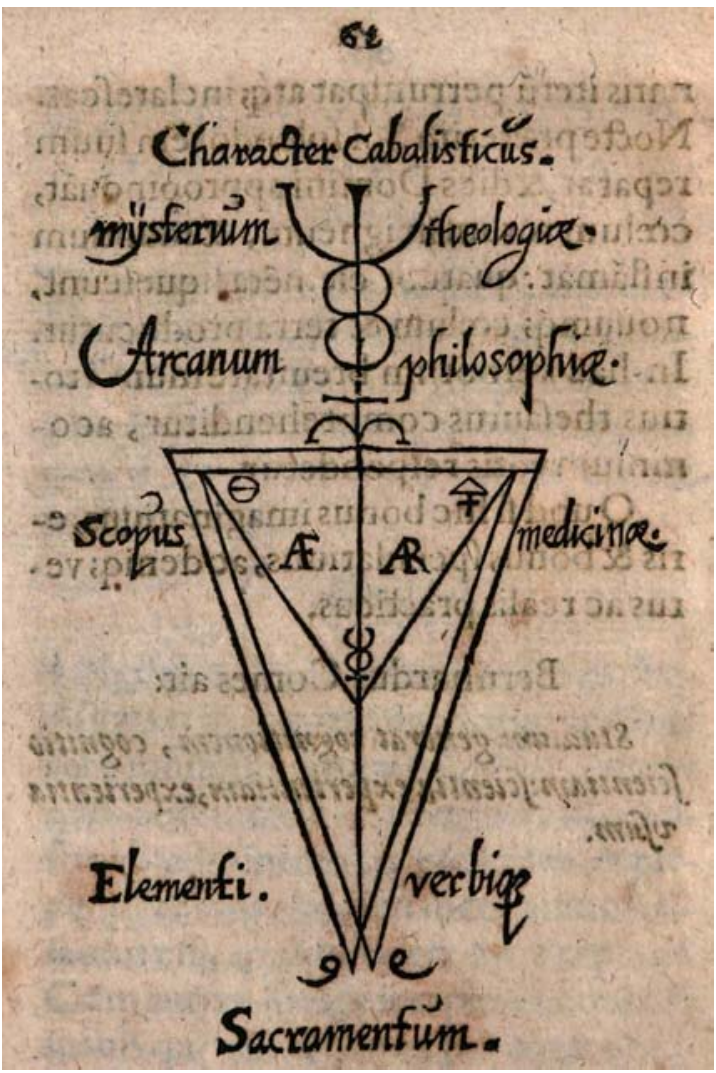

FIGURE 9 Benedictus Liberius, Nucleus sophicus (1623), Paracelsus' Signatstern, Bayerische Staatsbibliothek

hidden inside human beings. ${ }^{94}$ The "sacred evestrum," a term that is possibly taken from pseudo-Paracelsian texts, referred to a spiritual and astral body that could be found in both the universe and in man. ${ }^{95}$ Here it is related to Paracelsus' sign star, but it implicitly also recalls the star that appeared over

94 Paracelsus, Astronomia Magna: I, 12; 14-444, see especially 87-88: "also verstehet auch die nectromantiam, das die heimlikeit der menschen und dasjenig so sie verbergen, auch seind die solchs wissen. Nicht alein das einer vermein, darumb das niemant bei im ist, dasselbig alein wisse, sonder es ist noch etwas, das wir menschen nicht sehen, das bei uns ist in allem unserm verborgnen, worten und werken. Der mit demselbigen reden kan und weiß mit im zu handlen, der erforschet alles das, so der mensch gar verschlossen zu sein vermeint." See also: Möseneder, Paracelsus und die Bilder, 167, 173.

Pseudo-Paracelsus, Philosophia ad Athenienses, I, 13; 387-423, esp. $413 \mathrm{ff}$. 
Bethlehem at Christ's birth. ${ }^{96}$ It was complemented by "archidoxical mysteries," which presumably have their origin in the Archidoxis and refer to remedies. ${ }^{97}$

These mysterious terms hint at Haslmayr's understanding of the divine and alchemical nature of Paracelsus' doctrine. ${ }^{98} \mathrm{He}$ wished to suggest that the Rosicrucians were involved in interpreting divine signs, forecasting the future, and in an alchemical and medical study of the hidden reality of man and the universe. None of these Paracelsian terms had been mentioned in the Fama, but Haslmayr interpreted the manifesto's message in these terms, so as to combine and identify Paracelsianism with Rosicrucianism, and to draw the Rosicrucian Fama into a specific set of beliefs and expectations.

Haslmayr further suggested that the Rosicrucians combine Paracelsian sciences and Christian teaching with the study of the Cabala. The true liberal arts mentioned above he now identified to be cabalistic in nature. Cabala, according to the Fama, had been studied by Christian Rosencreutz, but this art was also promoted in Paracelsus' Great Astronomy, in pseudo-Paracelsian writings, and by Paracelsians such as Bodenstein and Toxites. ${ }^{99}$ In his Great Astronomy, Paracelsus understood Cabala as a magical art, as it appears under his discussion of magic. ${ }^{100}$ For Paracelsus, Cabala was some sort of natural magic, which was related to the study of the harmonies between the microcosm and macrocosm, the spiritual powers that dwell in nature, and the astral powers that influence the earth. Just as Paracelsus had turned away from the medieval, Jewish Kabbalah and the study of the Sefirot, so Haslmayr understood Cabala in a magical and Christian manner.

It thus becomes apparent that Haslmayr's Answer differs in substantial ways from the Fama to which it responded. Firstly, the role of Paracelsus is much bigger than in the Fama, and the Paracelsian elements discussed were not naturalphilosophical but religious and alchemical. While in the Fama, the brethren drew on Paracelsian views, Haslmayr did not hesitate to fully identify the two movements with one another, Rosicrucianism and Paracelsianism, by which he made the brethren's message thoroughly apocalyptic and religious. Also the figures of the lion and Elias Artista had their origin in Paracelsian literature. Haslmayr was eager to spread Theophrastian thought, and he co-opted the Rosicrucian Fama to get this message across.

\footnotetext{
96 On Haslmayr's and Paracelsus' Signatstern or sign star ("stella signata"), see: Gilly, "Theophrastia Sancta," 174.

97 Cf. Paracelsus, Archidoxis (ed. Huser), vol. 6.

98 Paracelsus, Astronomia Magna, I, 12; 14-444.

99 Bodenstein, $C P$, vol. 1, nr. 6, 116, 123; Toxites, $C P$, vol. 2, nr. 58, 374 .

100 Paracelsus, Astronomia Magna, I, 12; esp. 78, 83-85.
} 
Haslmayr went so far as to suggest that the Rosicrucians were Paracelsians bringing to light Paracelsian wisdom. He was one of the early modern authors who is seen to have transformed Paracelsianism into a religion, the so-called "Theophrastia Sancta" - a name that hints at the religious influences of Paracelsus. ${ }^{101}$ At the end of the Cabalistic Theology (1618), which was published under the name of Paracelsus but written by Haslmayr, the author described himself as a "disciple of the Theophrastia Sancta." ${ }^{102} \mathrm{He}$ also mentioned the "Theophrastia Sancta" in his earlier Revelatory Oration (1612), a text sent to Maximilian III. In that text, he claimed that science should be based on theology, and that "Naristotle" ("fool Aristotle"), Galen, and Cicero had not promoted such a science. By contrast, the "Theophrastia Sancta," much like theosophy, was instead grounded in Christianity. ${ }^{103}$ The term "Theophrastia Sancta" signified to Haslmayr a specific type of theosophy, and he clearly read Paracelsian works as well as the Rosicrucian manifestos through a religious, notably apocalyptic, lens.

A second difference between the Fama and Haslmayr's Answer is that the philosophy of the brethren as discussed by Haslmayr was much more clearly associated with Christian thought than had been the case in the first manifesto. This is evident from his frequent use of Scripture, his references to biblical events, his traditional understanding of history, and from the fact that he emphasised the Christian character of Paracelsus and the Fama more than they themselves had done. Haslmayr's response to the Fama was first and foremost that of a religious person.

Thirdly, and most strikingly, Haslmayr's view was undeniably eschatological, and radically differed from the Fama's optimistic message, which means that it was not chiliastic in nature. ${ }^{104}$ Remaining close to traditional apocalyptic, the task Haslmayr took upon himself was to warn and to prepare his readers. Although he made use of apocalyptic tropes mentioned in the Fama and later also in the Confessio, according to Haslmayr: 1) there was no new time expected on earth; 2) the Antichrist was not the Roman pope; 3) the defeat of the Antichrist was to occur by divine intervention (and God's priests) and not by humans, not even by the lion; 4) the only role for humans was the study of the natural world; and 5) there was a limited sense of earthly progressresults from earlier investigations were to be revealed and the world could be

\footnotetext{
101 Cf. Gilly, "Theophrastia Sancta," 173; Murase, "Paracelsismus und Chiliasmus," 223; Tilton, "The Rosicrucian Manifestos," 129-130.

102 Haslmayr, Theologia cabalistica, 49.

103 Gilly, "Theophrastia Sancta," 172-173.

104 This conclusion is contrary to: Gilly, Adam Haslmayr, 85 .
} 
studied, but this only had relevance for the Last Days. Haslmayr amended these elements in such a way that they were no longer related to a call for reform: whereas the authors of the Fama had asked their readers to contribute to the reformation, for Haslmayr, there was room neither for a thorough religious or political reformation, nor for scientific or educational progress.

\subsection{The Instauration of Original Wisdom}

Haslmayr's Answer left few traces in the ensuing reactions to the Rosicrucian manifestos. Some elements continued to play a role, but the responses that will be discussed here deviated considerably from Haslmayr's pessimistic outlook and fear concerning the final tribulations; and the apocalyptic figures central to the manifestos played a far less prominent role.

Exemplary are the anonymous letters attached to the German version of the Confessio published in Gdańsk (1615), to which an anonymous preface and another edition of Haslmayr's Answer was appended. These texts were particularly vague but optimistic about imminent events, interpreting the manifestos as messengers of long-lost wisdom, and inserting them into the tradition of a perennial philosophy. Their authors have remained unknown. By the time of the 1615 publication, Haslmayr, whose name was publicly associated with the Rosicrucians, had already for three years been chained in the galleys. Others, having learned of Haslmayr's sentence from the title page of the Fama, might have taken the fate of that Paracelsian theosopher as a warning, for many further replies were written anonymously. At the same time, these replies were styled after the very example of the Fama itself, which had also been published anonymously, with all Rosicrucian brethren mentioned in it, including their "father" Christian Rosencreutz, named only by their initials. Unlike many other writings from the enormous flood of anonymous pamphlets, the 1615 letters reached a wide audience because of their prominent placement attached to the Fama and Confessio. ${ }^{105}$

Prefixed to the German edition of the Confessio was an undated Preface to the reader. Its author explicitly addressed the changing times and, like Haslmayr, announced the end of a period of disasters. He did not expect the final tribulations, but conveyed a message of optimism and excitement:

105 This edition of the Confessio, with the same preface and replies, was later translated into Dutch and reprinted in Frankfurt in 1615 by Jan Berner. 
The beatific aurora wishes now to dawn, which, after the ending of the dark Saturnine night, entirely faded out with its splendour the moonlight or the small sparks of heavenly wisdom that are still existing among the people, and which is a precursor of the lovely sun, which with its pure and fiery shining rays will bring forth the blessed day, for which many pious hearts nurture a fervent longing. ${ }^{106}$

Saturn signifies night, darkness, and melancholy (saturnine), but, as in the tradition of the philosophia perennis, the author explains that small sparks of wisdom have remained that will now once again turn into a blazing fire and culminate in the "lovely sun." The reference to the new period remains vague, but it seems to imply that another earthly age was on the horizon. The ending of the saturnine night may also be explained by alchemical analogy. Saturn was associated with lead, carrying the same symbol as that metal. In alchemy, lead represented the lowest stage of the alchemical process; it was to be perfected in order to transform it into gold, a metal that was symbolised by the sun. In this reading, through a process of transmutation lead will be purified through several stages, including the moon (the "moonlight," silver), until finally the "lovely sun" (gold) will bring the "blessed day."

The Preface was particularly apocalyptic, as it was entirely devoted to the revelation of secrets, but this revelation was, indeed, specified to contain alchemical and medical knowledge. Upon the new period, its author claimed, all metals will be transformed into gold, the purest of all metals. Hidden treasures returning to light will function as a means for the transmutation of metals and as a medicine for human bodies and fears:

These [heavenly treasures of divine wisdom] will be the true royal ruby, and a noble radiating carbuncle, about which one has learned that it emits a fiery sheen and light in the darkness, that it is a perfect medicine to all bodies and imperfect metals, capable of transforming these into the best gold, and of taking away from human beings all disease, fear, distress, and dreariness. ${ }^{107}$

106 Confessio (Gdańsk), Preface, Av ${ }^{\mathrm{r}}-\mathrm{Av}^{\mathrm{v}}$ : "Es wil nunmehr anbrechen die selige Morgenröhte/ welche nach Ablauffung der finstern Saturnischen Nacht/ deß Mondesschein/ oder die geringe Füncklein der himmlischen Weißheit/ so noch bey den Menschen verhanden/ mit ihrem Glanz gar vertrübet unnd ein Vorbotte ist der lieblichen Sonnen/ die mit ihren reinen unnd fewrigglentzenden Stralen/ den seligen Tag/ nach welchem viel fromme Herzen ein sehnliges Verlangen haben/ herfür bringen wirdt."

107 Ibid., Avir: "Dieses [alle Himlische Schätze der Göttlichen Weißheit] wird sein der rechte Königliche Rubin/ und edle leuchtende Carfunckel/ von welchem man etwa gelehret/ daß er ein fewrigen Glanz und Licht im Finsternüß gebe/ ein vollkommene Medicin sey 
These treasures seem to have qualities similar to the philosophers' stone (lapis philosophorum), with which alchemists believed that all metals could be transmuted into gold and which could work as a panacea, a universal medicine. They could purify body and world in analogy with an alchemical process upon the new age. Prophecy, alchemy, and medicine were related not in the sense of apocalyptic alchemy (alchemy used for revelations), ${ }^{108}$ but rather as what might be termed "alchemical apocalyptic," that is: the revelation of alchemical secrets as reserved specifically for the last days of the era.

This beatific dawn was to bring with it further apocalyptic revelations, because "in the light of this day, all heavenly treasures of divine wisdom and all hidden invisible things in the mystery of the world will verily be known and espied after the first fathers and after the teaching of the old wise men." 109 All wisdom once known to Adam and the Patriarchs was to return to the world, which concerned the secret nature of nature itself, used by Adam to name all animals and birds. ${ }^{110}$ The Fall had blurred much of this primordial understanding, the author continued, but "some of God's friends," including Solomon, who is mentioned also in the Fama, had yet been enlightened by this divine spark. According to his own testimony, Solomon had known all aspects of creation, including the vegetable, animal, and human realms. Upon insistent prayer he had received from God insight into all hidden secrets and the origin of the world and of time, as the author of the Preface testifies:

He knows how the world was created, understands the power of the elements, the beginning, middle and end of time, how the day becomes longer and shorter, how the time of the year changes itself, how the year's cycle works and the stars are positioned, so that he understands the nature of the tame and wild animals, how the wind blows, and what people have in mind, he knows all species of plants, the powers of roots, and other things. ${ }^{111}$

auff alle Corpora/ unvollkommende Metallen/ dieselben in das beste Golt zuverwandeln/ unnd alle Kranckheit/ Angst/ Noth und Trübselighkeit von den Menschen hinweg zunehmen."

108 Cf. above, p. $121 \mathrm{ff}$.

109 Confessio (Gdańsk), Preface, Avv: "[...] bey welchem Tages Schein denn alle Himlische Schätze der Göttlichen Weißheit/ auch aller verborgenen unsichtbaren Dinge in der Welt geheimnüß/ nach der ersten Vätter unnd Alten Weisen Lehre warhafftig werden können erkant und gesehen worden."

110 Ibid., Aiiv: "Diesen Schatz hat vollkomlich gehabt unser erster Vatter Adam vor dem Fall/ welches daher erscheinet/ daß nach dem GOtt der HErr alle Thiere auff dem Felde und alles Gevögel unter dem himmel für ihn gebracht/ er einem jeglichen seinen eigentlichen Namen/ der ihm seiner Natur wegen gebüret/ hat geben können."

111 Ibid., Aiiv-Aiiiv: "Ob nun wol durch den trawrichen Fall in die Sünde/ diß herrliche Kleinot 
The notions of Adamic wisdom and of Solomon as proto-scientist, not much later to be described also by Francis Bacon in his New Atlantis, come together here. The author of the Preface took the Rosicrucian brethren to have access to the very same type of wisdom as Solomon, and they therefore knew the true essences and powers of all creatures-which was also the brethren's selfconception according to the manifestos. He thereby squarely placed the manifestos in the tradition of the philosophia perennis and connected this notion with hopes for a return to original conditions.

These views are reminiscent of what can be read in one of the other anonymous texts appended to the Confessio and published under the initials C.H.C., an interesting variant of C.R.C., the initials of Christian RosenCreutz. This text seems to have been appended to the other replies at a later stage, because the folio numbers do not correspond with the others. ${ }^{112}$ C.H.C. also believed that the Rosicrucians' outpouring of wisdom was an indication of an imminent age of original wisdom having returned, but rather than link it to alchemical secrets he understood the lost wisdom as Paracelsian natural philosophy. He explained that according to the Bible and Paracelsus, human beings had originally been created in the image of God, therefore possessing all "wisdom and knowledge of God and of all visible and invisible things." Man had lost this wisdom with the Fall, because "through the violation of the command he was fallen from the Spirit and the image of God into the external, corporeal, that is to say, the sinful flesh."113 Fortunately, this "complete beatific wisdom" could be sought and

der Weißheit verschertzet worden/ und eitel Finsternuß und Unuerstandt in die Welt kommen ist/ so hat doch Gott der HErr die selbe je biß weilen etlichen seinen Freunden bißher auffgehen und erscheinen lassen/ denn also bezeuget der Weise König Salomon von ihm selbst/ das er auff sein fleissig Bitt unnd Begeren ein solche Weißheit von Gott erlanget und bekommen habe/ daß er wisse wie die Welt geschaffen/ verstehe die krafft der Elementen/ der Zeit Anfang/ Mittel unnd Ende/ wie der Tag zu und abnehme/ wie die Zeit deß Jahres sich endere/ wie das Jahr herumb lauffe/ und die Sterne stehen/ verstehe auch die Art der zahmen und wilden Thiere/ wie der Wind so stürme/ unnd was die Leute im Sinne haben/ kenne alle Art der Pflantzen/ krafft der Wurtzeln und anders." Solomon's testimony is found in: Wisdom 7:17-22 (New American Bible): "For he gave me sound knowledge of what exists, that I might know the structure of the universe and the force of its elements, the beginning and the end and the midpoint of times, the changes in the sun's course and the variations in the seasons, cycles of years, positions of stars, natures of living things, temper of beasts, powers of the winds and thoughts of human beings, uses of plants and virtues of roots-What ever is hidden or plain I learned, for wisdom, the artisan of all, taught me."

112 C.H.C., Sendschreiben oder Einfältige Antwort (12 January, 1615).

113 Ibid., Avir: "Ich hab zwar durch Gottes gnad auß heiliger Biblischer Schrifft und deß hocherleuchten thewren Mannes theophr. Paracels. und anderer Gottes gelehrten Bücher erfandt unnd erlernet/ daß der Mensch anfenglich im Paradiß zu Gottes Ebenbild erschaf- 
found again in Christ by the Rosicrucian brethren, ${ }^{114}$ since "all great secrets and uncreated treasures" were confided by God to the Rosicrucians and could "still in this time be revealed and communicated." ${ }^{\prime 15}$ The Rosicrucians were again posed as inheritors of original knowledge, having access to all aspects of creation and having restored within themselves the image of God.

C.H.C. connected this perennial philosophy with the Paracelsian analogy between microcosm and macrocosm. Referring to Hermes Trismegistus, he agreed that above and below mirrored each other. According to C.H.C., what was in actu in the one cosmos, was in potentia to be found also in the other, thereby drawing on Aristotle's distinction between actuality and potentiality. ${ }^{116}$ The similarity is thus related to powers and abilities, and humans have all stars within them (as Paracelsus had explained) not physically but potentially, that is, as powers. C.H.C. described human beings as microcosms carrying heaven and earth in their fists. With this metaphor, he reversed an image evoked by the theosopher and Lutheran Saxon pastor Valentin Weigel (1533-1588). ${ }^{117}$ Weigel, in his Gnothi seauton ("Know Thyself," 1571) had explained how God had created man out of the macrocosm, which he can contain in his mighty fist. ${ }^{118}$

fen worden/ und in solcher Bildnüß/ die Weißheit unnd Erkandtnuß Gottes und aller sichtbaren und unsichtbaren dingen vollkommenlich gehabt und besessen. Auch daß er durch den Fall unnd Ungehorsamb/ solche Weißheit mehrertheils wieder verloren/ und dieselbige also bald sey in ihme verdunckelt/ hinein gekehrt/ und gleichsam gar außgeleschet worden/ dieweil er durch die Ubertrettung deß Gebotts auß dem Geist unnd Bildnuß gottes in das eusserliche leibliche/ nemblichen/ in das Sündliche Fleisch gefallen war."

114 Ibid., Aviir: “[...] die vollkommene selige Weißheit/ so in Adam verloren worden/ in dem einigen Jesu/ deß lebendigen Gottes/ und der Jungfrawen Mariae Sohn widerumb könne und müsse gesucht und gefunden werden."

115 Ibid., Aviiv: "Im Fall is aber der wille Gottes nicht sein solte/ daß mir die grosse Geheimnüssen/ und unerschöpffliche Schätz/ welche euch von Gott dem Herren/ als seinen beliebten und geheimen Dienern/ anvertrawet worden/ noch zur zeit offenbart unnd mitgetheilt werden."

116 Ibid., Aiiir ${ }^{r}$-Aiiiv: "Fürs dritte/ so hab ich mit grosser Verwunderung angehört/ das ewer hocherleuchte Vater weillant Fr. C.R.C. Christseligster Gedechtniß der minutum mundum perfecte absolvirt hinderlassen/ von welchem ich als ein unerfarner anderst nichts zuschreiben oder zu urtheilen weiß/als dz ich auß dem Liecht der Natur vermerck/ daß ein solches Geheimnuß und mysterium in der Natur sein müsse [...] wie auch der Spruch deß uhralten Egyptischen Magi Hermetis Trismegisti gnugsam an/ das nemlich das ob ergleich sey dem undern/ und è contra, daß so unden gleich dem so oben/ sey allein was in dem einen ist actu, findet sich im andern potentia."

117 Ibid., Aiiiv: "Aber wie viel sind deren/ denen es ganz unglaublich ist/ das ein Mensch solle durch Weißheit zu wegen bringen/ daß er Himmel und Erden in seiner Faust tragt."

118 Weigel, Gnothi seauton, 15: "Und endlich die newgeborne Menschen haben auch ihre Speise/ unnd Tranck/ das ist das Fleisch/ und Blut Christi/ zum Himmel uns ewige Leben/ 
C.H.C., who explicitly drew on the Fama as well as on Paracelsus, insisted that because of this analogy, humans could comprehend the one world through the study of the other. By means of what he named the "minute world" (the microcosm), which was like a "compendium" and a "living image of the entire universe in which all Rotae of the world are contained," one could understand and investigate all of nature. Like Haslmayr and Lull, he viewed the Rotae as keys to grasping the entire natural reality and he understood them as internal powers through which nature can be opened - a process that he claimed had previously been described by Paracelsus. ${ }^{119}$

Such means to complete understanding of the natural and divine worlds were also expressed in the anonymous reply by a certain I.B.P. ${ }^{120}$ The past age, I.B.P. argued, had been an age under the rule of the Antichrist, with deception and false opinions abounding. ${ }^{121}$ He now expected the arrival of a new earthly period, which he associated with another traditional character from the canonical literature, namely Elijah. During the new Elijan age, the once corrupted truth will become available, as the "Elijan spirit" will return

auff daß nun der Mensch ein Begriff were/ unnd ein Beschluß aller Geschöpffen/ und gleich als ein Centrum und Punct aller Creaturen/ auff welchen alle Creaturen sehen solten/ und ihn vor einen Herrn erkennen/ hat Gott wollen den Menschen nicht auß nichtes/ sondern auß etwas/ das ist auß der grossen Welt formieren/ dann einen solchen gewaltigen Schöpffer haben wir/ daß er diese grosse Welt fassen kan in eine Faust/ das ist/ in den Microcosmum beschliessen/ etc." Weigel's book is inspired by Paracelsian terminology.

119 C.H.C. Sendschreiben oder Einfältige Antwort, Aiiiir: "Aber wie ist mir Einfalitgen/ und der Weißheit ganz unerfahrnen müglich/ von solchen hohen Geheimnüssen und Wunderwercken Gottes gnug würdiglich zu schreiben/ sintemal ich gänzlich dafür halte/ das mit diesen minuto mundo als eim Compendio und lebendigen imagine totius vniversi inn dem alle Rotae mundi begriffen/ könne alles das jenige/ so in der ganzen Natur zuerfaren ist/ eigentlich ergründet/ und außgeforschet werden/ wie dann der hocherleuchte Wunderman theoph. Paracels. in seiner Mathematica adepta darvon auch Anregung thut." The "mathematica adepta" is one branch discussed in the Astronomia Magna: Paracelsus, Astronomia Magna, I, 12; 4-444, and concerns mathematical relations. Cf. Paracelsus, Opus Paramirum, I, 9; $39 \mathrm{ff}$.

120 I.B.P., Sendschreiben an die Christliche Brüdern vom RosenCreutz, 102, 111, 117. Although the reply was appended to the Confessio (Gdańsk, 1615), this text was solely a reply to the Fama.

121 I.B.P., Sendschreiben, 112: "Erstlich aber dancke ich Gott dem Allmachtigen von ganzem Herzen/ daß er diese so vortrefflicher weiser Leute auff Christo und der Warheit gegründte Fraternitet/ in dieser letzten grundsuppen den finsteren betrieglichen Welt/ und bey vollem Lauff deß Antichristischen Seculi, hat erwecket und auffkommen lassen." Cf. ibid., 109. This verdict was shared by another letter, which was written by a certain M.V.S. A.Q.L.I.H. from Austria, but it is of less interest. The author of this text, too, claimed that the world had been filled with misery, until the Rosicrucians, sent by God, had come with their words of consolation and their philososophical canon: M.V.S. A.Q.L.I.H., Ein ander Sendschreiben, 116-121, especially p. 118. 
truth to the world, "confirm" the Rosicrucian fraternity, and be "a teacher of all divine and human wisdom."122

According to I.B.P., the Rosicrucian brethren had revealed "the divine wisdom and knowledge of all natural things"; 123 they had provided the reader with "knowledge of God and of nature" and had "made public many secrets in all arts and sciences." He argued that the Rosicrucian axioms, Rotae, and Proteus had to be put into use, because the fundamentals of the wisdom of God and of nature were still unknown. ${ }^{124}$ All these instruments had been mentioned in the Fama as being contained in the Rosicrucian library; the book of the axioms being the most important, the Rotae the most artistic, and the Proteus the most useful. ${ }^{125}$ I.B.P. desired to use these books to improve the knowledge of nature and the divine. It remains unclear what exactly the Proteus refers to in the Fama, but one suggestion may be that it derived from Heinrich Khunrath's On Primaterial Chaos (1597). In this text, Khunrath writes about Proteus in reference to the sea god Proteus. He explains in alchemical terms that it is "catholic mercury" and has power over all things. ${ }^{126}$ For Khunrath, catholic mercury, and thus

122 I.B.P., Sendschreiben, 109-110: "Ich geschweige jetzunder/ daß lang zuvor verkündiget worden/ wie diesem unserm Helianischen seculo die zum theil ganz verlohrne/ zum theil mit vielen irrigen meynungen verderbte Warheit/ wiedergegeben werden soll [...]. [Gott wird vertreiben und umbringen] mit den Geist seines Mundes/ alle Dunckelmeister/ als obgesagte Göttlicher Warheit und ewigen Liechtes Feinde/ welche Krafft denn deß Helianischen Geistes in Wiederbringung der Warheit/ ewre heilige Fraternitet bestetiget/ als welche eben derselbe Helianische Geist/ ein Lehrmeister aller Göttlichen und Menschlichen Weißheit/ regiret und führet."

123 Ibid., 110: “[...] sondern das auch die Göttliche Weißheit und Erkändnüs aller natürlichen Dinge/ jetzund in ewer Fraternitet von Gott geoffenbahret [werde]."

124 Ibid., 102-103: "Nicht weiniger weißlich als Christlich ist von euch geschrieben/ liebe Brüder vom RosenCreutz/ daß die zwo vornehme Staffeln Göttlicher Weißheit/Gottes nemblich unnd der Natur Erkandtnüß/ fast auff höchste/ durch gemeinen Lauff und ubung gebracht/ und zwar viel Heimligkeiten in allen Künsten und Wissenschafften offenbar gemacht worden/ es aber doch noch an vielem mangele/ und die axiomata Rotae mundi \& Protei, noch unberühret stehen/ und der Kern so wol in Göttlicher Weißheit als in der Natur Erkäntnüß/ für den Schalen nit habe können erkandt werden."

125 Fama, 110.

126 Khunrath, Von Hylealischen Chaos (1597), 220: "Wie nun alleine EIN Weldanfangs Hylealischer Mercury Catholicus ist/ Allgemeiner NATUR/ daraus unser Chaos auch gezeuget/ also ist gleich wie desselben auch unseres cHAOs (dieweil es ist jenes ebenbild) ein Catholische oder Allgemeine NATUR/ die nach lehr des Philosophi, in jedem gradu Philosophischer arbeiten sich verkehret und vergestaltet in viele und mancherley wesen/ arten und gestalten: Und ist unser Mercury Catholicus (aus Krafft seinen Allgemeinen Fewerfunckens des LiCHTS der NATUR) zweiffels ohne PRotevs, der uhralten Heidnischen Weisen Meer Abgott/ der die Schlüssel zum Meer/ und wie oRPHEus lehret/ Gewalt vber alles hat $[\ldots]$." 
Proteus, was a general nature or ethereal spirit which permeates everything in the world. This "universal Proteus" was known to true philosophers only, that is, to true alchemists. ${ }^{127}$ In this sense, Proteus, as a power over and embedded in all things, would indeed be useful in order to acquire insight into hidden mysteries. The Proteus understood in this way could help make hidden knowledge explicit, as I.B.P. hoped it would.

The revelatory implications of the manifestos were also discussed by G.A.D., the author of the fourth anonymous text appended to the Confessio. He replied to both the Fama and the Confessio. His letter is dated November 1614, which was after the publication of the Fama but before the Confessio had appeared in print. Several months earlier, in July 1614, August von Anhalt had reported that the Confessio had not yet come to light, that is, into his possession. He presumably knew of the Confessio because of its mention in the Fama, and his reference to it was the first time that the Confessio was mentioned in any text other than the Fama. Two months later, in September 1614, August described that he had seen a manuscript edition of the text, which he had received from Widemann. ${ }^{128}$ Again two months later, in November 1614, G.A.D. referred almost verbatim to a passage in the Confessio, which suggests that, if the dating is correct, this Rosicrucian manifesto also circulated in manuscript form in a clandestine manner and through underground networks before its eventual publication. ${ }^{129}$ This gives the impression that this author was acquainted with either August von Anhalt, or in any case with someone close to the Prince, because otherwise he could not have had the text in his possession so soon afterwards.

What is striking about this text is its continual copying from the pseudoParacelsian Apocalypse of Hermes, and it thereby links the Rosicrucian perennial philosophy to (pseudo-)Paracelsian motives. By reading the manifestos in a pseudo-Paracelsian manner, G.A.D. took the Rosicrucian brethren for Paracelsians. But whereas Haslmayr had understood Paracelsianism religiously, as a sacred gift from God, G.A.D. - in line with the other anonymous texts-associated Paracelsianism particularly with alchemy, medicine, and restored Adamic purity.

G.A.D. referred to the Confessio's passage about the return of "truth, light, and dignity" verbatim, and identified the return of "wisdom, light, life, and

127 Khunrath, Von Hylealischen Chaos, 222: "Dencke diesem Theo-Sophice nach; und lerne den Proteum Universalem recht erkennen."

128 Gilly, "Iter Rosicrucianum," 76.

129 About the Confessio and its possible circulation in manuscript form, see: Gilly, Cimelia Rhodostaurotica, 73 . 
splendour," like the German Confessio, with the returned order of Paradise. ${ }^{130}$ This does not imply that Paradise itself will return, or that the new period was identical to the time in Paradise, but that the imminent conditions will be similar to the prelapsarian order. With this notion of an imminent return of the prelapsarian state of affairs, G.A.D.'s reply was evidently not primarily influenced by Haslmayr's often printed Answer, but remained in contents close to the Confessio.

G.A.D. explicitly addressed the implication that the consequences of the Fall have been annulled. He argued that the sin of the first human couple, which had resulted in the Fall, had brought about a terrible condition on earth, but with the Rosicrucian manifestos this condition was now coming to an end:

Thereupon the miserable condition of our lives, in which we were landed because of the Fall of our first parents, will be brought to an end, everything will be relieved from the lies and darkness and brought back to light and rectified..$^{131}$

The Confessio had hinted at the idea that the consequences of the Fall had been reversed and nullified, and this idea had been suggested by the author of the Preface, but no one had as yet stated it as explicitly as G.A.D. now did. Of course, only when original sin was eliminated could original splendour be restored.

The expectation that paradisiacal conditions will be restored is also expressed in G.A.D.'s discussion of long life, an expectation that was in keeping with the Apocalypse of Hermes. The Fama had mentioned the brethren's capacity to remain healthy, and Andreae had described Hess as having had a body free from disease. ${ }^{132}$ G.A.D. pointed out that long life had once been enjoyed by the Patriarchs, and that their "secret of secrets" still abided on earth. He claimed that Adam and the other Patriarchs "had received their bodily health and long life" from the powers of a treasure, which

130 See $n .131$ below.

131 G.A.D., Ein ander Sendschreiben, 123: “[...] und fürnemlich inn der Confession außdrücklich vermeldet wird/ daß Gott der HErr beschlossen/ dieser verderbten Welt noch einmal vor irem interitu und letzten Untergang/ eben ein solche weißheit/ Liecht/ Leben und Herrligkeit wiederfahren zulassen/ wie anfenglich der erste Mensch im Paradeiß gehabt/ bin ich dadurch in diese erwünschte Gedancken gerahten/ es möchte alsdenn dem jämmerlichen Zustandt unsers Lebens/ in welchen wir durch den Fall unser ersten Eltern gerahten/ ein Ende gemacht/ alles von der Lügen und Finsternüß entlediget und wieder ans Liecht und zurecht gebracht werden"; Cf. Confessio (Gdańsk), 69.

132 Cf. above, section 2.4 and p. 199. 
as if it were the World Soul, is still to be found in all elemental creatures and moves all bodies, and as the ancient wise men had written that it was to be found in any thing, at any place, and in any time, it has in itself also the powers and effects of all creatures. ${ }^{133}$

The treasure is reminiscent of the world soul previously described by Ficino, and seems to be similar to Khunrath's Proteus. ${ }^{134}$ Inspired by the pseudoParacelsian Apocalypse of Hermes, G.A.D. described the ubiquitous treasure as

the sanctification and cure of all things. How miraculous and laudable is your [the treasure's] purity, in which lie hidden all true wealth and fertility of life together with the art of all arts, the entire world justly desires you, because you give joy to all who know you, you destroy all weakness, you lift up beauty to the loveliest degree and share often all that delights the people. ${ }^{135}$

Original Adamic life was restored, because body and world were purified and perfected. This treasure had a medical and purifying function, and was responsible for all that was good and beneficial, rendering all things holy because it possessed within itself and permeated, like the life-giving world soul, all aspects of the universe.

It comes as no surprise that G.A.D. also related this treasure to the philosophia perennis. Copying pseudo-Paracelsus, he explained that this treasure and unknown nature had once been known to Adam. It was revealed by the

133 G.A.D., Ein ander Sendschreiben, 124-125: "Ob nun wol dieser edle Schatz/ auß welches Kräfften/ Adam unnd die andere Patriarchen/ ihre Leibes Gesundheit und langes Leben gehabt/ je und allwege in der Welt blieben/ unnd auch noch gleichsam als die Seele der Welt/ in allen Elementischen Geschöpffen gefunden wird/ und alle Corper beweget/ wie denn daher die alte Weisen geschrieben haben/ daß er in einem jeden Dinge/ an einem jeden Orte/ und zu jeder zeit gefunden werde/ auch aller Creaturen Kräffte und Wirckungen in sich habe."

134 Cf., for example: Ficino, De vita libri tres, Lib III, p. 121, where he describes that the world soul is present and alive everywhere, cited in: Lüthy, "Centre, Circle, Circumference," 316.

135 G.A.D., Ein ander Sendschreiben, 127: "[...] wie dahere obgedachter Thephrastus [sic] nicht unbillich geruffen: O du Geheimnüß aller Geheimnüsse/ unnd aller geheimen Dinge Heimligkeit/ Ja aller dinge Heiligung und Gesundmachung/ wie wunderbarlich unnd löblich ist dein Reinigkeit/ darin alle ware Richthumb und Fruchtbarkeit deß Leben is sampt der Kunst aller Künste verborgen ligen/ billich begeret dein die ganze Welt/ denn du allen die dich kennen/ Frewde gibst/ alle Schwachheit zerstörest/ die Schönheit auffs lieblichste erhelft/ unnd alles was dem Menschen wolgefellet/ heuffig mittheilest." Cf. PseudoParacelsus, Apocalypsis Hermetis, 670. 
Holy Spirit first to Adam, thereafter only to the wise through diligent study. It was purposely obscured by philosophers to conceal it from the fools of the world, ${ }^{136}$ but was now once more revealed by the Rosicrucian brethren. ${ }^{137}$ Referring to the Apocalypse, the author argued that Paracelsus was one of the men who had investigated this precious treasure, having written of "the secret of all secrets." ${ }^{138}$ Paracelsus was thus explicitly identified as a figure professing original medical and alchemical knowledge, with his philosophy now incorporated into the manifestos. Whereas the restored Adamic knowledge, language, and order were a precondition for the general reformation according to the Rosicrucian manifestos, G.A.D.'s emphasis on the return of paradisiacal conditions rendered both the notion of a general reformation with all its political, social, and educational consequences as well as the apocalyptic array of lion or Antichrist superfluous.

In these anonymous texts Haslmayr's pessimism made way for optimistic prophecies about the restoration of Adamic knowledge and purity. They deviated from the views of the three main confessions because of the notion of divine illumination before the end and the optimistic tones of their announcements. Their authors took elements from the Rosicrucian call for a general reformation, but omitted their reformative context. Other apocalyptic ele-

136 G.A.D., Ein ander Sendschreiben, 125-126: "So hat es doch dem Allmächtigen Schöpffer also gefallen/ daß er einer unkendtlichen Natur were/ unnd von der Welt nicht begriffen würde/ wie er denn allein durch Eingebung deß heiligen Geistes unserm ersten Vatter Adam von oben herab/anfenglich/nachmals aber durch fleissigen Unterricht/ quasi ex manu in manum, den Weisen geoffenbahret und gegeben worden/ welchen die Philosophi nachmals mit frembden dunckelen Worten/ unnd verblümbten Reden also verborgen haben/ daß er den Narren wol verdeckt bleiben muß und sehr wenigen in dieser Welt bekandt werden kan." Cf. Pseudo-Paracelsus, Apocalypsis Hermetis, 668.

137 G.A.D., Ein ander Sendschreiben, 127-128: "Weil denn nun hochweise Brüder deß löblichen RosenCreutz/ inn Ewer [...?] Fama unnd Confession die Vertröstung menniglich geschehen/ da diese und andere Schätze der Weißheit ins künfftig ans Liecht gebracht und meniglich bekandt gemacht werden sollen/ [...] Ihr O allerseligen Männer werdet auch mir diese Gunst [?] widerfahren lassen/ daß ich in ewre kundschafft gerahten/ und etwan eines kleines Fünckleins ewrer Weißheit theilhafftig werden möge/ wenn mi rein solches wiederfahren kondte/ wolte ich mich für glückselig halten und mir nichts liebers in dieser Welt wünschen oder begehren." Due to the binding some words are partly illegible.

138 Ibid., 123-124: "Ich hab etwan hiebevor zum offternmahl mit Verwunderung gelesen/ was der hocherleuchte Theophrastus Paracelsus in seiner Apocalypsi geschrieben von dem Geheimnüß aller Geheimnussen/ welches der allerweiseste Hermes, das wahre ohne lügen/ unnd das gewisse deß aller gewissesten: Andere aber/ das beste unnd höchste so under dem Himmel mag gesucht werden/ genandt haben [...]." The passage is copied almost verbatim from: Pseudo-Paracelsus, Apocalypsis Hermetis (Zetzner, 16o3), vol. 2, 668. Cf. also: Paracelsus, De secretis secretorum theologiae, II, 3; 165-232. 
ments present in the manifestos, such as the lion, the Antichrist, and the pseudo-millenarian expectations, which had still played a role in Haslmayr's Answer, were now largely lost to sight, and the manifestos were almost exclusively read as harbingers of original wisdom, although each of these anonymous authors emphasised this in a different way.

\subsection{The Rosicrucian Study of Alchemy and Medicine}

When it comes to alchemical and medical endeavours, the case of the famous alchemist and physician Michael Maier (1568-1622) is particularly instructive, albeit very different from the authors analysed in the previous section. Maier had already worked as a surgeon and physician before he matriculated in medicine at the University of Basel in the late sixteenth century. He then worked from 1609 until 1611 at the court of the emperor Rudolph II as physician-inordinary. Rudolph II granted him the noble title of count palatine. ${ }^{139}$ From 1618 onwards, several years after the emperor's death, Maier became affiliated with the court of Moritz von Hesse in Kassel, where the manifestos had been printed, Raphael Eglin worked, and Maier pursued alchemical and medical labours. ${ }^{140}$ He remained a Lutheran all his life, but also defended the Rosicrucian brethren and their fraternity on multiple occasions.

In 1616, just one year after the Confessio had been printed, Maier became interested in the Rosicrucian material. ${ }^{141}$ Over time, he became increasingly excited about the Rosicrucian manifestos. In his Silence after the Clamour (1617), he defended the Rosicrucians against slander inflicted upon them, and discussed at length secrets of nature and the panacea in the possession of the fraternity. ${ }^{142}$ By the time he published his Golden Themis (1618), he had become a fervent supporter of the brethren of the Rose Cross. ${ }^{143}$ The title of this work refers to the Greek Titaness Themis, known for her councel and authority on divine law. In this work, Maier defended the six laws or rules of the fraternity established in the Fama. ${ }^{144}$ The following year saw the publication of

139 Hubicki, "Michael Maier," in Dictionary of Scientific Biography vol. IX, 23-24. On Maier, see especially: Kühlmann and Telle, Der Frühparacelsismus, vol. 3, 31-32, 1241-126o; Tilton, Quest for the Phoenix; Nummedal (ed.), Furnace and Fugue.

140 On Maier at the court in Kassel: Moran, The Alchemical World of the German Court, 102-111.

141 Tilton, Quest for the Phoenix, 114.

142 Maier, Silentium post clamores (1617).

143 Idem, Themis aurea (1618).

144 These laws were: 1) not to practice any other profession than to cure the sick for free; 2) to wear the clothes of the land in which the brethren were living; 3) to return each year 
Discovered Truth (1619), in which Maier further discussed the Rosicrucian cause, so that by this time he had become one of the most famous defenders of the Rosicrucians. ${ }^{145}$

Maier was a well-known alchemist, and in both Golden Themis and Discovered Truth he related the Rosicrucians' efforts to chemical matters specifically. Like Haslmayr, he praised the Rosicrucians for their divine gifts, but unlike that Paracelsian theosopher, he emphasised one divine gift present in their fraternity in particular, namely the "unique gift of chemistry." While discussing their revelations, he prioritised two elements from the Rosicrucian manifestos above all others, namely: 1) the brethren's alchemy and medicine, which he decoupled from their call for a general reformation; and 2) their announcement of the return of divine gifts, which he interpreted in a specific, chemical, way. According to him, chemistry

had among them once been assumed and established as the foundation of the entire fraternity and still serves as its foundation, because if this is true (as they themselves have revealed), this is to be counted not the last among the true and good discoveries of Germany, but primordially, which is to be estimated not as the vile art (as the scoffers claim) of making gold, but as the greatest of God's earthly gifts. ${ }^{146}$

Maier referred to the Rosicrucians' comments on transmutational alchemy. The brethren had not rejected this art entirely, but had clearly made it subordinate to their other arts and sciences and dissociated it from the making of gold. Maier, an alchemist, was not hindered by the secondary position of alchemy in the manifestos, and understood the Rosicrucians first and foremost as chemists. He used the word "chymia," chemistry, while discussing this art, so as to emphasise that it was not to be practised for the making of gold and the mundane benefits it might provide. As the Confessio had already announced, alchemy was a gift from God when it was used for medicine and the

to Christian Rosencreutz's house named "Spiritus Sanctus"; 4) to each recruit a successor; 5) to carry the sign "R.C." as their seal; 6) that the brotherhood shall remain secret for 120 years; see: Fama, 106-107, 113, 119, and the Introduction.

145 Maier, Verum inventum (1619).

146 Ibid., 221: "Nihil autem hoc loco dicturus sum de illorum variis artibus ex naturae fontibus deriuatis, at saltem de vnico illo Chymiae dono, quod apud illos pro fundamento totius Fraternitatis olim habitum \& constitutum est \& adhuc habetur; quod si verum est (sicut se patefecerunt) est hoc ex Inuentis Germaniae VERIS \& Bonis non postremum, sed priori ordini annumerandum, quod non pro vili arte (vt nasutuli indigetant), faciendi aurum, sed pro maximo Dei ex terrenis hisce Dono aestimandum erit." 


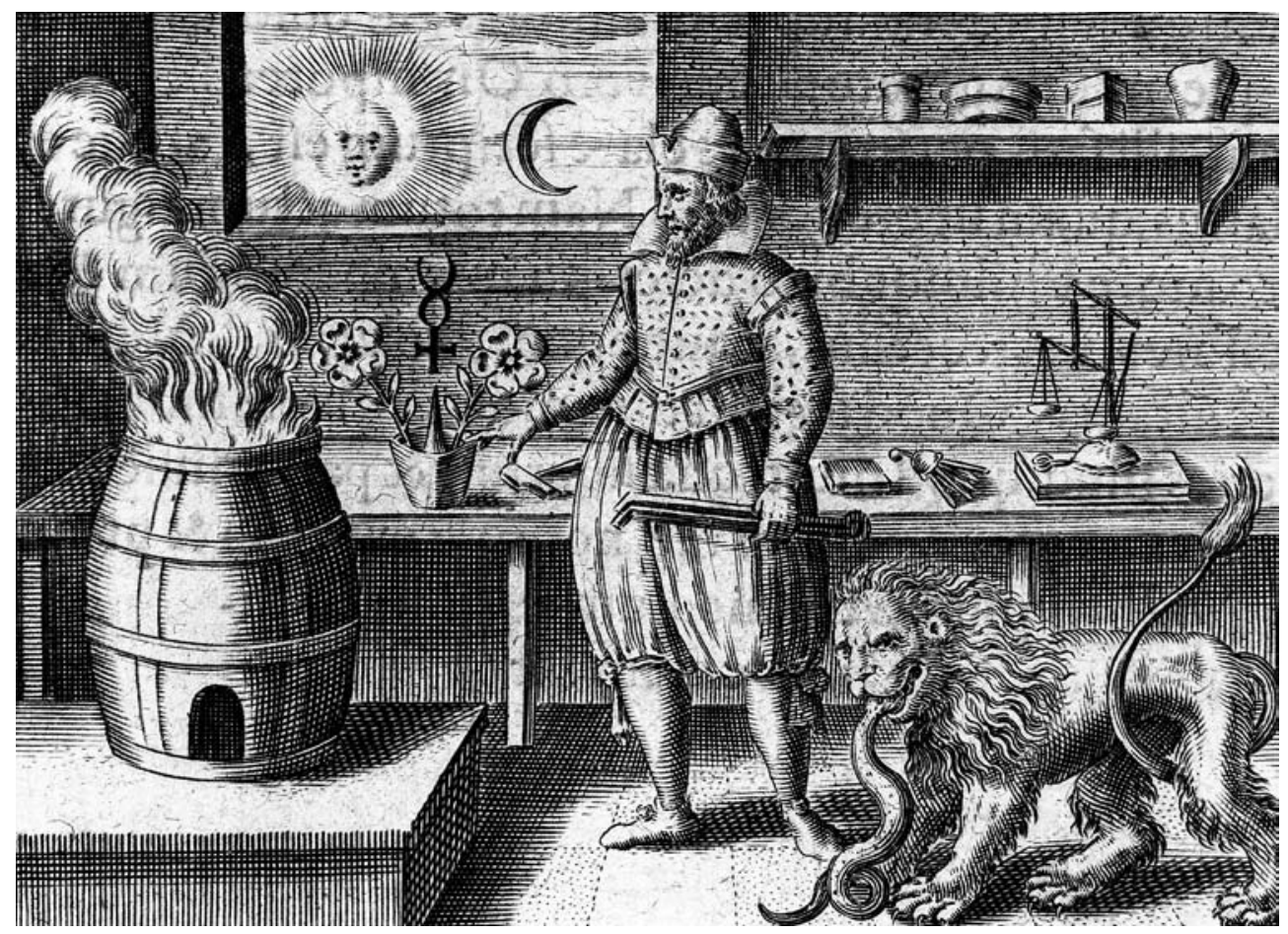

FIGURE 10 Michael Maier, Tripus aureus, "The Twelve Keys," attributed to Basil Valentine, describing the creation of the Philosophers' Stone. Wellcome Collection

disclosure of secrets. ${ }^{147}$ Maier drew on this passage from the second manifesto and stressed that the brethren were divinely inspired as they practised an art granted by God. ${ }^{148}$

In alchemy, gold was not merely a metal but could signify purity, wisdom, perfection, and health. It could be created with the philosophers' stone, which could be used for rejuvenation or for healing in general. It seems that Maier used alchemy primarily for medicinal purposes and he took the Rosicrucians for chemical and medical heralds. He emphasised the first rule of the Rosicrucians, which states that the brethren were first and foremost physicians. ${ }^{149}$ Maier, especially in Golden Themis, discussed this rule at great length, arguing

147 On this, see above, p. 122.

148 Cf. Maier, Verum inventum, 237b: "Fratres nempe R.c. esse Dei donorum possessores: Hoc enim ipsi aperte in suis libris fatentur"; ibid., 240: “[...] Ex quibus vel minimum sufficit ad demonstrandum Fratres R.c. esse aurifico Dono à Deo ornatos: Vbi enim rerum testimonia adsunt, verborum vix requiri videntur amplius." Because there is no page 236 , but two pages numbered 237 , the second page 237 is referred to as $237 \mathrm{~b}$.

149 Cf. Fama, 106. 
that medicine was an "excellent art and profession" practised by the brethren. ${ }^{150}$ The Rosicrucians' chemical art was used above all to cure the sick:

If the brethren of the R.C. have had this art or chrysopoeia (I will not say anything about their other secrets) in their possession from the first author for 200 years and more to this point and until even now, then they are themselves loved by God and are worthy of all respect by humans, they are the flower of our time, the apex of knowledge, the summit of glory, the sanctuary of true piety, the light of all doctors, and the pillar of the sick. ${ }^{151}$

This chemical art should be used specifically to "remove almost all diseases from humans" and return "health to the human body." But the Rosicrucians, as pious chemical physicians, were also capable of purifying all metals and transmuting them "into the most perfect gold." Here, Maier used again a medical term, namely when describing that the brethren "remove leprosy from all imperfect metals and banish the cause of all corruptions."152 It was not uncommon to refer to the impure metals as "lepers" to signify the process of purification that was needed, ${ }^{153}$ but this medical analogy puts further emphasis on the importance of the healing process. To Maier, both bodies and metals should be cured. Medical chemistry, he concluded, was the highest and purest of all sciences, and the Rosicrucians' treasure worked as a panacea. He claimed that "among the secrets of the society of the Rose Cross in Germany also the universal medicine" could be found, and it was revealed through the Fama and Confessio. ${ }^{154}$

150 Maier, Themis aurea, 39: "Tam sancta ergo, tamque preciosa \& praelustris cum sit Medicinae professio, hinc Fratres R.c. non immerito huic palmam \& principatum obtulerunt inter tot artes \& scientias, quibus abundant \& clarent." Cf. Fama, 106.

151 Maier, Verum inventum, 224-225: "Quod si Fratres R.c. hanc artem siue Chrysopoeiam (ne quid de aliis arcanis dicam) in possessione inde a primo authore per ducentos annos \& amplius huc vsque \& etiamnum habeant, ipsos esse Deo dilectos \& omni Reuerentia hominum dignos, florem nostri aeui, apicem scientiae, culmen gloriae, asylum verae pietatis, lumen doctorum omnium, \& columen aegrorum."

152 Ibid., 222: "Iampridem ante multa secula insonuit hic rumor in auribus vulgi nec non doctorum, \& ex scriptis quamplurimis, quae ad non peruenerunt, antiquorum innotuit, esse in potentia Naturae absconditam aliquam medicinam, quae vt ab hominibus fere omnes morbos profligat, sanitate in corpus humanum reducta, sic quoque a metallis omnibus imperfectis lepram \& corruptionis causam tollat \& abstergat, iis in aurum perfectissimum transmutatis."

153 Nummedal, Anna Zieglerin, 105.

154 Maier, Silentium post clamores, 32: "Daß under den Geheimnussen der Societat R.c. in 
Maier took alchemy for a divine and ancient art that previously had been practised by Moses. The Rosicrucians, according to him, had possessed this art ever since Christian Rosencreutz founded the fraternity. It was similar to what has come to be known as Mosaic physics, because Maier argued that the art agreed with an original, Mosaic, and pious physics. ${ }^{155}$ Medicine, therefore, also had ancient origins, because "the medicine of the brethren is the spark of Prometheus, [which he] received with the help of Minerva from the sun as a borrowing, and delivered to the humans in a stick."156 This fire, Maier explained, spread throughout the world and could be used to prepare medicines for both body and soul. 157

The secret of the universal medicine had been in the possession of "several hidden secret colleges" of the far past, and was transmitted orally from generation to generation in Egyptian, Greek, Persian, and Arabic societies. ${ }^{158}$ Two of these colleges were located in Damcar and Fez, where Christian Rosencreutz had been introduced to these secrets. ${ }^{159}$ Such a transmission of pious wisdom was in the tradition of the philosophia perennis, as these secrets were known to a few people in the distant past and were "in this our time" brought to light in the Rosicrucian manifestos. 160

Teutschland/ auch die Universal-Medicine/ und nach Gottes Erkandtnus das höchste Gut begriffen seye." Cf. ibid., 40-41, and chs. 7 and 8.

155 Idem, Verum inventum, 230: "interim, [detractores \& calumniatores] dicant, quo artificio Moses aureum illum vitulum combusserit in pulveres, absque Chymiae opera, \& dederit Israelitis in potu: Ego hic infero, Qui potest aurum comburere in pulueres, Chymicus est: At illud Moses fecit: Fuit ergo Chymiae non ignarus." The passage refers to Exodus 32, where Moses is described as burning the golden calf made by the Israelites in his absence.

${ }_{15} 6$ Maier, Themis aurea, 40-41: "Et ut verum fatear, Fratrum Medicina est igniculus Promethei, auxilio Minervae, à Sole mutuo acceptus \& ad homines delatus in ferula [...]."

157 Ibid., 41: "Ignis est propagatus per totum orbem, eoque Medicinae praeparatae, quae tam animo, quam corpori opem praestant."

$15^{8}$ Maier, Silentium post clamores, 50-51: “[...] etliche verborgene heimliche Collegia." On the ancient colleges across the world, see: ibid., $5^{2-78}$.

159 Ibid., $77-78$.

16o Ibid., 84: "Wann dann die Gesellschaft R.c. nunmehr viel Jahr lang/ ihren selbst Bekantnus nach/ biß anhero verblieben/ hat sie in solchem auff Gottes Ehre/ und der Menschen Wolfahrt gesehen/ wann sie dermal eins soll geoffenbaret werden/ wie dan zu dieser unserer Zeit geschehen." Cf. ibid., 87: “[...] solche Offenbarung dieser Zeit geschehen müssen/ zu der zeit/ nemlich/ wann deß ersten Urhebers derselben [the Rosicrucian fraternity] /verborgenes Grab gefunden/ und eröffnet worden." Maier emphasises, however, that neither all treasures will be revealed nor that all arts will become perfect; see: Ibid., 21. He presumably arrives at this conclusion to avoid portraying the Rosicrucians as revolutionaries; see below, p. $258 \mathrm{f}$. 
Although Maier combined chemistry and medicine, he did not consider himself a Paracelsian physician. He rejected Paracelsus' claims to uniqueness, and only used Paracelsian cures to complement many other efforts in medicine. ${ }^{161}$ The chemical medicine of the Rosicrucians, he believed, was older than that of Paracelsus. The medical practice of the Rosicrucian fraternity was not the result of novel human efforts or of a reformation, but of the restoration of an old medicine-which meant that the Rosicrucians were restorers of an ancient iatrochemical practice.

For Maier, the Rosicrucians restored ancient knowledge, but they did not set out to reform the world. Their task was to reveal original knowledge, but they could do so only in an incomplete and limited way. Maier specifically claimed that the Rosicrucian brethren did not have a general reformation in mind. Opening his twentieth chapter of the Golden Themis, he explained " $[t]$ hat the brethren R.C. do not await or aspire to a reformation in the world, in religion, in the conversion of the Jews, in politics [...]." He argued that a general reformation was the aim and intention of "Anabaptists and enthusiasts," whom he, like all Lutherans, dismissed. ${ }^{162}$ Surely, he protested, the Rosicrucians could not possibly be seen as one of those disreputable sects. His argument was that "neither does the fraternity R.C. ever declare such [a reformation], nor will it be elicited from their writings." And even though the Fama was appended to a text about a reformation of the world, namely chapter 77 entitled General and Universal Reformation of the Entire World of the satirical work News from Parnassus, ${ }^{163}$ Maier insisted that this Italian text had been composed earlier and had no relation whatsoever to the contents of the manifestos. ${ }^{164}$ Instead

161 Maier, Themis aurea, 95: "Bona medicamenta, quae habet, non recuso, sed monarchiam eius, \& tot plaustra calumniarum in omnes alios (se vno excepto) medicos congesta \& effusa, non agnoscimus pro rationalis hominis, nedum virtute praediti tecmyrio, vel insigni." Cf. ibid., 94.

162 Ibid., 187: "Si qui mutationibus Politiae, religionis, artium vel scientiarum suas cogitationes intentius infixerint, leuissima quaeque insectantur, vt id fiat, secundum voluntatem eorum: Hae causae fuerunt multorum in Rep. tumultuum, quibus delirae persuasiones non raro principium \& fundamentum praebuerunt, vt in Anabaptisticis \& Enthusiasticis motionibus nimis conspicuum euasit." For Luther's rejection of Anabaptists, see also: Williams, The Radical Reformation, xxiiff.

163 Cf. above, pp. 167-168.

164 Maier, Themis aurea, 188-189: “Nec n. Fraternitas R.c. eiusmodi vnquam asseruit, nec id ex eius scriptis eliciendum erit: Est quidem Reformatio totius mundi tractatu quodam Famae Fraternitatis adiuncta, quae nullo modo ad hanc referanda, sed veluti à Viro docto accepi, ex Italico idiomate ante hac translata, quasi vnius nouitatis aut sensus esset, cum Fama editi est." 
of preparing a general reformation, he claimed, the brethren were singularly dedicated to truth and justice. ${ }^{165}$

According to him, there had been a reformation of the arts in the past, which was desired by Christian Rosencreutz prior to Luther's Reformation, and was carried out in Germany since 1400 "in this final age" by figures such as Agricola, Erasmus, Luther, Melanchthon, Paracelsus, Regiomontanus, Copernicus, and Brahe. ${ }^{166}$ Any further reformation of the arts and sciences was unnecessary. As for the further necessary reformation of religion and politics, it could only be brought about by divine intervention: "But the reformation of all heresies is rather a matter for God than for man, and it is not pursued by the brethren, even though it is hoped for by all good men."167 Whereas the authors of the manifestos had clearly planned to reform these fields, Maier denied with absolute certainty that this had been their intention.

This was consistent with his orthodox Lutheranism, according to which there was no future time on earth; any reformation would be futile; change could only be brought about by supernatural beings but not by humans; and perfection could not be realised on earth. Accordingly, Maier explained that the end of the world was nigh; ${ }^{168}$ that no further reformation would take place; that the intellect "can only be illuminated by God"; that only God, not the Rosicrucians, could bring about mental illumination; ${ }^{169}$ and that most, but not all, diseases can be removed from human bodies. Maier evidently intended to protect the Rosicrucians against any charges of heresy, enthusiasm, or Anabaptism, and to make the manifestos acceptable to Lutheran sensibilities.

165 Ibid., 186, title of chapter 20, explaining the contents of this chapter: "Quod Fratres R.C. nullam reformationem in mundo, religione, Iudeorum conversione, Politia, qualem Enthusiastae quidam etiam ex sacris adducentes ad id probandum sententias, somniant, sperent aut intendant, at veritati \& iustitiae se semper addictos testentur."

166 Ibid., 189: "De reformatione artium ibi quid legitur, tentata à primo eius ordinis authore, ante ducentos \& 17 fere annos, nempe circiter A.c. 1400. Et sane tum temporis Reformatione quadam indiguerunt, quam nonnullae earum acceperunt hoc vltimo seculo, vt caeteras gentes taceam, in Germania, à Rudolpho Agricola, Erasmo Roterodamo, tanquam duobus luminibus omnis bone literaturae à D. Luthero, Philippo Melanchtone, Theoph. Paracelso, Ioh. Regiomontano, Copernico, Tychone Brahe, \& aliis innumeris [...]."

167 Ibid., 189-19o: "Nec dubium est, adhuc maiorem Reformationem posse institui ab iis, qui naturae latebras magis cognitas habent, quam alii: Ex his nihil de Repub. aut religione induci potest [...]. At Reformatio omnium heresum potius ad Deum, quam hominem spectat, nec à Fratribus affectatur, licet ab omnibus bonis speretur."

168 Maier, Silentium post clamores, 9o.

169 Idem, Themis aurea, 19o: "Illuminatio intellectus hic magis, quam coactio voluntatis valet: Haec enim ab homine vt cogi nequit, sic ille à solo Deo illustrari saltem potest: Ille vnus dat posse \& velle: ad quem hanc Reformationem referimus." 
He did not want the Rosicrucians to seem like revolutionaries-they were restorers but not reformers. Although he shared with the anonymous responses an interest in apocalyptic revelations of the alchemical and medical arts, he completely deviated from theirs - and the brethren's - promises and hopes which were rejected in the orthodox Lutheran literature. With his interpretation, Maier was perhaps trying to save the Rosicrucian brethren from criticism by scholars such as Andreas Libavius, who had published his attack on the brethren several years before Maier published his Golden Themis. ${ }^{170}$

\subsection{The Reform of Medicine and Sciences}

Again very different were the views expressed by several other scholars, who did not steer clear from criticising established learning and promoting a reform programme. So far, we have come across elements related to the Rosicrucians' reformation and its apocalyptic context, but only now will we encounter, albeit in a limited way, the theme of the reformation so eagerly desired by the Rosicrucians.

It should first be mentioned that the anonymous pamphleteer C.H.C. not only worked in the tradition of the philosophia perennis, but also discussed the Rosicrucian reformation and the active involvement therein of human agency. He linked the outpouring of original wisdom to the reformation of the arts specifically:

First with regard to your intended reformation [of] the faculties and arts, I can communicate with truth that I have desired such a reformation from the bottom of my heart, because by investigating the truth I have often sensed and concluded how sick and flawed several [faculties and arts] are. ${ }^{171}$

C.H.C. referred to the contemporary conservative academic programme, which Christian Rosencreutz, in the Fama, was said to have already wanted to cure one hundred years previously.

\footnotetext{
170 On Libavius, see below, section 5.1.

171 C.H.C., Sendschreiben oder Einfältige Antwort, Aiiv: "Was nun fürs erste ewere fürhabende Reformation oder Faculteten und Künsten betrifft/ kan ich mit warheit außgeben daß ein solche Reformation volengst aus grund meines herzen gewünscht hab/ dieweil in Nachforschung der Warheit vielfaltig gespührt und befunden/ wie Krank und mangelhaft etliche seyen."
} 
C.H.C. may have been a physician, because he especially decried the poor status of the contemporary "art of medicine" and hoped for its improvement. ${ }^{172}$ C.H.C. claimed that "the great heap of physicians and doctors accomplish not just in the heaviest and most important diseases little or almost nothing, but they also cannot accomplish much of value in the minor and little concerns of humans, often because of a lack of a fundamental knowledge of their art."173 He rejected traditional Galenic medicine and used instead alchemically prepared cures. Medicine should be practised with the use of alchemy, that is, by means of a philosophical stone that could restore bodies back to health. Here, he differed from strict Paracelsian medicine, which worked with alchemically prepared substances from nature, such as herbs, plants, and minerals. C.H.C. instead wanted to use the stone that had been searched for by alchemists for centuries, believing as he did that it will function as a panacea. By means of the creation of the philosophical stone, alchemy "frees the human body from diseases and can preserve it in good health."174 Unlike Maier, C.H.C. saw in the medical profession of the brethren an example of the reformation of the arts called for by the Rosicrucians.

Hopes for a reformation of the arts and sciences were also expressed in a text that appeared around the same time, under the pseudonym Julianus de Campis. In spring 1615 , a short but influential reply to the Rosicrucian brotherhood was published, entitled Letter or Message to All Who Have Read Something by the New Brotherhood Called of the Order of the Rose Cross, or Also Learned From Others by Hearsay About the State of Things. ${ }^{175}$ The text is one of the best-known replies to the Rosicrucian brotherhood, not least because it was once published together with an edition of the Fama and the Confessio, but it

172 Ibid., Aiiv: “[...] Und aus dißmal kürze halben allein die Kunst des Arzney zum exempel anzuziehen/versehe [?] ich mich es werde niemand so unerfahren und unverstendig sein/ der da nicht wisse und verstehe/ wie schwach [...] es mit solcher herrlichen und fürtrefflichen kunst itziger zeit beschaffen sey." Some words are partly illegible due to the binding.

173 Ibid., Aiiv: "[...] sintemal der meiste hauff der Artz und Doctorn/ nit allein in den schwersten und wichtigsten Krankheiten/ wenig oder schier nichts prestiren/ sondern auch in den geringen und schlechten Anliegen der Menschen/ manchmal auß mangel gründliegen Wissenschafft ihrer Kunst/ nicht viel [...?] würdiges außrichten können.”

174 Ibid., Aiiir: "Was anlangt die Kunst des gold machens oder Lapidis Philosophici, bin ich seit vielen Jahren hero der meynung erwesen/ das dieselbe zwar in ansehung die zeitliche [?] Nahrung und notturfft dadurch reichlich zu wegen gebracht/ und der menschliche Cörper von kranckheiten erledigt und in guter Gesundheit erhalten werden kan [...]."

175 Julianus de Campis, Sendbriefff oder Bericht An Alle/welche von der Newen Brüderschafft des Ordens vom RosenCreutz genant, etwas gelesen/oder von andern per modum discursus der Sachen beschaffenheit vernommen. 
has long remained under-studied. ${ }^{176}$ It provides a clear interpretation of the Rosicrucians' programme and message.

Some historians have attributed this text to Julius Sperber (1540-1616), but his authorship has been called into question. Sperber was believed to have written about the Rosicrucians in About the Highest Treasures, published as the Echo in 1615, which gave rise to suggestions that he could have authored this Letter to the Rosicrucians as well. ${ }^{177}$ Since Sperber's About the Highest Treasures was actually written in 1597, naturally the Rosicrucians are neither mentioned in the original 1597 preface nor in the main body of the text. ${ }^{178}$ Only the second preface of 1615 referred to the Rosicrucian manifestos and the fraternity, but it is doubtful that this preface was written by Sperber himself. It refers in several places in the third person to the author of the subsequent text, About the Highest Treasures, which makes it more likely that it was written instead by the publisher or another related figure. ${ }^{179}$ Sperber himself had nowhere referred to the Rosicrucians.

Several scholars have subsequently pointed to the Dutch painter, engraver, and engineer Cornelius Drebbel (1572-1633) as the author of Julianus' Letter. The possibility that the pseudonym "Julianus de Campis" was used by Drebbel had already been considered by Haslmayr's friend Karl Widemann: "Julianus de Campis, otherwise named Cornelius Trebel: he dwells with the King of England. An erudite man, well-intentioned." 180 Recent authors have

${ }_{176}$ Fama Fraternitatis (Franckfurt am Main: Johannes Bringern, 1615). Julianus is mentioned in: Schick, Das ältere Rosenkreuzertum, 238-245, although his discussion is mostly about Sperber; and in Peuckert, Das Rosenkreutz, 5, 115, 124, 148, 157, who attributes the About the Highest Treasures (Echo) to Sperber. Further references to Julianus include: Yates, The Rosicrucian Enlightenment, 94, 96; Gilly, Cimelia Rhodostaurotica, 91; Snoek, De Rozenkruisers, 348-35o. The name of Julianus de Campis also appears in the image of the college in Mögling's Speculum, below a hand that carries a sword; see: Mögling, Speculum. For Mögling referring to Julianus, see below, p. 275 .

177 Colberg, Das Platonisch-Hermetische Christenthum, vol. 1 (1710), 121-131; Arnold, Unpartheyische Kirchen-und Ketzer-Historie, (1729), Th. II, B. XVII, C XIIX, 1126; Schick, Das ältere Rosenkreuzertum, 238; McIntosh, The Rosicrucians, 32; Wels, "Die Frömmigkeit der Rosenkreuzer-Manifeste," 202. On Sperber, see further: Ferguson, Bibliotheca Chemica, 391-392; Schick, Das ältere Rosenkreuzertum, 238-245; Peuckert, Das Rosenkreutz, 25-34; McIntosh, The Rosicrucians, 15-16; Åkerman, Rose Cross, 210, 212; Murase, "Paracelsismus und Chiliasmus," 127-152; Tilton, "The Rosicrucian Manifestos," 135-136.

178 Sperber, Von der höchsten/allerbesten unnd thewresten Schätze, prefixed by the title page Echo der von Gott hocherleucheten Fraternitet Lobl. Ordens R.C. Gilly doubts that Sperber was the author of this text; see: Gilly, Johann Valentin Andreae, 31.

179 An die Hocherleuchte Brüderschafft, preface to: Sperber, Von der höchsten Schätze, diiiv, dv ${ }^{v}$, dvi , dviir ${ }^{r}, c^{r}$.

180 Widemann, Sylva scientiarum, 723 , refers to a text he had received from a J. Oswald 
concurred with this identification. ${ }^{181}$ Most recently, also Drebbel's authorship has been called into doubt, and at least Gilly now points to the Tübingen scholar and friend of Andreae and Hess, Christoph Welling (1582-1661), as the author behind the pseudonym, although additional evidence for this hypothesis is still needed. ${ }^{182}$

The Letter written under the name of Julianus de Campis discussed at length the Rosicrucian call for reform. According to Julianus, the Rosicrucian texts had been misunderstood and mocked by many, ${ }^{183}$ because hardly anyone was acquainted with what he called "the true material" — that is, the materia prima of alchemy—that was studied by the brethren. ${ }^{184}$ Like the Rosicrucians, Julianus wrote his text under the presumption that a new time was imminent. He expected not the end of the world but a new period that allowed for radical change for the better: "The time will come, that the thoughts of many hearts will become public," although the Rosicrucian axioms will never be widely appreciated. ${ }^{185}$ In response Julianus took upon himself the task of explaining to the wider public the philosophy and true intention of the brethren.

Since the Rosicrucian brethren had called for an earthly reform, Julianus outlined a programme of change in philosophy and scientia. He, too, disassociated

from Montbéliard: "Julianus de Campis, sonsten Cornelius Trebel genanndtt; versatur apud Regem Angliae. Ain gelertter Mann. Wohlmainendtt," cited in: Gilly, Johann Valentin Andreae, 51. On Drebbel, see: Jaeger, Cornelis Drebbel en zijne Tijdgenooten; Snoek, De Rozenkruisers, 348-386; Keller, "Cornelis Drebbel (1572-1633)"; eadem, "How to Become a Seventeenth-Century Natural Philosopher."

181 Gilly, Johann Valentin Andreae, 51; idem, Cimelia Rhodostaurotica, 91; Åkerman, Rose Cross, 17; Snoek, De Rozenkruisers, $348-35$ o.

182 Gilly, "Las novas de 1572 y 1604 en los manifiestos rosacruces," 279-281; idem, "Khunrath und das Entstehen der frühneuzeitlichen Theosophie." Further evidence may be provided in Gilly's eagerly awaited history of Rosicrucianism, scheduled to consist of six volumes.

183 Julianus de Campis, Sendbriefff oder Bericht, Aiir ${ }^{\mathrm{r}}-\mathrm{Aiii}^{\mathrm{r}}$, Aiiv: "Denn es die tägliche erfahrung bezeugt/ wie mancherley wunderseltzame/ abenthewerliche/ spöttische unnd zum theil auch schmehliche judicia, gemelte Fraternitet außstehen muß/ bald wirdt sie von diesem/bald von jenem auff die bahn geritten."

184 Ibid., Bvr: "Ich bin drey und dreyssig Jahr alt/ und habe nun dreyzehen Jahr fast immer gereiset/ unnd seynd mir uber zween nit zu handen gestossen/ welche die rechte materiam gewust/ es mögen aber wol etliche mehr seyn die sie kennen/ ob wol zwar wenig der Welt davon bekant ist." Cf. ibid., Biiiv.

185 Ibid., Aiiiv: "Die zeit wirdt kommen/ daß vieler Herzen Gedancken offenbar werden/ zehen Jar passieren wol hin/ aber man hat alsbald den Rohl zu der zeit auffgeschüsselt/ qui non hodie est aptus, cras multo minus erit; qui non nunc, vix tunc: Bekanter möchte wol zu der zeit dieses Werck sein dann itzo/ aber nimmermehr wirdt ein offener Jahrmarck darauß werden/ es erwehnet in irem schreiben die fraternitet doch sehr finster/ was ire axiomata seyn/ laß dir die zeit nicht lang werden/ sey weiß/ verschwiegen/ und bestendig/ soltu es wissen es ist zeit genug thue du das deine dabey." 
himself from the scholars of the universities, but his criticism of the educational establishment did not emulate that of Haslmayr. Compared to Haslmayr, Julianus was much more explicit in his refutation of Aristotelianism and Aristotelian metaphysics; he had recourse to alchemy and not to Paracelsus when rebutting Aristotle; and, most importantly, he conceded that the deplorable state of the contemporary arts called out for a reform programme. Plato and Aristotle, he argued, would turn away in revulsion from the philosophies that later authors propagated in their names: "If Plato and Aristotle were to see the coinage of this age, I do not doubt that they would repudiate the incuse of its monks, and invoke with wonder the previous ages."186 But also Aristotle himself, Julianus argued, had not developed a sound philosophy because he had drawn upon an earlier one which he had not fully comprehended: "I would almost say that Aristotle himself had not understood [De meteoris] in the right way, because it looks as if he had received it from an old chemical library and copied it." 187 Aristotle's Meteorology IV, indeed, during the Renaissance was often seen as an alchemical work. ${ }^{188}$ Julianus regretted that Aristotle's views, which were less valid than the alchemical ideas that had come before him, were still prevalent at universities and communicated in the distorted version of monkish Scholasticism - but he took comfort from the belief that the difference between the old and the new sciences, the wrong direction previously taken and the new path of truth, was soon to become apparent:

Look at how the arts and sciences increase, contemplate each of the sciences, arts, faculties and disciplines, and you will soon find the difference between what is old and what is new, and not just in those arts that one calls liberal, but also in all other arts, such as in manual labour, in sum in everything that a human being may know. ${ }^{189}$

186 Ibid., Avr: "[...] wann Plato und Aristoteles denarium huius seculi sehen solten/ ich zweiffele nicht/ si würden das geprege ihrer münche verleugnen/ und mit verwunderung priora secula beschweren."

187 Ibid., Av ${ }^{\mathrm{r}}-A v^{\mathrm{v}:}$ : Ich wolte fast sagen/ das Aristoteles selbst gemelt Buch [De meteoris] nicht nach dem rechten grund verstanden/ dann es sich ansehen lest/ als habe ers auß einer alten Chymischen Bibliotheck bekommen/und außgeschrieben."

188 Newman, Atoms and Alchemy, ch. 3.

189 Julianus de Campis, Sendbrieff, Avir-Aviv: "Man sehe wie die Künste unnd Wissenschafften zunemen/ man betrachte nur die scientias, artes, facultates unnd disciplinas eine jeder insonderheit/ man wirdt den underscheid bald finden/ was alt oder was new sey/ unnd 
Julianus expected that the true liberal arts as well as all sciences and crafts would soon replace those still practised at universities. While Haslmayr had been concerned with the imminent end of the world, the anonymous replies had predominantly been concerned with the return of original wisdom, and Maier denied the possibility of a reformation, Julianus expected that all human intellectual activities would soon be transformed. Since Julianus and C.H.C. supported the reformation by the Rosicrucians only in a limited way, they extracted it from the original apocalyptic context and figures. The defeat of the pope as Antichrist, the expectation of a lion as political ruler, and the celestial portents announcing a new age, played no part in their reforming initiatives and were deemed irrelevant to the conclusion that current medicine and sciences were corrupt and needed reform. For this reason, their replies differ profoundly from Haslmayr's earlier pessimistic Answer, but present a novel attempt to improve arts and studies.

\subsection{Rosicrucian Theosophy and the Reform of Divine and Human Things}

\section{Know God}

In his Letter, Julianus provided a specific interpretation of the announced changes as he sought to explain the true intention and philosophy of the Rosicrucians. The old sciences were not only to be abandoned, they were to be replaced with a very different type of learning. When discussing the Rosicrucian philosophy, he took several elements, which were hinted at in the manifestos, and elaborated upon them, explaining that these were in fact the main objectives of the fraternity. The Rosicrucian message was thereby interpreted in a specific way and accordingly embedded into his own worldview.

One of the central elements in his Letter is the distinction between ergon and parergon. In the Fama there was once mention of a parergon, namely when the text describes the transformation of metals and the making of gold, which was said to be merely a parergon, a secondary activity. ${ }^{190}$ The first responder

nicht allein in diesen welche man freye nennet/ sondern auch in allen andern/als in Handarbeiten/ summa in allem was ein Mensch wissen mag."

190 Fama, 125-126: "So bezeugen wir hiermit öffentlich/ [...] daß ihnen Gold zumachen einen geriches und nur ein parergon ist/ derengleichen sie noch wol andere etlich tausend bessere stücklein haben. Und sagen mit unserm lieben Vatter/C.R.C. Pfuh aurum nisi quantum aurum, dann welchem die ganze Natur offen/ der frewt sich nicht daß er gold machen kan/ oder wie christus sagt/ ihme die Teuffel gehorsamb seyen [...]"; ibid., 124-125: 
to the Fama, Haslmayr, briefly referred to the practice of transmutation, and agreed that the making of gold was nothing but a parergon: "and you [brethren] however regard the making of gold to be just a parergon, and you have treasures which are a thousand times better, with which you cure all diseases out of the light of God and nature (like Paracelsus) and this without reimbursement."191 The Rosicrucians, according to Haslmayr, considered such "despicable goods" as gold to be nothing but "dung," and they used their treasures instead for medicinal purposes. ${ }^{192}$

Not surprisingly, Julianus also associated the parergon with praxis and alchemy, and for him it entailed the making of the philosophers' stone. This stone was sought after often not for the sake of wisdom, he believed, but for money. He denounced would-be Rosicrucians interested in becoming members only in order to produce the philosophers' stone; ${ }^{193}$ criticised alchemists that dismissed the Rosicrucians because the latter would think so little of the "high secret of tincture," that is, the art of transmutation; ${ }^{194}$ and rejected alchemists who claimed that if the Rosicrucians were not primarily involved

"Was aber sonderlich zu unser zeit/ das gottloß und verfluchte Goldmachen belangt/ so sehr überhand genommen/ daß zufordest vielen verlauffenen henckermässigen Leckern/ grosse Büberey hierunter zutreiben [...] als auch von bescheidenen Personen numehr dafür gehalten wird/ als ob die mutatio metallorum der höchste apex und fastigium in der Philosophia were [...]." See also above, p. 121.

191 Haslmayr, Antwort Aiiiir: "[...] unnd ihr aber das Goldmachen nur für ein Parergon achten/ unnd tausendt mal höhere Magnalia habt/ darmit ihr auch auß Gott unnd der Natur Liecht (wie Theophrastus) alle Kranckheiten umb sonsten curiert." Compare also: Fama, 106: "[k]einer solle sich keiner andern profession außthun, dann krancken zu curiren und diß alles umbsonst [...]."

192 Haslmayr, Antwort, Bv: "Dann ewre Gemüter geben es uns zuverstehn/ dieweil ihr mit Paulo die schnöden Güter (so wider die Lieb des Nechstens erobert in wucher) nur für ein Stercus achtet/ darnach alle Welt mit höchstem fleiß/ wohne unnd Arbeit Tag und Nacht trachtet/ und jetzt müssen sie darvon/ und ander besitzt es."

193 Julianus de Campis, Sendbrieff, Biir: "Im Außschreiben der Brüder vom Rosen Creutz wirdt gesatzt/ das Magisterium lapidis philosophici sey bey ihnen ein Parergon. Hieruber ergert sich mancher, unnd es sehen sich dreyerley Richter an. Der erste gedenckt/ harr ist das ein Parergon, oder den Rosen Creutzern ein gemein Beywerck/ so muß ich fleiß answenden/ das ich in die Brüderschafft auffgenommen werde/ das wirdt sehr gut für mich seyn/ Dann alsdann bin ich ein magnum virum, wann ich nur dieses Parergon erlange/ so frage ich nichts nach der anderen Wissenschafft. Aber dieser iudex fehlet weit."

194 Ibid., Biir-Biiv: "[...] Der ander felt auff einen unglauben/ und sagt/ Ich habe allezeit die Confection Magisterii Philosophici für die höchste Wissenschafft gehalten/ so jemals in der Welt mag seyn gefunden worden/ unnd die Rosen Creutzer achtens für ein Folgewerck/ welches ihrer scienz davon sie schreiben nur von fern nachfolget. Wolte derhalben schier glauben/ daß es nichts sey mit der Brüderschafft/ weil sie das hohe Geheimnuß der Tinctur so geringe achten. Dieser iudex ist auch auff unwegen." 
in alchemy, their true art must be devilish. ${ }^{195}$ Whereas Maier, G.A.D. and the anonymous author of the Preface to the Confessio had praised the Rosicrucians for their alchemy, Julianus considered it an offence against God to mistake the Rosicrucians for men involved in that vile transmutational art.

He did not, however, ban the study of the perishable natural world from sight. In the natural world one could study and investigate God's marvels. The parergon, alchemy, was not a means to obtain gold, but should be used to reach God and to acquire hidden wisdom. In this praxis, the human being "makes himself into an abstract and separate human being"; he "marvels at God, divine wisdom, and divine works" and "sees as in a mirror the future splendour of the other eternal life." 196 Through the study of the created world humans can learn about the eternal life of the New Jerusalem and acquire a preview of their eternal blissful future, which means that Julianus associated the parergon with apocalyptic alchemy, alchemy used to reveal divine secrets. ${ }^{197}$ This is why the reform of the sciences was so important to him, because through the right kind of natural investigations humans could learn about and approach divinitya claim suggesting that Julianus was also far from convinced by the orthodox Lutheran doctrines.

Particularly relevant in this special alchemical praxis was a physical entity that still needed to be investigated, and which, Julianus hoped, would be revealed by him in due time. According to him, humans must commit themselves to this true material substance. This matter was of a spiritual or ethereal nature rather than corporeal, "not gold but the seed of gold, or virgin gold." Julianus also characterised it as a vapour, mineral sulphur and mercury (often the ingredients of the philosophers' stone), premature gold (electrum), and "the root of all metals" - all descriptions that suggest that this "philosophical matter" was the philosophers' stone that could be used to transform bodies and

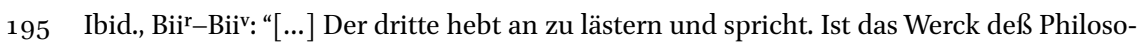
phischen Steins bey den Brüdern vom Rosen Creutz ein schlecht geringe nachwerck: So muß ihre rechte sciens und Wissenschafft/ welche für das Cardinal Werck bey ihnen gehalten wirdt/ eine lauter Teuffeley/Zauberey/ Abgötterey/ unnd verfluchtes wesen seyn/ der ich gehört habe/ daß keine höhere Wissenschafft in der Welt gefunden werde/ als de metallorum transmutatione."

196 Ibid., Biiir: “[...] unnd wann der Mensch also in spiritu descendirt ad praxin operis vniuersi, so felt er auffs Parergon, und macht sich wider zum abstracten und separaten Menschen/ der in steter bewegung der höchsten Weißheit würcklich versiret, er thut und gedenckt nichts/ als daß er sich uber Gott/ Göttlicher Weißheit und göttlichen Wercken/ verwundert/ und in dieser Arbeit/ sihet er gleichsam als in einem Spiegel die zukünfftige Herrligkeit/ deß andern ewigen Lebens [...]."

197 Cf. above, p. 121. 
metals. ${ }^{198}$ Julianus confessed: "I have known now for five years through God's mercy the right, true, sole, general matter about which the old philosophers have written, and have touched this with my hands just recently, and I have seen it with my bodily eyes." 199 The philosophers' stone was the means to making the purest gold and the key to perfecting this world. Through the study of this matter God could be observed and eternity could be viewed. Unfortunately, Julianus was unable to share any further details of this special matter or enlighten his readers through a more extended description of it, his reasons being the need for further investigation and the lack of other, trustworthy people with whom to work. ${ }^{200}$

More important still for Julianus was the ergon, the main task or work of the Rosicrucians. This term was neither mentioned in the manifestos nor discussed by Haslmayr, but Julianus thought that it was exactly this ergon that needed to be explained to understand the brethren's true intention and philosophy. This ergon, he thought, was nothing other than the study of the Supreme Being, the wisdom and knowledge of God: theosophy. With this idea, he moved from a material, alchemical praxis to an equally heterodox intellectual study of God.

The term "theosophy" was first coined by Porphyry (235-305), who suggested that theosophers were ideal beings: philosophers, artists, and priests in one. Throughout ancient and medieval times, the term was used by different philosophers in various ways. In historiography, diverse medieval theologians and mystics have been classified as belonging to this tradition, including the Christian monk Maximus the Confessor (58o-662) and the German theologians and

198 Julianus de Campis, Sendbrieff, Biiiiv-Bvv: "[...] wann du aber die rechte materiam kennetest/ und wüstest dieselbe ad gradus naturae per rotam artis zu tractiren, so kemestu zur Häuptstadt unnd zu dem allgemeinen Emporio, dem Gelehrten ist gnug geprediget, etc. Was ist dann unser materia die rechte warhaffte uhralte Philosophische materia? Darff ichs sagen? Doch ich sage dir es vernimb es recht: Nostra materia est Spiritus non corpus: nostra materia non est minerale, sed sulphur et Mercuriu[s] mineralis, unctuositas et vapor, electrum immaturum minerale, nostra materia non est aurum sed semen auri vel aurum virgineum: materia nostra non est metallum sed metallorum omnium radix." On the alchemical study of a spiritual entity, see: Zuber, "Spiritual Alchemy," 34-44, 62-63, 70 , passim.

199 Julianus de Campis, Sendbrieff, Bv-Bvir: "Ich [...] bekenne daß ich nun fünff Jahr durch Gottes Gnade die rechte/warhaffte/ einige/ allgemeine/ Materiam dauon die alten Philosophen geschrieben/gewust habe/ unnd habe dieselbe noch newlicher zeit mit meinen Händen betastet/ unnd mit meinen leiblichen Augen gesehen."

200 Ibid., Bvir: "Dann ich sag es klar herauß/ ich habe noch nie in unser materia gearbeit/ die ursach ist/ daß ich noch immer ferner nach forsche/ daran hat es aber am meisten gemangelt/ daß ich keinen angetroffen/ dem ichs noch zur zeit hette vertrawen können." 
mystics Meister Eckhart and Johannes Tauler. ${ }^{201}$ Also in the early seventeenth century, the notion enjoyed no consensus in terms of what it was taken to represent. It would therefore be impossible to formulate a common definition of "theosophy" beyond broad assertions that it concerned the study of divinity in one way or another and that it emphasised the relationship between God, nature, and human beings. ${ }^{202}$ Theosophy, in contrast to theology, also entailed the study of the world as a means to acquire knowledge of God, while at the same time it improved the knowledge of nature, as we have seen in the case of Julianus. ${ }^{203}$ In addition, theosophers often believed that humans could connect with the divine world with the help of their imagination.

A famous example of a seventeenth-century theosopher was Valentin Weigel, who drew on Paracelsian notions such as the microcosm-macrocosm analogy and believed that true knowledge could be acquired through introspection. ${ }^{204}$ Weigel understood human beings to contain within themselves the entire world, the macrocosm. In his Gnothiseauton, he explained how, by knowing the microcosm, humans could acquire knowledge of the macrocosm. ${ }^{205}$ Human beings should not be concerned with the external reality, but primarily with the inner Word. ${ }^{206}$ According to Weigel, there indeed existed a unity between humanity, nature, and God, ${ }^{207}$ and he underlined the importance of the transformation of the internal life and the reform of oneself. His works

201 Cf. Versluis, Theosophia, introduction.

202 On the lack of a unified definition and the common characteristics, see: Faivre, Theosophy, Imagination, Tradition, 1-8; idem, "Christian Theosophy," in Hanegraaff (ed.), Dictionary of Gnosis and Esotericism, 259. For a concise introduction to early modern theosophy, see: Gilly, "Khunrath und das Entstehen der frühneuzeitlichen Theosophie."

203 Gilly, "Khunrath und das Entstehen der frühneuzeithlichen Theosophie."

204 On Weigel, see: Peuckert, Pansophie, 290-310; Wehr, Valentin Weigel; Weeks, Valentin Weigel; Faivre, Theosophy, Imagination, Tradition, 50-59. Paracelsus' theories of medicine, alchemy, and correspondences, for example, as well as his notion of a spiritual body and his use of the microcosm-macrocosm analogy, influenced the thought of early modern theosophers; see: Faivre, Theosophy, Imagination, Tradition, 6, 10; idem, "Christian Theosophy," in Hanegraaff (ed.), Dictionary of Gnosis and Esotericism, 261. Gilly names Paracelsus, Heinrich Nollius, Robert Fludd, and Oswald Croll as theosophers; see: Gilly, "Khunrath und das Entstehen der frühneuzeithlichen Theosophie." Other theosophers include Heinrich Khunrath and Johann Arndt. On Khunrath, see: Forshaw, "Paradoxes, Absurdities, and Madness"; on Arndt, see: Koepp, Johann Arndt.

205 Weigel, $\Gamma N \hat{\Omega} \Theta I$ IEAYTóN, Nosce te ipsum. Erkenne dich selber O Mensch.

206 Here, Weigel is inspired by such spiritual Protestants as Sebastian Franck and Caspar Schwenckfeld; see: Williams, The Radical Reformation, 108-116, 255-258, 264-266; Faivre, Theosophy, Imagination, Tradition, 7, 51; McLaughin, "Spiritualism"; idem, "Radicals."

207 Versluis, Theosophia, 97. 
circulated from about 1610 onwards and might have had an influence on the theosophy of Julianus.

To be sure, there was no explicit mention of theosophy in the Fama and Confessio, but these manifestos did refer to the knowledge of both the Son and nature, and Julianus took the Rosicrucians to be students of divine wisdom. Unlike Weigel, he did not discuss the study of oneself, but he complemented the study and reformation of the outer world by a reformation of the inner world to be achieved through the knowledge of God. To this end, according to Julianus, the brethren were concerned with "the highest science of God, of the divine essence and will, of the divine miracle, of divine works, of heavenly prophecies, of apostolic genuine spirit."208 To study the will of God was certainly unorthodox, and was deemed impossible by both Luther and official Lutheran texts on the supposition that humans were incapable of acquiring complete knowledge of God, because He always remained hidden to them (Deus absconditus). ${ }^{209}$ According to Julianus, the Rosicrucians' central aim was to learn and reveal God's divine secrets through a "secret wonderwork and all hidden powers of the highest God." Their science was an "abstract, secret, and sublime work, and no Aristotelian metaphysics." 210 Julianus used both the practical investigation of the unnamed material and the higher study of theosophy to acquire insight into divinity. He took the brethren not first and foremost for physicians or alchemists but for theosophers who had substituted established learning with direct divine inspiration and with the study of that Being that was traditionally believed to be beyond human grasp.

In the study of the parergon, humans were separated from everything else and not affected or supported by anything or anyone. In the study of the ergon, in turn, they were united with the divinity:

When the highest, most wise and merciful God has made you and me to such an extent part of His spirit through the verdict of His secret

208 Julianus de Campis, Sendbrieff, Aviiv, Aiiiir ${ }^{r}$-Aiiiiv: "Niemand kümmer sich auch nicht/ daß die wissenschafft welche die Brüder bekennen unnd treiben/ ein superstitios oder Aberglaubisch Werck sey/ oder daß das Gewissen dadurch beschweret werde/ solches geschihet keines weges. Wie kan die höchste Wissenschafft von Gott/ Göttlichen Wesen und Willen/ Göttliches wunders/ Göttlicher Wercke/ himlischer propheceyhung/ Apostolisches warhafftiges Geistes/ durch Vatter/ durch Sohn/ und durch den Mittelband, per Spiritum agitantem caelestem, ein abergläubisches ding seyn?"

209 On this, see further below, pp. 323-324.

210 Julianus de Campis, Sendbrieff, Biiv -Biiir: "Es ist ein abstract, secret, unnd sublim Werck/ unnd keine Aristotelische Metaphysica, [...] das belanget deß höchsten Gottes geheime Wunderwerck/ unnd all verborgene Krafft [...]." 
and immutable council, for which I beg patiently daily, then one may do without the world, and leave out all transient favour and splendour $[\ldots]{ }^{211}$

God could grant humans access to His spirit so that they could leave the perishable world behind. The world was to be studied and transformed, but only in order to extricate oneself, to become free from it. One's aim was ultimately the return to God, one's origin. Julianus believed the Rosicrucian manifestos to have reintroduced theosophy and to have heralded such a union of the human with the divine. This idea of a union with God was indeed reminiscent of the claim, briefly touched upon in the manifestos, that religion was internal and that the microcosm mirrored God, heaven, and earth of the macrocosm. ${ }^{212}$

This notion of a union with God may have been inspired by Weigel, who in his On the Place of the World (1576) maintained that God could be found within human beings: "Hence no external place, not even our mortal body, is our true dwelling, but rather God within us, and we in God. Whoever lives in God and God in him is at home in his fatherland and cannot be driven out, no matter in what place in the world he will be." ${ }^{213}$ Elsewhere he explained:

O my creator and God, through Thy light I know how wonderful I am created: Out of the world am I created, and I am in the world, and the world is in me. I am also created out of You, and remain in You and You in me $[\ldots]$. And all that is in the greater world is also spiritually in me; thus am I and it one. ${ }^{214}$

According to Weigel, humans as microcosms represented and encompassed both the world and God. The kingdom of God was within humans, but they could also unite with Him. ${ }^{215}$ Likewise, Haslmayr wrote in a later work that not only the external world but Christ himself could be found within man. Like the

211 Ibid., Biiir: "Wann der allerhöchste/ allerweiseste gnädige Gott dich unnd mich/ durch die sentenz seines geheimen/ unnd unwandelbaren raths/ so weit seines Geistes theilhafftig gemacht/ warumb ich in gedult täglich flehe/ so kan man der Welt wol entperen/ und vergenglich gunst und herrligkeit bleiben lassen [...]." On a union with God as spiritual alchemy, see: Zuber, "Spiritual Alchemy," 38-39.

212 See above, p. 145.

213 Weigel, Ein nützliches Tractätlein vom Ort der Welt; On the Place of the World, edited and translated in: Weeks, Valentin Weigel: Selected Spiritual Writings, 102. See also ibid., 138.

214 Weigel, quoted and translated in Versluis, Theosophia, 96, cited from: Wentzlaff-Eggebert, Deutsche Mystik Zwischen Mittelalter und Neuzeit, 177-178.

215 Weeks, Valentin Weigel, 8o. 
Protestant Spiritualists of the previous century, and akin to Weigel, he argued that "Christ can only be found in His temple, in which He is the altar, which temple is the human heart."216 He explained that "the word of God, Fiat, lives in all creatures, as a soul and a power."217 Because God was to be found within us, according to the view of the Protestant Spiritualists and Weigel, we should not have walled churches, but instead honour the Church within.218

Similarly, Julianus hoped to be able to leave the world behind through achieving a union with God, and presumably to live in spirit as if in the eternal world, a world that could already be studied in the parergon. This is why, according to Julianus, one should first study the ergon and only thereafter the parergon: "Search first the realm of God, that is the wisdom about God, that should be your ergon. In this way all else will befall you, that is what depends on the wisdom of God and what is verified in human beings and their works. That is your parergon." ${ }^{219}$ The study of the human world was secondary to the study of the divine, both in order and in quality, but ultimately they had similar objectives.

Comparable views were expressed by the aforementioned respondent to the manifestos, I.B.P. He argued that knowledge of God could, on the one hand, be acquired through prophecies and from Scripture. ${ }^{220}$ On the other hand, according to an unorthodox notion, humans could gain knowledge of Him through internal study, more specifically through a union with God: "it consists of faith through which the soul of the microcosm or human being will be united with Christ as the true God." Such faith he called an "infused science"

216 Haslmayr, Astronomia Olympi Novi, 38: "Dann Christus ist nur in seinem Tempel zu finden/ in welchem er der Altar ist/ welcher Tempel das Menschlichen herz ist."

217 Idem, Theologia cabalistica, 45: “[...] das Wort Gottes, Fiat, in allen geschöpffen wohnendt/ als ein Seel unnd Krafft [...]." For Paracelsus on the new birth, see: Daniel, "Paracelsus on Baptism and the Acquiring of the Eternal Body"; idem, "Paracelsus' Astronomia Magna"; see also the preface by Toxites to his edition of Paracelsus' Astronomia Magna, mentioned in Chapter 2.

218 Faivre, Theosophy, Imagination, Tradition, 51. August von Anhalt was also of this view; see: Gilly, Adam Haslmayr, 124-125.

219 Julianus de Campis, Sendbrieff, Biiiv: "Suchet am ersten das Reich GOttes/ id est sapientiam de Deo, Das laß dein ergon seyn. So wirdt euch das ander alles: id est quae à sapientia Dei dependent \& in hominibus eorundemque operibus verificantur; zufallen/etc. Das ist dein Parergon."

220 I.B.P., Sendschreiben, 104: "Nun wird Gott von dem Microcosmo auff zweyerley weise erkandt/ nemlich Eusserlich und Innerlich/ die eusserlich Erkandnuß wird zu wege gebracht/ durch eusserliche Organa und Mittel/ als die vornemblich seyn/ die Schrifften Göttliches Worts/auß eyngeben deß heiligen Geistes/ durch die Patriarchen/ Propheten und Apostel beschrieben und der ganzen Welt fürgestellet." 
(scientia infusa), or rather "an angelic and prophetic science" through which God cannot be "understood" but "captured."221 This infused science could unite mortal human beings to Christ and the immortal divinity. Only through such a union could one completely acquire divine wisdom. Like Julianus, Weigel, and Haslmayr, I.B.P. argued that this would take place within human beings, because "the microcosm is the temple of God and of the holy Trinity, and also a dwelling place of the Holy Spirit."222 Humans have the trinitarian God within them, and could become enlightened by acknowledging God within. Not the world but man's internal being was the object and place of study.

I.B.P. believed the Rosicrucians to be experienced in such a union with God, and he claimed that they had studied under the Holy Spirit. The Holy Spirit was seated within humans in an internal school named the "schola mentalis." Besides this "schola mentalis," I.B.P. recognised an internal "schola rationalis et discursiva" and a "sensualis schola," upon which he did not comment any further. ${ }^{23}$ The Holy Spirit was the teacher at those internal schools, teaching His pupils, notably the Patriarchs, prophets, and apostles, from within.224 At the internal schools, these venerable figures had learned about all secret mysteries of God and of the world, through direct inspiration from the Holy Spirit. While these three schools reflected a traditional Christian understanding of the three parts of human beings (spirit, rationality or soul, and body), they were also reminiscent of Weigel's description of three ways of knowledge, which were the supreme, intellectual, and sensory ways—each similar to I.B.P.'s internal schools as internal ways of knowledge. In The Golden Grasp (1578),

221 Ibid., 105: "Gleich wie aber nicht allein eusserlich/ sondern auch innerlich im Herzen unnd gemüth deß Microcosmi als in dem Centro deß ewigen Horizontis, unnd dasselbe zwar durch den glauben an Christum/ Gott der HErr in seiner unendlichen Ewigkeit/ ob wol nicht begriffen/ doch etlicher massen gefasset wird/ welches denn ein scientia infusa oder vielmehr ein Englische unnd Prophetische Wissenschafft genandt wird/ und bestehet im Glauben/ dadurch die Seele deß Microcosmi oder Menschens mit Christo als dem wahren GOtt vereyniget wird."

222 Ibid., 106: "[...] denn der Geist Gottes erhelt die Fücklein der Erkändtnuß in dem Microcosmo, die offt ein grosses Fewer der Göttlichen Weißheit unnd Liebe anrichten/ welches kein Wunder/ weil der Microcosmus ein Tempel Gottes und der heiligen Dreyfaltigkeit/ und also auch ein Wohnung deß heiligen Geistes ist."

223 Ibid., 106.

224 Ibid., 106: “[Die heiliger Geist ist] allein deß Lehrmeisters/ wie die Seele deß Menschen eines Schülers Ampt verwaltet. Da denn die Schola mentalis ihre statt hat/ in welcher die Patriarchen/ Propheten/ und Apostel gelehret und unterwiesen worden/ welche auch/ wie auß dem Exempel deß Apostels Pauli zusehen/ biß in den dritten Himmel verzucket worden seynd." Cf. 2 Corinthians 12:2-4. 
Weigel explained that humans could gain knowledge via their mind, reason or sensory organs, and their imagination. ${ }^{225}$

The fraternity, according to I.B.P., had its origin in these internal schools, which he claimed had been attended by Christian Rosencreutz, according to his interpretation of a description given in the Chemical Wedding. ${ }^{226}$ Because of their privileged position, namely as co-students of the Patriarchs, prophets, and apostles, the Rosicrucian brethren could reproduce the evangelical wisdom after the example of Christ, which made them highly important Christian prophets educated in supernatural matters. ${ }^{227}$

Both Julianus and I.B.P. drew on an upcoming alternative to the prevailing but failing practice at universities, namely theosophy, when the study of this world would to a large extent be substituted by the study of eternity. I.B.P. and Julianus held views similar to those of Johann Arndt, who criticised university teaching and encouraged readers to study nature, but who also acknowledged God within and aspired towards the divine reality. ${ }^{228}$ These responses to the manifestos, much like the Rosicrucian manifestos themselves, were unorthodox and antithetical to the establishment because the notion of complete knowledge of the world and divinity before the end was in opposition to confessional dogmas. Where I.B.P. and Julianus differed from most anonymous responses was in the methods they prescribed for acquiring complete knowledge. Whereas most of the anonymous letters argued that perfect wisdom could be acquired by receiving a perennial philosophy, and whereas C.H.C. and Julianus further wanted to reform the arts and sciences, Julianus and I.B.P. also made explicit claims about the need to unite with the divine.

225 See especially: Weigel, Der güldene Griff, ch. 8.

226 I.B.P., Sendschreiben, 107: "Auß diesen dreyerley Schulen Göttlicher Erleuchtung/ saget ihr recht und wol/ daß ewer Vatter unnd glückseliger erster Stiffter ewer Fraternitet/ Fr. C.R. zu der Hochzeit Göttlicher Weißheit/ nach vieler Mühe/ Arbeit unnd Gefahr kommen sey/ wie denn auch/ das eben auß diesem Fundament ewer Fraternitet iren Anfang genommen unnd zu glücklichem Auffgang kommen/ man auß ewrem Schreiben mit grosser Lust zuvernehmen hat."

227 Ibid., 107-108: “[...] inmassen auch der Heyland aller Welt/ ob er wol allein alles gekundt hat/ dennoch nicht zulassen wollen/ daß die Evangelische Warheit duch ihn allein fortgepflantzet würde/ sondern er hat sich hierzu deß getrewen Dienstes seiner lieben Apostel auch brauchen wollen/ nach welchem Exempel denn auch ewer Brüderschafft recht und wol angestellt worden."

228 On Arndt and Andreae, see above, section 3.3. 


\section{Know Thyself}

The study of theosophy was an even more central theme in the response of Daniel Mögling (1596-1635) ${ }^{229}$ Mögling's defences of the Rosicrucians against attacks by others were issued under the pseudonyms Theophilus Schweighart and Florentinus de Valentia, as had already been noted by Widemann: "Florentinus de Valentia, also named Daniel Mögling, doctor of medicine, who also calls himself Theophilus Schweigkartt Constantiens. Well-intentioned."230 $\mathrm{He}$ came from a family of Tübingen scholars, and both Mögling's grandfather (Daniel Mögling, 1546-1603) and his father (Johann Rudolf, 1570-1596) had been professors of medicine at its university. ${ }^{231} \mathrm{He}$ himself also moved in the academic circles of Tübingen. He was acquainted with Andreae and Besold. Andreae was a distant relative of Mögling through his cousin, who had married Mögling's uncle in 16og. Andreae also referred to Mögling as someone who had visited him between 1614 and 1620. Mögling praised Besold in one of his texts (1619) and in a letter to Wilhelm Schickard dated 1627. He further corresponded with Kepler and was a close friend of Johannes Faulhaber (158o-1635), a mathematician and engineer who was later to be investigated for his Rosicrucian sympathies. ${ }^{232}$

Mögling wrote his Pandora of the Sixth Age (1617) under the pseudonym Theophilus Schweighart. To this text he added a riddle revealing his true name, which was soon solved by Besold. ${ }^{233}$ The following year, in 1618, he published

229 On Mögling, see: Schick, Das ältere Rosenkreuzertum, 184-188; Peuckert, Das Rosenkreutz, 123-124, 139-140, 152-155, 159-16o, 164; Van Dülmen, "Daniel Mögling”; Neumann, "Olim, da die Rosen Creutzerey noch florirt." Neumann corrected some biographical claims made by Van Dülmen; see: Neumann, "Olim, da die Rosen Creutzerey noch florirt," 99-100.

230 Widemann, Sylva scientiarum, 723: "Florentinus de Valentia, sonsten Daniel Mögling genanndt, Medicinae Doctor, der sich auch nenndt Theophilum Schweigkartt Constantiensem. Wohlmainenndtt," cited in: Gilly, Johann Valentin Andreae, 51. Gottfried Arnold once claimed that the pseudonym Florentinus de Valentia was Andreae's: Arnold, Unpartheyische Kirchen- und Ketzer-Historie, 1126.

231 Neumann, "Olim, da die Rosen Creutzerey noch florirt," 94-95.

232 Andreae, Vita, 9, 81; Neumann, "'Olim, da die Rosen Creutzerey noch florirt," 99-100. When authors supporting the Rosicrucian case became associated with the ideas of Johann Arndt and Valentin Weigel, Mögling and Faulhaber became more circumspect. This prompted Mögling to stop writing Rosicrucian tracts, while Faulhaber continued his public support for the Rosicrucians and was thereupon investigated by the University of Tübingen; see: Van Dülmen, "Daniel Mögling," 44-46. For the reports by the University on Faulhaber, see UAT, 12/18, nrs. 59a-u. See also the comments on Mögling in: Gilly, "Khunrath und das Entstehen der frühneuzeitlichen Theosophie," which argues that Mögling was influenced by Heinrich Khunrath. On Faulhaber, see: Schneider, Johannes Faulhaber.

233 Gilly, Johann Valentin Andreae, 94. 
his Wise Rosicrucian Mirror under the same pseudonym. ${ }^{234}$ In both texts, Mögling took it upon himself to correct "falsely conceived persuasions" of those he believed had understood nothing of the true intentions of the Fama and Confessio - persuasions he claimed had previously been rebutted by Julianus. ${ }^{235}$ For Mögling, the manifestos were expressions of theosophical wisdom.

Important here is the fact that, like Julianus, Mögling discussed the brethren's parergon and ergon, although his own explanation was much more elaborate than that of Julianus. He denied any interest in gold, reminding his readers of the phrase uttered in the Fama that "together with father Rosencreutz we say: pfuh, gold is nothing but gold." ${ }^{236}$ According to him, during the Last Days those who are taken by chrysopoeia will not be illuminated by God's light. Many readers, he argued, had been chrysophili, lovers of gold, rather than Christophili, lovers of Christ, and so he urged his readers to renounce the former and dedicate themselves to the latter. ${ }^{237}$ Alchemy could still be practiced, but this art was just a very minor part of the parergon, and readers should above all focus on the knowledge of themselves. ${ }^{238}$

Mögling believed that the true Rosicrucian objective was not to be found in wealth but in knowledge. The second chapter of the Pandora was entitled

234 The page numbers of the Speculum have been confused, although the text flows correctly. The order runs: $1-5,7,6,8-17,13,18,20,12$, so some numbers appear twice. When discussing the Speculum, the references will follow the page numbers as they appear on the folios, and will make explicit which of the doubled numbers is referenced.

235 Mögling [Theophilus Schweighart], Pandora, 3-4: "Was ich hierinnen gethan/ ist nicht geschehen euers von Gott genugsam illuminierten Fraternitet, einiges vorzuschreiben/ oder deroselben Hochweisen Judicio mich zuwidersetzen: Sondern einig und allein/ offtermelten Mydas sinnigen herzen ihre falsch concipierte persuasion zubenemmen [...], denen doch von Juliano de Campis verloffner zeiten genugsam solte respondiert seyn. Und hat mich hierzu noch mehrers bewegt [...] der general Weißheit zu adumbriren.” Mögling's references to Julianus and the similarities between the two may further suggest that Julianus was indeed a Tübingen scholar.

236 Ibid., 12-13: “[...] unnd dörffen wir kecklich sagen cum Patre Rosencreutzer/ pfuy, aurum nisi quantum aurum, verstehst du das und practicirest es recht/ wird dir an weißheit nicht mangeln." Cf. Fama, 125-126: "So bezeugen wir hiermit öffentlich daß solches falsch und es mit den wahren Philosophis ein geringes und nur ein parergon ist [...], Und sagen mit unserm lieben Vatter C.R.C. Pfuh aurum, nisi quantum aurum." See further above, p. 121.

237 Mögling [Theophilus Schweighart], Speculum, 8: "dann es heist: venite digni: Tu autem indignus Christophilus esse debes, sed Chrysophilus es [...]. Folge mir/ imitier die Vögel/ so in meiner Figur/ in freyem Lufft fliegen/ thue gemach/ Non est periculum in mora, maius in festinatione."

238 Mögling [Theophilus Schweighart], Pandora, 11-13. 


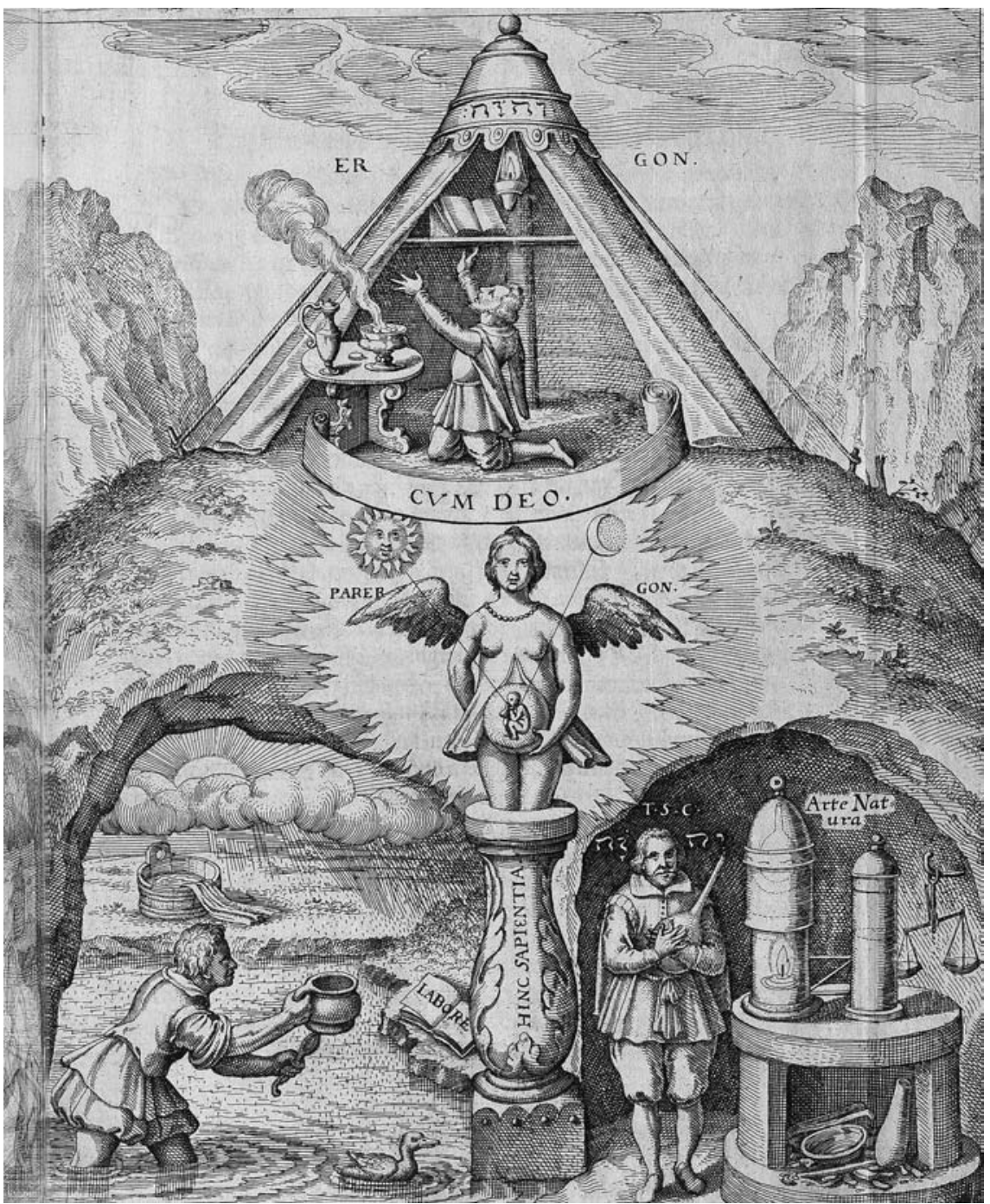

FIGURE 11 Daniel Mögling, Speculum Sophicum-Rhodostauroticum, fig. 2, HAB Wolfenbüttel

"On the knowledge of oneself," and it discussed the parergon. ${ }^{239}$ Time and again, Mögling advised his readers to "go into themselves," to study themselves and to learn everything from themselves. Whereas after Paracelsus, many scholars had turned from paper books to the Book of Nature, Mögling did not want to learn from either type of book but instead desired to acquire knowledge

239 Ibid., 11: "Das Ander Capitel. Von der erkanntnuß seiner selber." 
through internal investigations. By doing so, humans would learn everything about themselves and the world, because the greater world, including all sciences and faculties, lay within them. According to Mögling, the key to such knowledge lay in the conviction that humans were made not after the image of the macrocosm but after that of the microcosm: "Go into yourself, contemplate your entire fabric and overly-artistic structure, which the Heavenly Father has granted to you by making you in the image of the microcosm." ${ }^{240}$ According to the Fama, when the body of Christian Rosencreutz was discovered in his vault, he held in his hands a book that was written in gold and called "T."241 This book was amongst the Rosicrucians' highest treasures, and it explained that Christian Rosencreutz had created, as the text reads, "a minute world," a compendium, which was aligned with the macrocosm. ${ }^{242}$ To Mögling, humans were made in the image of just such a minute world. By studying themselves, they could learn the arts and the entire philosophy of the Rosicrucians:

Go into yourself [...], examine each and every thing, compare it with the great world, so that a sphere or globe follows from it, which centre is truth and in which all faculties accord. Then you will learn from this plenty of wonderful arts and crafts, you will understand the Rotae of the brethren, and the minute world, you will know how to assemble the general axioms and to cure all diseases as much as possible. ${ }^{243}$

The Rotae and Axiomata were again not discussed any further, but Mögling evidently took the Rotae to be the keys that explained the minute world and revealed the entire structure of the world. The Axiomata may simply have been general underlying truths that defined the patterns and correspondences

240 Ibid., 11: "Gehe in dich selbst/ betracht deine ganze fabricam und überkünstliche structur, so der Himmlische Vatter an dir erwisen/ in dem er dich nach dem ebenbildt Microcosmi formirt $[\ldots] . "$

$241 \quad$ Fama, 117-118.

242 Ibid., 118-119: “[...] posteritati eruendum costudivisset, \& jam suarum artium, ut \& nominis, fidos ac conjunctissimos haeredes, instituisset, mundum minutum, omnibus motibus magno illi respondentem fabricasset, hocque tandem praeteritarum praesentium \& futurarum rerum compendio extracto, centenario major, non morbo [...] ullo pellente, sed Spiritu Dei evocante illuminatam animam [...]."

243 Mögling [Theophilus Schweighart], Pandora, 11-12: "Gehe in dich selbst [...] examiniert alles und jedes/ conferiren es mit der grossen Welt/ das ein Sphaera und Globus darauß werde/ dessen Centrum veritas, darin alle facultates übereintreffen/ so wirstu hierauß lernen wunderlicher Künst und handgriff genug/ du wirst verstehen die rotas fratrum, und Mundum minutum, du wirst wissen axiomata generalia zu colligieren/ alle Kranckheiten/ so vil müglich zu heilen." 
between the microcosm and macrocosm from which also all medical knowledge followed. Mögling perhaps drew on Weigel's The Golden Grasp, which reads that

the human being $[\ldots]$ encompasses within him all creatures with the entire world. For that reason he is called the microcosm, that is, the minute world, and how he is created from it, in accordance with his mortal part, so he is placed amidst of it, and he is a centre, that is, a midpoint of all creatures. ${ }^{244}$

Mögling expected a readership of physicians, after the example of the Rosicrucians. By studying themselves in comparison with the greater world they could learn how to cure diseases, sometimes even through an inconspicuous herb that was collected "in keeping with the due time of the Rotae, in consonance with the microcosm and macrocosm. ${ }^{245}$ Here the Rotae have a temporal meaning; they turn in time into various constellations. According to Mögling, there existed a pre-established structure of sympathies and similarities in the universe, which exchanged forces according to the right temporal and spatial alignments. This view, too, echoes notions contained in the Fama, because the Rosicrucians' compendium was said to contain things of the past, present, and future. ${ }^{246}$ For Mögling, the Rosicrucian philosophy was encompassed in such a compendium, which could teach everything. Mögling's Rotae partly resembled the Rotae of Lull, which wheels spatially represented the entire universe, but were also the Rosicrucian wheels of time's keeping.

244 Weigel, Der Güldene Griff, Biiiv: "aus diesem eussernt Garten ist der Mensch geschaffen/ vnd begreifft in jhme alle Geschöpff mit der gantzen Welt, darumb er auch Microcosmos genennet wird/ das ist/ die kleine Welt/ und wie er daraus geschaffen ist/ nach seinem zeitlichen sterblichen Theil/also ist er in Mitten hinein gesetzt/ und ist ein Centrum/ das ist/ ein Mittelpunct aller Creaturen."

245 Mögling [Theophilus Schweighart], Pandora, 12: “[...] alle Kranckheiten/ so vil müglich zu heilen/ nit mit grossem unkosten/ nicht mit Edelgestein/ Gelt und Gut/ sondern manchmal mehr mit einem geringen in virtutum, summo gradu debito rotarum tempore cum Macro- \& Microcosmo consonante colligiertem Kräutlein außrichten/ als andere Doctores mit vil tausend Donnen Golts schweren recepten."

246 Fama, 118-119: "[...] posteritati eruendum costudivisset, \& jam suarum artium, ut \& nominis, fidos ac conjunctissimos haeredes, instituisset, mundum minutum, omnibus motibus magno illi respondentem fabricasset, hocque tandem praeteritarum praesentium \& futurarum rerum compendio extracto, centenario major, non morbo [...] ullo pellente, sed Spiritu Dei evocante illuminatam animam [...]." 
The call for a study of oneself had already been expressed in Weigelian and pseudo-Weigelian works. ${ }^{247}$ In his On the Place of the World, Weigel informed his reader that "if you can go into yourself, you will come to God in your fatherland."248 In The Golden Grasp, he had argued that "the assiduous contemplation of the works of God and the knowledge of oneself leads to God and makes the eye clear and bright; it also testifies that the understanding or knowledge flows from within outward."249 Haslmayr, who read Weigelian texts and may have published them at the secret printing press of August von Anhalt, had likewise emphasised in multiple writings the Greek exhortation $\gamma \nu \omega \theta_{l}$

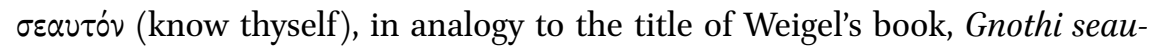
ton. $^{250}$ He explained that the knowledge of creation was accessible through self-knowledge:

For the highest wisdom is the wisdom of oneself,251 also in imitation of Cabalistic theology, magical astronomy, spagyrian natural philosophy, medicine, and mathematics, upon a free fundament, without the pagan philosophy, by which we should not be seduced. ${ }^{252}$

Such an interpretation of human beings resembled the Rosicrucian description of the microcosm-macrocosm analogy, of which the Fama said that human

247 For the study of oneself in pseudo-Weigelian writings, see: Zuber, "Spiritual alchemy," 56 74 .

248 Weigel, On the Place of the World, edited and translated in:Weeks, Valentin Weigel: Selected Spiritual Writings, 142.

249 Weigel, Der Güldene Griff, Br: "Die fleisige Betrachtung der Wercken Gottes und Erkantniß seiner selbst/ führet zu Gott vnd machet das Aug klar und hell/ bezeuget auch daß der Verstandt oder die Erkäntniß von jnnen heraus fliesse." Cf. also: Weeks, Valentin Weigel: Selected Spiritual Writings, 152-153.

250 Besides in Haslmayr's Answer, this Greek terminology was mentioned in his Apologia, $\left(\mathrm{HAB}, 163^{\mathrm{r}}\right.$ ); his Beschreibung des erschrecklichen Lebens (Niedersächsisches Staatsarchiv Wolfenbüttel, $23^{\mathrm{r}}$ ); his Theologia cabalistica which was published under Paracelsus' name in the Philosophia Mystica $(1618,44)$; and in his Pansophia (in Widemann's Sylva scientiarum, Hannover, 708).

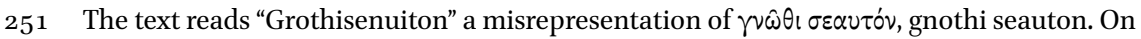
this, see also: Gilly, Adam Haslmayr, 81.

252 Haslmayr, Antwort, Aiiir-Aiiiv: "Die höchste weißheit nemblich das Grothisenuithon, auch nach der Cabalistischen Theologei, unnd Magischen Astronomei, unnd Spagyrischen Phisica, Medicina, unnd Mathematica, auß freyen fundament, ohn der Heyden Philosophei, von welcher wir nicht sollen verführt werden." Compare also Haslmayr's Astronomia olympi novi, 35: "Dann selig und uberselig mögen die Menschen/ die Länder/ die Stätte seyn/ welche die Gnad haben/ diesen Himmel das ist/Christum Jesum/ die ewige Weisheit/ und sich selbsten zu erkennen." 
beings contained within themselves "religion, politics, health, bodily parts, nature, speech, words and works [...]," which it described by a musical ana$\log .253$

Mögling complemented this parergon, the knowledge of oneself, with the ergon, which entailed the study of God. He did not discuss this ergon at any length in the Pandora, but the first chapter of this first text was titled "Theosophy." God, he clarified, could be found in everyone, as "God is all in all, and will yet be enclosed by nothing. He is the infinite circumference, whose centre is everywhere and His surface nowhere." ${ }^{254}$ A similar notion had earlier been expressed by the German theologian and philosopher Nicholas of Cusa (Nicolaus Cusanus, 1401-1464), who, in his On the Game of the Globe (ca. 1462), described by mathematical analogy that not God but Christ, like a point or atom, resided in the centre of a globe while also extending outwards, encircling and pervading all. ${ }^{255}$ This notion had later been taken up by Giordano Bruno in his Cause, Principle and Unity (1584), which explicitly referred to Nicholas of Cusa and illustrated this notion in a geometrical woodcut engraving. Bruno explained, also drawing upon the work of Ficino, that the soul was all in all. 256 Mögling's notion of precisely God as being the centre and circumference of everything had notably been described by Weigel, who in his On the Place of the World argued that "God is not only a centre but a circle of all creatures, that is, God and His will or Word is not only in all creatures but also outside of them, conceiving and encompassing them."257

In relation to such notions, Mögling, like Julianus, advocated the theosophical principle of a mystical union with God through Christ:

First you should know God, unite yourself thoroughly with Him through His Son Christ in the power of the Holy Spirit, direct all your willing and working after His pleasure, in sum change yourself entirely and put your

253 Fama, 97-98: "[G]leich wie in jedem Kernen ist ein gutter gantzer Baum oder Frucht, also die gantze grosse Welt in einem kleinen Menschen were, dessen Religion, Policey, Gesundheit, Glieder, Natur, Spraache, Worte und Wercke, aller in gleichem tono und Melodey mit Gott, Himmel und Erden ginge."

254 Mögling [Theophilus Schweighart], Pandora, 9-10: "Gott ist alles in allem/ und wird doch von keinem beschlossen/ er ist die unendliche circumferentz/ cuius centrum ubique superficies nullibi."

255 Nicholas of Cusa, De ludo globi, 56-58. Cf. Lüthy, "Centre, Circle, Circumference," 318.

256 Lüthy, "Centre, Circle, Circumference," 316, 318-319.

257 Weigel, On the Place of the World, edited and translated in:Weeks, Valentin Weigel: Selected Spiritual Writings, 135. Cf. above, n. 244. 
wealth in the last place. In this way, you will become healthy in your soul, and you are a theosopher. ${ }^{258}$

Theosophy was clearly not only the study of God, but included the necessary practice of uniting with Him. For Mögling, it therefore required an inner reformation.

In his second text, the Mirror, Mögling also suggested that his readers study the internal man, but no longer as some sort of higher-level parergon, but as one aspect of the ergon. Humans should perfect their soul while also listening to God's command, just as he believed the Rosicrucians did. ${ }^{259}$ This renders the transformation of oneself a moral obligation, namely to prepare oneself for a union with the divine. His emphasis on an individual reformation was directly related to his human genealogy, as he believed that humans originated from God:

But note, that everything that you have so far seen and contemplated on, finally comes together within you as in a centre and image of God (because all comes from one, and all goes to one). From there arises the same 'Know thyself', I say 'know thyself', that is how you come to pansophical perfection..$^{260}$

The parallels with Weigel are evident. Man was the image of God because he had come from God, and pansophical wisdom implied the perfect knowledge

$25^{8}$ Mögling [Theophilus Schweighart], Pandora, 10-11: "Erstlich must du Gott erkennen/ dich demselbigen durchauß vereinigen durch seinen Sohn christum in krafft deß H. Geistes/ all deinen willen und werck nach seinem wolgefallen anrichten/ Summa dich ganz verendern/ und deine vermöglichkeit hindan setzen. Auff dise weiß wirstu gesundt an der Seelen/ und bist ein Theosophus."

259 Idem, Speculum, 18: “[...] das beste aber is diese der Seelen Perfection/ welche geschicht/ so man den innerlichen Menschen recht erkent/ seine Sünd und unvermögligkeit betracht/ Gottes Gewalt und Barmherzigkeit zu gemüht fürt/ alle Menschliche Gedancken hindangesetzt/ ihme allein alles befihlt/ seinem willen gehorcht/ seinem Namen heyliget/ bitt/ lobt/ anrufft/ und glorificiert ohn underlaß. Dieses ist das Ergon, das Vorwerck/ die gröste und fürnembste Kunst/ und Wissenschafft so wol der Brüder deß RosenCreuzes/ als auch aller Christliebenden Menschen."

26o Ibid., 13 (2): "doch mercke/ daß alles/ was du bißher gesehen unnd contempliert/ kompt entlich in dir selber als in einem centro und Ebenbildt Gottes zusamen (nam omnia ab vno, omnia ad vnum) daher dann entspringt dasselbige Nosce te ipsum, Nosce teipsum inquam, so kompstu zur Pansophischen Perfection." 


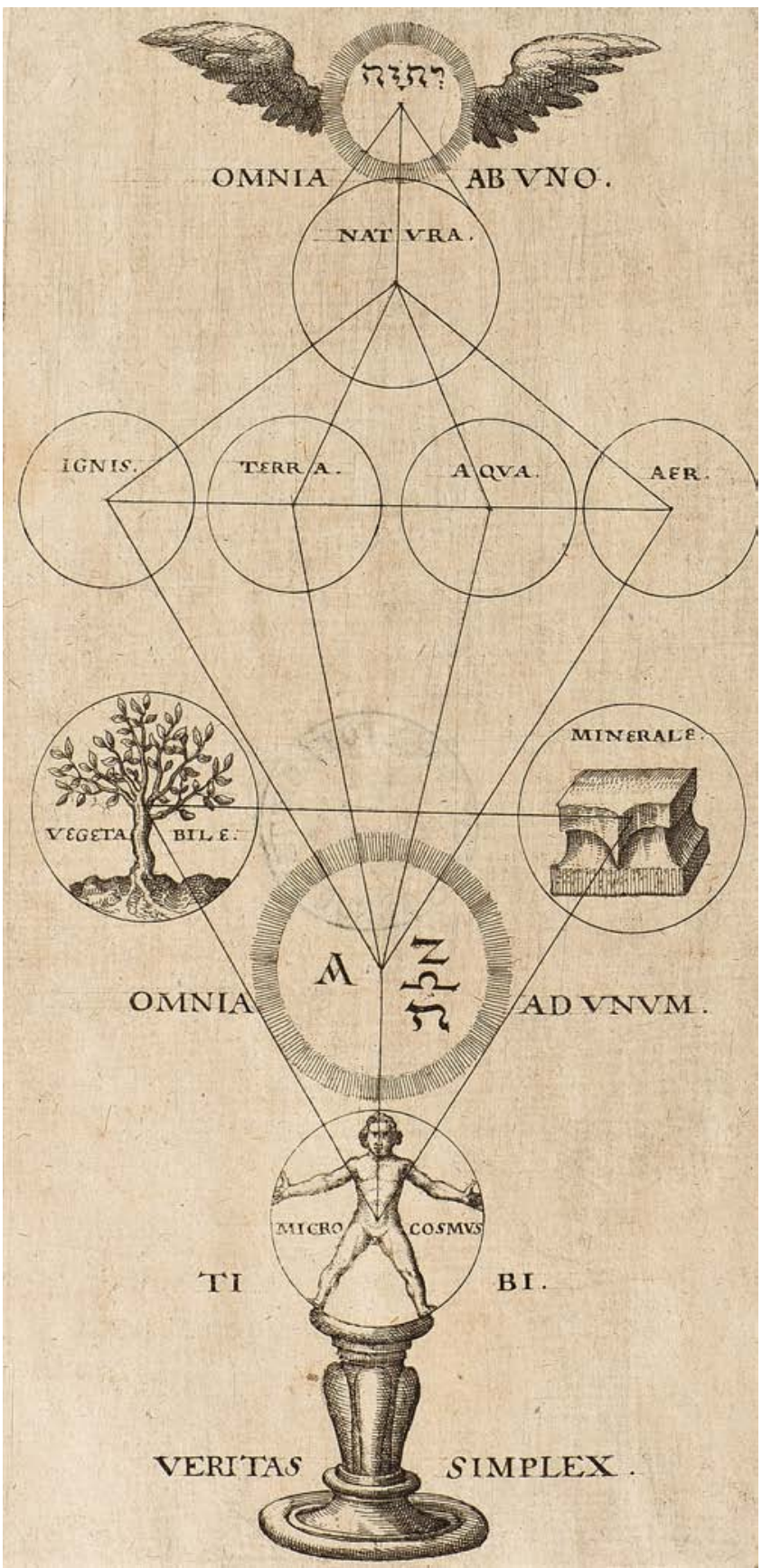

FIGURE 12 Daniel Mögling, Speculum Sophicum-Rhodostauroticum, fig. 3, НАB Wolfenbüttel 
of oneself in the awareness of one's origin and end. ${ }^{261}$ The term "pansophy" was not an uncommon term even prior to the most famous pansophist, Jan Amos Comenius (1592-1670), as it had been used by, among others, Heinrich Nolle (1583-1626), Petrus Lauremberg (1585-1639), and Johann Heinrich Alsted $(1588-1638){ }^{262}$ It referred to a Christian universal science, which is also how Mögling understood it.

According to Mögling, this knowledge of oneself required a moral attitude. Humans were nothing without God, and, again like the brethren, they were to read His Word, to follow His commandments, and to love their neighbours like themselves. ${ }^{263}$ God's commands provided one's moral directions, determined one's being, and the signs of erudition were "a quiet and peaceful conscience, contempt of all pride (especially on the part of the lovers of themselves), compassion for the poor, love of God and one's neighbour, hatred of the world, yearning for the eternal life, and what more pious virtues there may be." 264 Note here the similarities with the pietist inclinations of Arndt and Andreae. ${ }^{265}$

This is reminiscent of the moral attitude Haslmayr had assumed in relation to knowledge of oneself. According to him, the "fools" want to know all things better than prophets and apostles, "but have not yet learned to read themselves; they want to rule and teach others, but have not yet learned to rule and know themselves after the four above-mentioned rules of holy true Christendom."266

261 Mögling seemed to have used "theosophy" and "pansophy" interchangeably. The two traditions were equally all-encompassing, and in both traditions the microcosm-macrocosm analogy played a pivotal role; see: Faivre, Theosophy, Imagination, Tradition, 9-10. For Peuckert, the two terms were interchangeable, and he also names Haslmayr a pansopher; see: Peuckert, Pansophie, $35^{2}$ ff.; idem, Das Rosenkreutz, 18, 103.

262 See, including on Mögling and pansophy: Kühlmann, "Pansophie," in TRE 25, 624-627. Cf. Hotson, Johann Heinrich Alsted.

263 Mögling [Theophilus Schweighart], Pandora, 10: "Derowegen folge den Brüdern/ such Gott am ersten/ quaerite primo regnum Dei, laß diß dein ergon und anfang in der Rhodostavrotischen Philosophi sein. Lise fleissig seine wort/ schreibs in dein herz/ sihe das du denselbigen ehrest und ihme gehorehest/ welches geschicht/ wann du deinen Nechsten liebest/ als dich selbst."

264 Idem, Speculum, 14: "[...] gedenck unnd glaub festiglich daß du summum humanae sapientiae in hac vita fastigium foeliciter attingirt, unnd deinem Kunstbegirigen Gemüth ein völliges genügen gethan hast/ das Zeichen deiner Erudition wirt seyn/ ein still ruhig Gewissen/ Verachtung alles Stolz/ sonderlich der philauti, Barmherzigkeit gegen den Armen/ Liebe Gottes/ und des Nächsten/ haß der Welt/ Sehnen nach dem ewigen Leben/ unnd was dergleichen Gottseelige Tugenden mehr seyn."

265 Cf. above, section 3.3.

266 Haslmayr, Theologia cabalistica, 45: “[...] die alle ding besser wollen wissen/ als der Geist der propheten und der Aposteln/ unnd haben doch noch nicht gelernet sich selbst zu lesen/ wöllen also andere regieren und lehren/ unnd haben sich noch selbsten nicht 
These four rules or "cabalistic main points" are: "I. To love our enemies. II. To abandon selfhood. III. To patiently endure slander inflicted upon us. IV. To refuse all honour offered to us." ${ }^{267}$ The term "Cabalism" here lost its original meaning and is now used in a moral context to advise others to take the path of humility in imitation of Christ - perhaps in addition to how he used it in his Answer, in a Christian and magical context. ${ }^{268}$

It was in this context that Mögling referred his reader to the medieval mystic Thomas à Kempis (1380-1471), and especially to his Opuscula. ${ }^{269}$ Thomas à Kempis stood in the tradition of the devotio moderna (modern devotion), which originated with the Dutch friar Geert Grote (1340-1384). ${ }^{270}$ The brothers and sisters of the devotio moderna aimed to reform Christian life and propagated humility and the Imitatio Christi. The movement quickly acquired popularity in the Dutch provinces and further afield, and soon special monasteries were built for their followers. Thomas à Kempis is believed to have expressed the aims of this tradition in his immensely popular On the Imitation of Christ, of which no fewer than one thousand manuscript copies were produced, and before 1650 the text was published in over 700 editions in various European and non-European languages. ${ }^{271}$ In his less famous Opuscula, which consists of several small texts and sermons, he described Christian rules of piety, including humility, poverty, and patience, and admonished his readers to follow Christ's example and to obey Christian rules. ${ }^{272}$

In the Opuscula, Mögling suggested, one finds "the entire art so impressively and beautifully" that if one follows them, one "is already more than half

lehren regieren und kennen nach den 4. Obgesetzten Regeln deß heiligen waren Christenthumbs."

267 Ibid., 41-42: "Den Unterscheid nun zu erkennen/ eines vollkommenen Menschens/ oder eins vollkommenen Viehs und trunckenen unvollkommenen Gestürns/ lunatischen Menschens/ und Antichristischen Scribenten solt ihr mich vernehmen/ihr Auditores und Söhn der ewigen wahre Lehr unnd Weißheiten GOttes in vier obangeregten Regeln/ unnd Hauptpuncten unsers Christenthumbs/ als unüberwindlichen Cabalae, welche seind: I. Unsere Feinde lieben. II. Eigens verlassen. III. Angethane Schmach gedultig leiden. III [sic] Anerbottene Ehre allenthalben vernichten. Das sind die Schlüssel zu der H. Gehaimen Scienz/ unnd Magnale Gottes/ der Cabalae, das ist der Christenheit Recht unnd Gerechtigkeit/ und ewiger Bund deß newen heiligen Gesatzes."

268 See above, p. $237 \mathrm{ff}$.

269 Thomas à Kempis, Opuscula aurea.

270 On the Devotio moderna, see:Van Engen, Sisters and Brothers of the Common Life:The Devotio Moderna and the World of the Latter Middle Ages.

271 On the editions, see: Von Habsburg, Catholic and Protestant Translations of the Imitatio Christi.

272 Thomas à Kempis, Opuscula aurea. 
a Rosicrucian, and will soon find the treasures of the microcosm and macrocosm." ${ }^{273}$ To be a Rosicrucian meant to live a Christian life in the tradition of the devotio moderna and proto-pietism, but also in the tradition of theosophy. According to Mögling, Thomas à Kempis was versed in the Rosicrucian ergon, and in his booklet "does nothing else but teach you to practice this ergon correctly and properly. For this reason his golden text can correctly and properly be named a source and origin of the dogmas of the Rosicrucians."274 In the way that the soul was more glorious than the body, so the ergon-which was described by "our dear and faithful brother" Thomas à Kempis-was more glorious than the parergon. ${ }^{275}$ To Mögling, Thomas à Kempis embodied the true Christian behaviour that was necessary for a renewed union with God and the heavenly Jerusalem that he believed to be the goal of the Rosicrucians.

These moral implications had their origin in Mögling's anthropology. Alongside the distinction between ergon and parergon, and body and soul, he distinguished two sets of eyes, that is, besides the physical eyes he identified also "two spiritual eyes." With one's spiritual right eye one could "see into eternity" and perceive the eternal and divine. With one's spiritual left eye one could perceive "time and creatures," and thus the natural world. An understanding of this distinction was also called the parergon, because it entailed knowledge of human anthropology, not of the divine. ${ }^{276}$ According to Mögling, these two eyes had to

273 Mögling [Theophilus Schweighart], Speculum, 10: “[...] betrachte die alte Theologische 2. Opuscula Thomae à Kempis vor anderthalb 10o. Jahren beschrieben/folge ihnen nach/ du hast hierinnen die ganze Kunst so stattlich/ unnd schön/ daß sie wol wert in Silber/ Golt und Edelgestein einzuhäfften/ und als den aller höchsten Schatz zubewahren/ kanst unnd thustu das/ so bistu schon mehr ein halber RosenCreuzer/ und werden sich die Magnalia macro-\& microcosmica bald finden." Cf. ibid., 20: "Ist aber einer der es Christlich und gutt meynt/ und ime das Ergon von Herzen gehet/ wil ich ime mein getrewen Rath geben. Er lasse sich ein geringes Gelt nit rewen und kauff bey den Buhführern das so offtgemelte köstliche Büchlein Thomae à Kempis, lese unnd widerlese solches zum öffteren/ schick seyn Leben so viel Menschlich und möglich darnach an/ists das ime von Herzen gehet/ wirt sich entweders schrifftlich oder mündtlich (wie im ersten Capitel gemeldet worden) bald ein Frater, oder dergleichen mit dem Parergon bey im finden."

274 Ibid., 12: "[...] wirstu solchen in obgemelten Büchlein D. Thomae à Kempis wytläuftig genug finden: Dann der Author im selbigen Buch/thut nichts anderst/ als daß er dich dieses Ergon recht und wol lehrt exercirn/kan also dieses seyn güldines scriptum, recht und wol ein fons \& origo dogmatum Rhodo stauroticorum genent werden."

275 Ibid., 18: "Nun merck/ so viel herrlicher (wie vorgemelt) die Seel ist als der Leyb/ so viel vortrefflicher ist dz obgesetzte Ergon, als dieses Nachwerck/ und wisse und gedencke fehlstu in dem ersten/ so komptu nimmermehr zu dem lesten/ merck auch wol was unser lieber getrewer Bruder à Kempis ferner setzt."

276 Ibid., 18: "Und hier ist zu mercken daß die geschaffene Seel deß Menschens hat zwey Geistliche Augen/ das rechte Aug ist die Müglichkeit zusehen in die Ewigkeit/ das lincke Aug 
work separately and not be engaged at the same time. ${ }^{277}$ One should first see with one's spiritual right eye into eternity, rise up to God and "know God your Creator and yourself." Thereafter humans should "descend," look with their spiritual left eye, and recognise the diversity in the perishable world, all aspects of nature, the elements, and the "mineral, vegetable, and animal" realms, and also, again, themselves, namely their bodily aspects. ${ }^{278}$ Human beings, therefore, were both natural and divine, because they had to use both spiritual eyes to study themselves. For Mögling, to see alternately with both eyes, to study both aspects of reality, to combine the ergon and the parergon, was "Rosicrucian pansophia." The ergon and parergon should be in harmony in order for humans "to acquire complete perfection in this life."279 Human beings thus had a double nature, which was intimately related to ethics and rules of behaviour.

For an understanding of the origins of this anthropology we must again turn to Weigel. In his Gnothi seauton and The Golden Grasp, Weigel had referred to two sets of eyes. According to his Gnothi seauton, one set of eyes was carnal and was shared with all animals, and another was intellectual or mental and was aimed at the highest, that is divine, knowledge: it could observe both God and the angels. Weigel added a third set, placed between the first and second types, which were the rational eyes that could study the arts and the sciences, ${ }^{280}$ but

zusehen in die zeit und Creaturen/ darinnen Underscheid zuerkennen/ was besser oder geringer/ und geliebter dem Leib leben zu geben und zuerhalten: hierinnen ist das Parergon."

277 Ibid., 18, 20: "Es mögen diese zwey Augen der Seelen des Menschens miteinander ihr Werck zugleich nit uben/ sonder soll die Seel mit dem rechten Aug in die Ewigkeit sehen/ so muß sich das lincke Aug aller seiner Werck verzeyhen/ das ist nicht nach den Creaturen sehen/ und sich halten als ober er todt sey: Soll aber das lincke Aug sein Werck uben nach der außwendigkeit/ das ist in die Zeit sehen/ und mit den Creaturen handlen/ so muß das rechte Aug gehindert werden in seiner beschawung (zuverstehen von dem Menschen) und Rhodostaurotosophischer Weiß zu experiren/ darüber nichts seeligers in der Welt."

278 Mögling [Theophilus Schweighart], Speculum, 18, 20: "Sihe erstlich mit dem ersten Aug in die Seeligkeit/ erkenn Gott deinen Schöpffer und dich selbers/ bitt ihn umb gnedigen beystand/ und verzeyhung deiner Sündt/ ist eins und das vornembste/ unnd must hier das lincke Aug zuhalten; Nachmalen steig von dem Berg herunder sehe mit dem lincken Aug (doch das das rechte den Vorzug behalte) in die zeit und Creaturen; Betrachte erstlich die Natur/ waß derselben möglich [...] darnach die Elementa/ wie sie dardurch operiren das sperma, als dann die drey underschiedliche Reich der Natur/minerale, vegetabile, animale, und darinnen entlich widerumb dich selbens/von dannen du wider auffsteigest zu Gott dem Allmächtigen deinem Schöpffer."

279 Mögling [Theophilus Schweighart], Pandora, 13: "Jetzt gib achtung/ wie selbige zugebrauchen/ damit auß dero concordantz du mögest endlich erlangen die volkommene perfection in disem leben."

280 Weigel, Gnothi seauton, 24: "Nun wollen wir auch vor vns nemen/ die innern Kräfften deß 
he especially emphasised the carnal and intellectual eyes. In The Golden Grasp, he linked these two sets of eyes to a number of corresponding twofold distinctions, such as between two objects, two kinds of wisdom, two lights, two Adams, and two faiths. ${ }^{281}$ Weigel, like Mögling, also distinguished between the left and right eye: the former sees internal powers while the latter is directed at external things. ${ }^{282}$

Mögling argued that by means of the ergon and the parergon, by reuniting one's soul with God, and by letting the "evil godless world die," one could allow the "heavenly Jerusalem" to be "reborn."283 This was a spiritual process. In Mögling's view, Jerusalem could rise anew even before Christ's Second Coming and His Judgement at the end of time. By means of an internal reformation it could be realised on earth. Preparing oneself for this was what Mögling named pansophia, the ergon, and the achievement thereof was "pansophical perfection." Here he clearly anticipated the views later expressed by Andreae, who was to argue that internally one could already inhabit the New Jerusalem while physically abiding still on earth. ${ }^{284}$

This view of the ergon and parergon also had apocalyptic significance. The internal rebirth of the heavenly Jerusalem, according to Mögling, was to take place during the Last Days, when the rays of God send the godless world into the final fire and, in the tradition of the philosophia perennis, divine wisdom increases:

[...] that from such brightly luminous flames, hardly any sparks remained, until this our concluding final time, through which the long-expected rise of the sole holy beatific gospel and the revelation of the Son of God finally expel such darkness, and the rays of the divine wisdom shine forth more

Menschens/ welche wir ordnen in drey Theil/ oder in ein dreyfaches Auge. Das erste ist/ oculus carnis, ein Auge deß Fleisches/ damit man ansihet/ die Welt vnd alles was auff die Küchen gehöret. Das ander ist/ oculus rationis, das Auge der Vernunfft/ damit man sihet/ vnd erweiset/ oder erfindet die Künste/ vnnd vollbringet alle vernünfftige Gewercke/ vnd Handwercke: Das dritte vnd öberste Auge im Menschen/ heisset oculus mentis seu intellectus, das Auge deß Verstandes/ damit man anschawet Gott vnd die Engel." Cf. ibid., $25 \mathrm{ff}$.

281 Weigel, Der Güldene Griff, ch. 6.

282 Idem, Gnothi seauton, 24.

283 Mögling [Theophilus Schweighart], Speculum, 13 (2): "[...] so viel ist auch derselben Perfection höher und grösser in acht zu nemmen/ dardurch wir Menschlicher Natur/ und Gebrächlichkeit enteussert/ unserem Archetypo Gott dem Allmächtigen widerumb seeliglich vereiniget/ der bösen Gottlosen Welt absterben/ und dem Himmlischen gebenedeyten Jerusalem newgeboren werden; diese ist die seeligste unnd beste Kunst/ so der Menschliche Verstandt mag apprehendieren."

284 See above, section 3.3. Cf. Mögling [Theophilus Schweighart], Speculum, 13 (2). 
and more and hopefully soon kindle the last fire for this godless world; and because the obdurate hearts of the humans having walked in error and in a dangerous labyrinth inspected mostly the parergon, because of this darkness they will not understand the eternal divine gleam of light. ${ }^{285}$

Mögling believed that the end was nigh. The title of his first tract, Pandora of the Sixth Age, referred to the seven ages of the world that were mentioned in biblical texts, as well as to the Rosicrucians' reference to this age in their Confessio. ${ }^{286}$ Presumably, Mögling considered his time to be the sixth age, which was to be followed, as claimed by Augustine, by a seventh age of the eternal Sabbath. The inner reformation was to prepare one for the New Jerusalem, and those unworthy of it would not receive God's light. According to Mögling, the biblical figure Elijah would return to the world to reveal all secrets and original wisdom once known to Adam and his descendants, resulting in a final apocalyptic outpouring of original knowledge. ${ }^{287}$

The "true philosophy" of the Rosicrucians would be at the expense of established academics, so that also for Mögling theosophy was complemented by academic reform. Acknowledging the need to reform academia and its teachers, Mögling believed that it was his task to cure "their uncouth Stagirite humours" through "pills of truth." 288 At places of learning, he commented,

285 Mögling [Theophilus Schweighart], Speculum, 16: “[...] daß von solchen helleuchtenden Flammen/ kaum etliche Füncklein verblieben/ biß zu dieser unser zu endlauffender letzten Zeit/ dadurch lang erwarteten Auffgang deß Heyligen enig Seeligmachenden Evangelij/ und offenbahrung deß Sohns Gottes/ entlich solche Finsternuß vertriben/ die Stralen Göttlicher Weißheit je mehr und mehr herfür leuchten/ unnd verhoffentlich der Gottlosen Welt bald den letzten Brandt anzünden werden/ unnd derhalben die verstockte Herzen der Menschen im Irthumb und gefährlichen Labyrinth gewandelt/ mehrertheyls das Parergon angesehen/ und vor deß selbige Finsternuß/ des ewigen Göttlichen Liechtes Schein nit begreiffen mögen."

286 On this, see above, p. 58 .

287 Mögling [Theophilus Schweighart], Speculum, 16-17: "Wer dieses hat/ hat alles in ihm/ dann er Iehouah unser Gott ist Allmächtig/ unnd eine unerschröpffliche Quell alles guten/ wer ihm vor dem Fall gehorcht/ darff vor Weißheit nicht sorgen/gleich wie Adam hieran kein mangel erlitten/ und auch zweyffels frey/ wir seine Nochkomnen gleicher gestalt hiemit begabt weren/ wo nicht die so offt verfluchte Teuffelische Philauti gedachte unsere Vorältern Diabolo insidias struente hindergangen/ und dieses Göttlichen ewigen Lichtscheins (Leyder Gott erbarms) dermassen obfuscirt, daß von solchen helleuchtenden Flammen/ kaum etliche Füncklein verblieben/ biß zu dieser unser zu endlauffender letzsten Zeit [...]. Wir sprich ich sollen die lange Zeit verborgene Füncklein Göttlicher Allmacht/ unnd so viel hundert Jahr hero versteckte Pansophische Concordanzen mit ernst/ und Christlichem Eyffer herfür süchen."

288 Mögling [Theophilus Schweighart], Pandora 3: "Hab ich nicht unterlassen sollen noch 
there could be found nothing but "useless quarrel" and the scholastic practice of useless repetitions of disputations based on Aristotelian and Platonic texts. ${ }^{289}$ Copying the Confessio verbatim, Mögling borrowed its explanation that Rosicrucian theosophy should replace these pagan practices so that the students could awake "from the sleep of sins, and may meet the new rising sun or beneficial Elijah with an open heart, bare-headed and barefoot, happy and jubilant." ${ }^{290}$ True knowledge was possible shortly before the end and while still living, while also academia was to be cured and reformed. For Mögling, theosophy, the reform of academia, and the apocalyptic preparations for the New Jerusalem were interconnected.

\subsection{Concluding Remarks}

All of the commentators discussed in this chapter set themselves the task of explaining or clarifying the Rosicrucian manifestos, and they did so by coopting the texts into their respective worldviews. Each interpreted the manifestos in their own way, according to their own background, and this resulted in a variety of readings, ranging from an emphasis on alchemy or medicine to readings based on theosophy. The early response was therefore highly eclectic.

Some emphasised the Paracelsian inspiration of the Rosicrucian manifestos and understood the brethren of the fraternity to be Paracelsians. The anonymous authors hidden behind the initials G.A.D. and C.H.C. discussed Paracelsian medicine and alchemy, of course irrespective of whether these had their origin

konnen/ solchen vor der Welt subtilen und eygensinnigen köpffen [von Gottlosen Weltkindern]/ ein Electuarium Rhodostauroticum zu componiren/ und deroselbe grobe stagiritische humores durch gegenwertige pilulas veritatis ausser dem Haupt zu purgieren."

289 Idem, Speculum, 17: "ziehe auff Universiteten/Academias, Gymnasia und Schulen/ wo du wilt/ finstu nichts anders/ als mehrertheyls unnütze vergebliche Zänck/ ohnnötige quaestiones von dem sensu dieses oder jenes Aristotelischen/ Platonischen oder eines andern Philosophi Texts viel hundert disputationes."

290 Ibid., 4: "[ich] kan doch auß christlicher Liebe gegen dem Nechsten [...] nit umbgehen/ meine vor der zeit umb gleicher Ursach willen in offentlichen Truck gegebene Pandoram mit Schematismis weytlaufftiger zuerklären/ das so fielfältig begerte Collegium/ Losament oder Behausung/ der Hochlöb. Rodostaurotischen Brüderschafft/ beneben deroselben wahren philosophy/ den fidelibus Pansophiae studiosis zuentdecken, damit sie doch einmal vom Schlaff der Sünden erweckt/ der new auffgehenden Sonnen und salutifero Heliae, mit eröffnetem Herzen/ entblöstem Haupt/ und nackenden Füssen/ frölich und freudig möchten entgegen gehen." Cf. Confessio, 56 : "postquam venenati et soporiferi calicis crapulam edormiverit Mundus; atque manet exorienti Soli apertis pectoribus, detectis capitibus, amotis calceis, laetus jubilansque; obviam processerit." See above, p. 9o. 
in authentic or spurious texts. Both understood Paracelsian philosophy as the restoration of original Adamic wisdom. While in the early days of Paracelsianism, Paracelsus was primarily understood as a physician, he was now heralded for his philosophical contributions and expressions of divine wisdom, presumably thanks to the manifestos. As a result, he came to be seen as a precursor of the Rosicrucians. Haslmayr in turn related Paracelsianism to theosophy, and claimed that the theosopher Weigel had been an advocate of the "Theophrastia Sancta."291 His similarities with Weigel are evident, and cover not just the emphasis on knowledge of oneself, but also the shared admiration for Paracelsus.

In his Answer, Haslmayr understood the manifestos as announcing the end of the world, which rendered a general reformation superfluous. As the first public response to the Rosicrucian texts, published numerous times, one might have expected the Answer to have shown a marked influence on these later authors. This seems not to have been the case, although Haslmayr was not alone in neglecting the theme of a general reformation. Maier, who had understood the Rosicrucians as alchemists and physicians, specifically rejected their call for a reformation, believing that it contradicted orthodox Lutheranism. Maier admired the brethren and discussed the Rosicrucian writings in several of his publications, but he only supported those ideas he believed were compatible with the Lutheran confession.

Other readers of the manifestos understood the Rosicrucians' reformation in a limited sense, namely in relation to apocalyptic expectations or as a reform of medicine and the arts, of man, or of divinity — thereby viewing it as a particular reformation.

The elements of the Rosicrucian manifestos on which G.A.D., C.H.C., and the author of the anonymous Preface elaborated were unorthodox, as they expected a return of Adamic wisdom and divine illumination. Such beliefs were part of the Rosicrucian general reformation, but these three authors took final illumination to indicate a period of full enlightenment, not an age of general reform.

C.H.C., however, combined this with the hope for a limited reformation of the arts and sciences, which was shared by Julianus and by Mögling. Their reformation of knowledge implied that more was to be expected than perfect knowledge granted by God, and that not God, but human agency could and should change and reform the world.

291 Gilly, "Theophrastia Sancta," 177-178. 
For Julianus, as for Mögling, such an external reformation was to be complemented by a personal, mystical union with God. For Mögling, as in the manifestos, the development of God's plan and the judgement of the state of contemporary learning provided the framework and defined the need for the change he championed. Evidently, if humans were able to unite with God, they were not only illuminated in a limited sense by Scripture, but could be illuminated also by God; they were no longer sinful and corrupt, but had become worthy of 'receiving' God. I.B.P. and Mögling went so far as to suggest that humans could acquire complete knowledge of the Creator. Julianus, I.B.P., and Mögling exhorted their readers to unite with the divine, so that not only human beings but also the divine itself would be interpreted anew as it found its seat within human beings. With this interpretation, they subsumed the message from the manifestos into the broader movement of theosophy. In so doing, they provided the Rosicrucian reformation divini et humani with a new significance; the "divine" was now an internal reality. In this sense, these authors were not only inspired by the manifestos, but also by the tradition of theosophy, and it may be concluded that particularly the works of Weigel had an influence on these authors, especially on Mögling.

Thus the elements of the Rosicrucian manifestos that these authors highlighted, and the traditions with which Rosicrucianism came to be combined, excited hope. Like many others, the authors of the anonymous replies, Julianus, and Mögling all felt the need to posit an alternative to the traditional Aristotelian and Galenic worldview of the scholastics and in opposition to Lutheran orthodoxy. The idea of reform was preconditional for most of their alternative worldviews, but the details of reform were not elaborated. 